\title{
Waste Heat Recovery and Recycling in Thermal Separation Processes: Distillation, Multi-Effect Evaporation (MEE) and Crystallization Processes
}

\author{
Final Technical Report
}

Award Number: DE-EE0003479

Project Period: August 16, 2010 to December 31, 2011

\section{Recipient Organization}

FMC Corporation

26 Miles West of Green River

Green River, WY 82935

\section{Business Contact}

Mr. Aaron Reichl

26 Miles West of Green River

Green River, WY 82935

Tel: 1-307-872-2581 Fax: 1-307-872-2548

E-mail:aaron.reichl@fmc.com

\section{Technical Contact}

Dr. Emmanuel Dada

1916 Lake Landing Drive

League City, TX 77573

Tel: 215-850-1883 Fax: 281-549-4223

E-mail: emmanuel.dada@ymail.com

\author{
Partners \\ E3Tec Service, LLC \\ 11865 Tall Timber Drive \\ Clarksville, MD 21209 \\ Congressional District: MD-007 \\ and \\ ChemResearch Engineering (CRE), LLC \\ 15515 North Platte Drive \\ Bowie, MD 20716 \\ Congressional District: MD-005
}

October 2012 


\section{Acknowledgment and Disclaimer}

Acknowledgment: This report is based upon work supported by the U. S. Department of Energy under Award No. DE-EE0003479.

Disclaimer: This report was prepared as an account of work sponsored by an agency of the United States Government. Neither the United States Government, nor any agency thereof, nor any of their employees, makes any warranty, express or implied, or assumes any legal liability or responsibility for the accuracy, completeness, or usefulness of any information, apparatus, product, or process disclosed, or represents that its use would not infringe privately owned rights. Reference herein to any specific commercial product, process, or service by trade name, trademark, manufacturer, or otherwise does not necessarily constitute or imply its endorsement, recommendation, or favoring by the United States Government or any agency thereof. Any findings, opinions, and conclusions or recommendations expressed in this report are those of the authors and do not necessarily reflect those of the United States Government or any agency thereof.

Document Availability: Reports are available free via the U.S. Department of Energy (DOE) Information Bridge Website: http://www.osti.gov/bridge

Reports are available to DOE employees, DOE contractors, Energy Technology Data Exchange (ETDE) representatives, and Informational Nuclear Information System (INIS) representatives from the following source:

Office of Scientific and Technical Information

P.O. Box 62

Oak Ridge, TN 37831

Tel: (865) 576-8401

FAX: (865) 576-5728

E-mail: reports@osti.gov

Website: http://www.osti.gov/contract.html 
1. Title Page

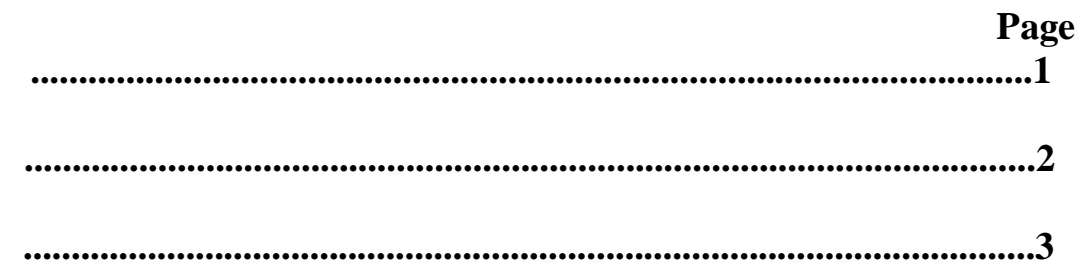

3. Table of Contents

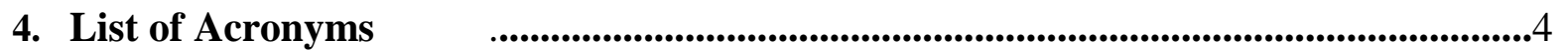

5. List of Figures $\quad$..........................................................................................................5

6. List of Tables

7. Executive Summary $\quad$. .........................................................................................................

8. Introduction

9. Background

10. Potential Benefits Assessment

11. Identification and Characterization of Working Fluid Pair for High-Temperature Heat Pumps $\quad$........................................................................................................22

12. Systems Analysis of Distillation and TEE Processes $\quad$............................................................28

13. Conceptual Design of Enhanced Heat Transfer Equipment $\quad$................38

14. Conceptual Design of Heat Transfer Device for Thermally Active Trays and Packing ......53

15. Commercialization Plan

16. Accomplishments $\quad$................................................................................................62

17. Conclusions $\quad$......................................................................................................63

18. Recommendations $\quad$...........................................................................................64

19. References/Bibliography 


\section{List of Acronyms}

[BMIm][BF4]: 1-Butyl Imidazolium tetrafluoro borate

[BMIm][Br]: 1-Butyl 3-Methyl Imidazolium bromide

BTX: benzene-toluene-xylene

C3/C4 : Refining propane/butane fractionation

HE: Heat Exhanger

HP: Heat Pump

MEE: Multi-Effect Evaporation

TBD : To Be Determined

TEGDME : Triethylene Glycol Dimethyl Ether

TFE : Trifluoroethanol

TEE: Triple Effect Evaporation 


\section{List of Figures}

\section{Task 1}

Page

Figure 1: Process flow schematic of a Conventional Hydrogen Peroxide Production

Figure 2: Process flow schematic of a waste-heat powered absorption heat pump of Conventional Hydrogen Peroxide Production

Task 3

Figure 3A: 1 ASPEN Process Flow Diagram of MEE Benchmark

Figure 3A:2 Process Flow Diagram of Soda Ash Triple Effect Evaporation - Closed Cycle Thermal Heat Pump

Figure 3B:1 ASPEN+ Flow Sheet for the Benchmark H2O2

Figure 3B:2 Process Flow Diagram for the combined Heat Pump for H2O2

\section{Task 4}

Figure 1. Process Flow Diagram of Hydrogen Peroxide Distillation

Figure 2. Process Flow Diagram of Soda Ash Triple Effect Evaporation - Open Cycle Thermal Heat Pump

Figure 3. Enhanced Tubes and Tube Inserts

51

Figure 4. Shell and coil heat exchanger

52

Figure 5. Section and elemental views of brazed aluminum heat exchanger

\section{Task 5}

Figure 1. PFD of H2O2 distillation with vapor feed equipped with thermal heat pump 


\section{List of Tables}

Task 1

Page

Table 1: Soda Ash Industry Energy Analysis 13

Table 2 Distillation energy consumption and estimate of potential energy savings 17

Table 3: MEE energy consumption and energy savings $\quad 17$

Table 5 Major Pollutants in the Chemical Industry 18

Table 6: Energy Usage Distribution in the Distillation Processes 19

Table 7: Reduction in Environmental Pollutants in the Distillation Processes 19

Table 8: Energy Usage Distribution in the MEE Processes 19

Table 9: Reduction in Environmental Pollutants in the MEE Processes 20

Table 10: Equivalent Water Savings in Distillation Processes 20

Table 11: Equivalent Water Savings in MEE Processes 21

\section{Task 2}

Table 1. Property requirements of working fluid pairs 23

Table 2A. Candidate working fluid pairs for industrial thermal heat pumps $\quad 24$

Table 2B: Identification of Working Fluids with typical operating temperatures 25

Table 3. Merit criteria of working fluids 27

\section{Task 3}

Table 3A:1a. MEE Benchmark 30

Table 3A:1b. MEE Benchmark Sensitivity to Higher Primary Steam Rate 30

Table 3A:2. MEE Performance for Heat Pump (LiNO3:KNO3:NaNO3 53:28:19) 30

Table 3A:3. MEE Performance for Heat Pump (LiNO3:KNO3:NaNO2 53:35:12) 31

Table 3B:1. H2O2 Benchmark 36

Table 3B:2. H2O2 Performance for Heat Pump (TFE-DMETEG) 36

Table 3B:3. H2O2 Performance for Heat Pump (Ammonia-Water) 36

\section{Task 4}

Table 1. Hydrogen Peroxide Distillation Process Parameters 43

Table 2. Hydrogen Peroxide Distillation Heat Exchanger Duty 44

Table 3. Hydrogen Peroxide Heat Exchanger Design Specifications 45

Table 4. Triple Effect Open Cycle Process Parameters 46

Table 5. Triple Effect Open Cycle Heat Exchanger Duty 47

Table 6. Triple Effect Open Cycle Heat Exchanger Design Specifications 47

Table 7. Heat Pump Performance Analysis of Heat Transfer Equipment 48

\section{Task 6}

Table 6.1 Estimated Payback Periods for the Heat Pump Waste Heat Recovery Systems 58

Table 6.1.1 Major Equipment Cost Estimate for the TEEOpen Cycle Thermal Heat Pump 59

Table 6.1.2 Major Equipment Cost Estimate for the H2O2 Distillation Cycle Thermal Heat Pump 60 


\section{Executive Summary}

Evaporation and crystallization are key thermal separation processes for concentrating and purifying inorganic and organic products with energy consumption over 1,000 trillion Btu/yr. This project focused on a challenging task of recovering low-temperature latent heat that can have a paradigm shift in the way thermal process units will be designed and operated to achieve high-energy efficiency and significantly reduce the carbon footprint as well as water footprint. Moreover, this project has evaluated the technical merits of waste-heat powered thermal heat pumps for recovery of latent heat from distillation, multi-effect evaporation (MEE), and crystallization processes and recycling into the process. The Project Team has estimated the potential energy, economics and environmental benefits with the focus on reduction in CO2 emissions that can be realized by 2020, assuming successful development and commercialization of the technology being developed. Specifically, with aggressive industry-wide applications of heat recovery and recycling with absorption heat pumps, energy savings of about 26.7 trillion Btu/yr have been estimated for distillation process. The direct environmental benefits of this project are the reduced emissions of combustible products. The estimated major reduction in environmental pollutants in the distillation processes is in CO2 emission equivalent to 3.5 billion lbs/year. Energy consumption associated with water supply and treatments can vary between 1,900 kWh and 23,700 kWh per million-gallon water depending on sources of natural waters [US DOE, 2006]. Successful implementation of this technology would significantly reduce the demand for cooling-tower waters, and thereby the use and discharge of water treatment chemicals.

The Project Team identified and characterized working fluid pairs for the moderate-temperature heat pump. For an MEE process, the two promising fluids are LiNO3+KNO3+NANO3 (53:28:19) and LiNO3+KNO3+NANO2(53:35:12). And for an $\mathrm{H} 2 \mathrm{O} 2$ distillation process, the two promising fluids are Trifluoroethanol (TFE) + Triethylene Glycol Dimethyl ether (DMETEG) and Ammonia+ Water. Thermophysical properties calculated by Aspen+ are reasonably accurate. Documentation of the installation of pilot-plants or full commercial units were not found in the literature for validating thermo-physical properties in an operating unit. Therefore, it is essential to install a pilot-scale unit to verify thermophysical properties of working fluid pairs and validate the overall efficiency of the thermal heat pump at temperatures typical of distillation processes. However, due to the long payback period for the TripleEffect Evaporation (TEE) process (three effect MEE applied to the soda ash process), further studies on the TEE system are not warranted unless there are significant future improvements to heat pump technology.

Detailed Aspen + analyses on the heat pump systems indicated that primary steam reduction between $16 \%$ and $45 \%$ may be achievable over the benchmark for the H2O2 system. Significant technical issues with the initial Task 3 systems analysis for the TEE were discovered through detailed work in later tasks. For the TEE open system, these issues were corrected. When this system failed to show economic justification, the TEE closed system was abandoned due to the fact that its savings would be less and its capital cost would be greater than the open system. In general, the feasible steam savings for TEE open system that is found to be reasonably applicable for TEE process we have considered for this project is less than $16 \%$. In the $\mathrm{H} 2 \mathrm{O} 2$ distillation process, compared to the benchmark, the savings in steam import are $44 \%$ and $43 \%$ for TFE+DMETEG and Ammonia + Water heat pumps, respectively. The steam/duty savings were for the same level production $(\sim 9,076 \mathrm{lb} / \mathrm{hr}, 71.2 \mathrm{wt} \% \mathrm{H} 2 \mathrm{O} 2)$ for the $\mathrm{H} 2 \mathrm{O} 2$ process. The TFE+DMETEG heat pump operates at lower pressure (40psia) and higher flow (538,354lb/hr) than the Ammonia + Water heat pump at 635 psia and 66,939lb/hr. Thus the ammonia-water heat pump system is more compact and preferable than the TFE-DMETEG heat pump. The ammonia-water heat pump is therefore recommended for the $\mathrm{H} 2 \mathrm{O} 2$ process.

The Project Team performed conceptual design of enhanced heat transfer equipment that includes twisted tubes, spirally fluted tubes, and compact heat exchangers for the TEE process. We have also completed the conceptual design for a heat-transfer device for thermally active distillation trays and packed columns. 
Furthermore, a rigorous analysis was performed to evaluate heat transfer enhancements and heat exchanger configurations using an excel-based algorithm for the heat transfer analysis of each of the heat transfer units for both the TEE and $\mathrm{H} 2 \mathrm{O} 2$ distillation systems. In addition, detailed heat exchanger specification data sheets were developed for the thermal heat pump system. The results showed that shelland-tube heat exchanger equipped with Twisted Tubes ${ }^{\circledR}$ with microfin on outside of tubes is ideally suited for thermal heat pumps. Alternatively, spirally indented tubes with microfins on outside would provide comparable heat transfer performance, but at a higher tube-side pressure drop. Thermal performance parameters were incorporated into the systems analysis of the integrated thermal heat pump and process unit. This approach provided design parameters close to optimum, where further optimization can be carried out in the next phase of designing a prototype unit. We noted that heat-integrated distillation columns have potentials for significant improvements of energy efficiency and further development should be considered. We developed new and improved design concepts for integrating heat transfer units within trays and packed columns. The heat transfer units can be fabricated using the state-of-the-art manufacturing techniques; however, innovative concepts of configurations are required for effective integration within trays and packed columns without adversely affecting the two-phase flows and equilibrium between vapor and liquid phases.

Based on the complex nature of the heat recovery system, we anticipated that capital costs could make investments financially unattractive where steam costs are low, especially where co-generation is involved. We believe that the enhanced heat transfer equipment has the potential to significantly improve the performance of TEE crystallizers, independent of the absorption heat-pump recovery system.

Where steam costs are high, more detailed design/cost engineering will be required to verify the economic viability of the technology. Due to the long payback period estimated for the TEE open system, further studies on the TEE system are not warranted unless there are significant future improvements to heat pump technology. For the $\mathrm{H} 2 \mathrm{O} 2$ distillation cycle heat pump waste heat recovery system, there were no significant process constraints and the estimated 5 years payback period is encouraging. We therefore recommend further developments of application of the thermal heat pump in the $\mathrm{H} 2 \mathrm{O} 2$ distillation process with the focus on the technical and economic viability of heat exchangers equipped with the state-of-theart enhancements. This will require additional funding for a prototype unit to validate enhanced thermal performances of heat transfer equipment, evaluate the fouling characteristics in field testing, and remove the uncertainty factors included in the estimated payback period for the $\mathrm{H} 2 \mathrm{O} 2$ distillation system. 


\section{Introduction}

The overall objective of this Stage 2 Concept Definition project is to determine the technical merits of waste-heat powered thermal heat pumps for recovery of latent heat from distillation, multi-effect evaporation, and crystallization processes and recycle into the process. The FMC Team envisaged that successful development of waste-heat powered thermal heat pump technology will have transformational impact on energy efficiency improvements greater than 20\% in thermal separation processes; distillation, multi-effect evaporation (MEE) and crystallization processes. Due to inherent nature of these processes, large amount of latent heat is rejected to the atmosphere as heated air in air-cooled condensers or in the form of water vapor from cooling towers in water-cooled condensers. The FMC Team pursued recovering this latent heat using heat powered thermal heat pump and recycling into the process. This is a highly technologically and economically challenging task. Consequently, the Team focused on key technical issues towards achieving tangible energy reduction.

The project objective was achieved by focusing on the following specific aims that are crucial to the development of waste heat-powered thermal heat pumps.

- Identify and characterize working-fluid pairs for high temperature industrial applications typical of thermal separation processes;

- Identify key developments required for the new and improved design of heat-transfer equipment that will significantly improves the techno-economic viability of waste-heat powered thermal heat pumps; and

- Develop design concepts for thermally active trays or packed columns for recycling the latent heat into the distillation process of distributed reboilers and reflux condensers. 


\section{Background}

This project was a direct response to the FOA Topic 2: Energy Intensive Processes: C. Waste heat minimization and recovery. While the industry has been pursuing recovery of high-temperature waste heat from fired heaters and boilers, this project focuses on a challenging task of recovering lowtemperature latent heat that can have a paradigm shift in the way thermal process units will be designed and operated to achieve high-energy efficiency and significantly reduce the Carbon Footprint. Thermal processes of distillation, multi-effect evaporation (MEE), and crystallization are the workhorses for separation, purifying, and concentrating organic as well as inorganic products. Distillation dominates separations in the chemical, petrochemical, and refining processes and is expected to continue to dominate in the future. In the U.S. alone, over 40,000 distillation columns are in operation, handling 90$95 \%$ of all separations. It has been stated that the total energy consumed by distillation (2,400 trillion $\mathrm{Btu} / \mathrm{yr}$ ) is about $3 \%$ of the energy consumed in the U.S. Evaporation and crystallization are key thermal separation processes for concentrating and purifying inorganic and organic products. They are second only to distillation in their consumption of energy, which is greater than 660 trillion Btu/yr. By way of the nature of these thermal separation processes, large amount of latent heat is rejected into the atmosphere or cooling water.

The project focused on waste-heat powered thermal heat pumps for recovering the latent heat and upgrading for recycling into the process for the three thermal separations processes, distillation, multieffect evaporation (MEE) and crystallization that are of major significance to FMC and the process industry in general. Please note that TEE (Triple Effect Evaporation) and MEE (Multiple Effect Evaporation) are interchangeably used in this report with TEE being a more specific use of the term MEE.

\section{Qualifications and Past Experiences of Project Team Members}

The project was conducted by a multidisciplinary team comprising FMC Corporation; E3Tec Service, LLC; and Chemical Research Engineering, LLC and led by FMC. Dr. Emmanuel Dada was the Principal Investigator (PI) of this project, with Dr. C.B. Panchal of E3Tec Service, LLC as Co-PI.

\section{Key Personnel:}

Dr. E. Dada (PI, Consultant to FMC): Ph.D. Chem. Eng., Lehigh University, 1989. His major responsibilities are to integrate research tasks at FMC, E3Tec Service, and ChemResearch Engineering; and plan outreach activities for technology transfer and commercialization. Prior to joining FMC in 1995, he worked at Rohm and Haas Company from 1989 to 1994. Dr. Dada successful led FMC's efforts as the co-PI in the DOE-funded \$1.5-million, 5-year (2002 to 2007) project to develop (jointly with Stevens Institute) a novel microchannel reactor design for the production of hydrogen peroxide by the direct combination of hydrogen and oxygen, with significant results. Over the years, he has designed conceptual processes, provided data for new product formulation, guided vendor testing of a potential new product, and screened process alternatives for a critical environmental control project. In the last eight years, he has evaluated alternative routes to production of $\mathrm{H}_{2} \mathrm{O}_{2}$ and carried out comparative profitability analysis on different technologies to make $\mathrm{H}_{2} \mathrm{O}_{2}$. Dr. Dada has worked with FMC engineers to update the capital and operating costs for direct combination technology, over-the-fence, and megaplant manufacture of $\mathrm{H}_{2} \mathrm{O}_{2}$. Dr. Dada is the key FMC engineer in establishing collaborative initiatives with outside companies interested in the generation of $\mathrm{H}_{2}$ gas and in the supply of the catalyst for production of $\mathrm{H}_{2} \mathrm{O}_{2}$. He has published 20 papers, 4 patents, and 1 provisional patent application, and he has 2 invention disclosures. As the PI, Dr. Dada led the project. 
Dr. C. Panchal (Co-PI, E3Tec Service, LLC): Dr. Panchal is a founder of E3Tec Service, LLC. His major responsibilities in this project are to support FMC to manage the project and work on the three aspects of the project: 1) thermal heat pump; 2) enhanced MEE evaporators; and 3) monitoring-based fouling mitigation. He will be assisted by an associate at E3Tec Service, Company. After serving for more than 25 years at Argonne National Laboratory, he took an early retirement in 2006 from Argonne to better serve the industry. Dr. Panchal has more than 25 years of heat/mass transfer research experience at Argonne with the focus on fouling mitigation, heat transfer enhancement, and compact heat exchangers. He helped to establish and manage the thermal science and fouling research at Argonne, making it nationally and internationally recognized in this field. He designed pilot-scale test facilities, conducted laboratory and field tests, and developed new measurement sensors. As a consultant to Energy Concepts Co. for six years (2000-2006), he pursued waste-heat powered ammonia absorption refrigeration systems in petroleum refining and petrochemical industry.

Prof. Luke E. K. Achenie (Consultant to ChemResearch Engineering, LLC): Prof., Chem. Eng., Virginia Tech., and Consultant to ChemResearch Engineering (CRE), LLC. Ph.D. Chem. Eng., Carnegie Mellon University, 1988, M.A.M., Applied Mathematics, Carnegie Mellon University, 1984, M.S. Eng. Science, Northwestern University, 1982, B.S. Chem. Eng., MIT, 1981. Dr. Achenie has considerable experience in both industry and academia having worked with Shell Petroleum Development Company, Houston, Texas as an Associate Research Engineer from 1988 to 1991 before accepting a faculty position with University of Connecticut in 1991. He is currently Professor of Chemical Engineering at Virginia Polytechnic and State University (Virginia Tech). His expertise is in mathematical programming (with applications to process design and optimization), computer aided molecular design, process modeling, interval analysis based global optimization, fuel-cell modeling and bioinformatics. He has published over 100 papers, 2 books, contributed to 8 book chapters, and edited a Journal Issue of AER, 2003.

Aaron Reichl (Management Sponsor, FMC):Director of Technology and Business Development, Alkali Chemicals Division, FMC Corporation. B.S. Chem. Eng., MIT, 1996. His major responsibilities are management of R\&D activities, new process development, major expansion technology and design, new business opportunity analysis, and long term technology planning and coordination. Aaron has worked for the FMC Akali Chemicals Division since 1996 in various roles including process engineering and design, production supervision and technical management. Aaron has made major technical contributions to key soda ash manufacturing improvements over the past several years including several incremental expansions, coal boiler emission improvements (SO2 and NOx), development of a system to process high impurity alkali streams, co-generation improvements, and various environmental improvement projects. In his various roles, Aaron has demonstrated the ability to champion major process improvement efforts and has been successful in gaining the support for many multi-million dollar capital projects.

Chris Thomas (Senior Process Engineer, FMC): Chris Thomas is a Senior Process Engineer/ New Technology, Alkali Chemicals Division, FMC Corporation. B.S. Chem. Eng., Kansas State University, 1996. His major responsibilities are tracking of FMC and external Intellectual Property, technical support of mergers and acquisitions, process development, and mentoring for newly hired engineers. Chris has worked for the FMC Alkali Chemicals Division since 2005 in various roles including process engineering and design. Chris has made significant technical contributions to key soda ash manufacturing improvements over the past several years including completing the detailed process design on a multimillion dollar project and coordinating the technical efforts for the start-up of two major processing units. Prior to FMC, Chris had various roles within the Oil \& Gas as well as Inorganic Chemical industries. 


\section{Task 1: Potential Benefits Assessment}

The project team has estimated the potential energy benefits, market penetration, economic benefits, environmental benefits with the focus on reduction in $\mathrm{CO} 2$ emissions and market benefits that can be realized in year 2020, assuming successful development and commercialization of the technology being developed. Some of the details are included in this report.

\subsection{Soda Ash Energy Analysis Based on Initial Assumptions}

From Table 1, based on initial assumptions, the annual production of soda ash in the US in 2009 was 10.9 million metric tons out of which triple effect constitutes $35 \%$ - $45 \%$ of the industry capacity. And the energy utility distribution of the $5.5 \mathrm{MBtu} /$ tone consumed in the soda ash industry is about $65 \%$ coal, $30 \%$ natural gas, and $5 \%$ purchased electricity out of which $40-50 \%$ of this goes to the triple effect heating (for those facilities that use triple effects). We assumed an overall energy reduction of $10 \%$ when the steam from the last effect is recovered. With this assumption, about 1.5 trillion Btu/year of energy savings can be realized with 20\% market penetration by 2020. 
Table 1: Soda Ash Industry Energy Analysis

\begin{tabular}{|c|c|c|c|}
\hline Year & 2009 & 2020 & \\
\hline Production, Thousand Metric Tons & 10900 & 13553 & \\
\hline Growth Rate, \%/yr & 2 & & \\
\hline Assumed Energy Reduction & & $10 \%$ & \\
\hline Assumed Market Penetration & & $20 \%$ & \\
\hline $\begin{array}{l}\text { Total Energy Consumption, Trillion } \\
\text { Btu }\end{array}$ & & 74.7 & \\
\hline Total Energy Savings, Trillion Btu & & 1.5 & \\
\hline Total Energy savings, \$ million & & 7.2 & \\
\hline & $\%$ & Energy, MMBtu/short ton & Energy, MMBtu/M ton \\
\hline Coal & 65 & 3.25 & 3.58 \\
\hline Natural Gas & 30 & 1.5 & 1.65 \\
\hline Purchased Electricity & 5 & 0.25 & 0.28 \\
\hline Total & 100 & 5.00 & 5.51 \\
\hline Assumed Energy reduction & & $10 \%$ & $\begin{array}{l}\text { (From preliminary } \\
\text { analysis based on } \\
\text { published Soda Ash data.) }\end{array}$ \\
\hline Assumed cost of energy & & 4.82 & \$/MMBtu \\
\hline Assumed market penetration, 2020 & & $20 \%$ & \\
\hline
\end{tabular}

Source of Soda Ash production: http://minerals.usgs.gov/minerals/pubs/commodity/soda_ash/mcs-2010sodaa.pdf

\subsubsection{Energy-Efficiency Improvements of Distillation in Hydrogen Peroxide}

Figure 1 shows a schematic of a conventional production of hydrogen peroxide. And Figure 2, shows an integrated $\mathrm{H} 2 \mathrm{O} 2$ distillation process with an absorption thermal heat pump system. As presented in Figures 3 and 4, the consumption of steam is reduced from $2.07 \mathrm{~kg}$ steam/lb of $\mathrm{H} 2 \mathrm{O} 2$ in the conventional process to about $1.29 \mathrm{~kg}$ steam/lb of $\mathrm{H} 2 \mathrm{O} 2$, a $37 \%$ savings. Similarly, the overall energy usage is reduced from 28.0 MBtu/hr in the conventional $\mathrm{H} 2 \mathrm{O} 2$ production to $17.4 \mathrm{MBtu} / \mathrm{hr}$, a 38\% savings. 


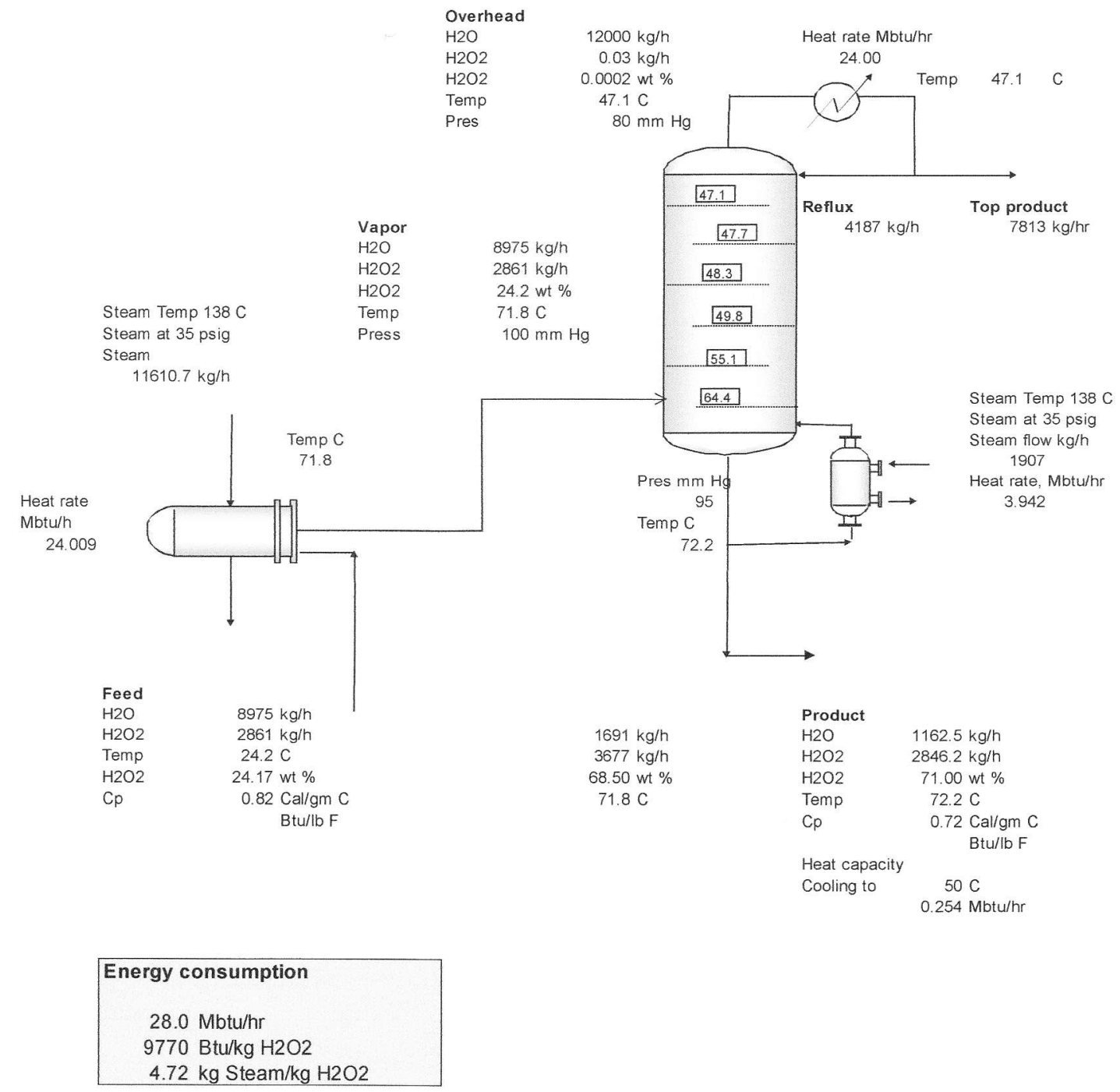

Figure 1: Process flow schematic of a Conventional Hydrogen Peroxide Production 


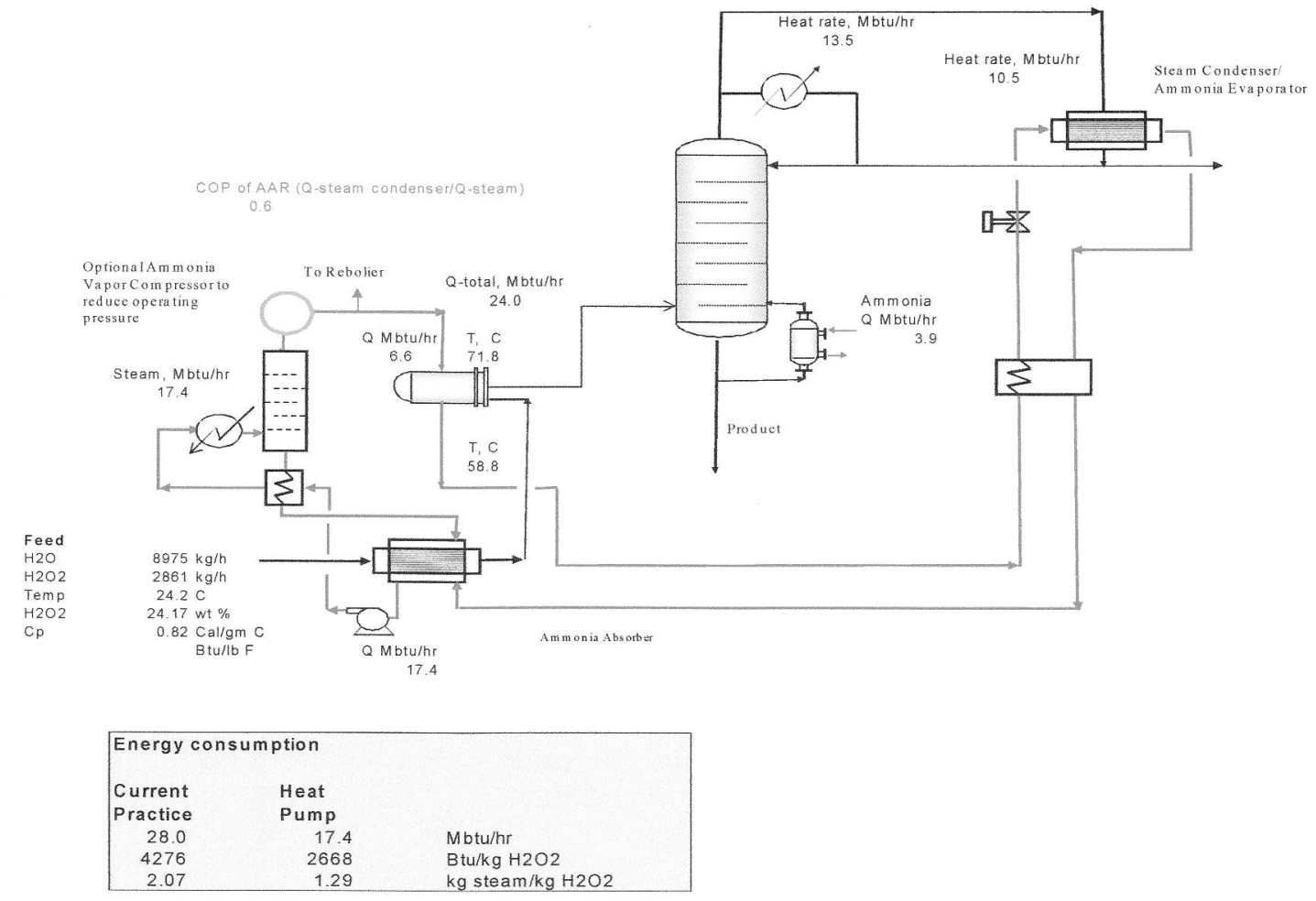

Figure 2: Process flow schematic of a waste-heat powered absorption heat pump of Conventional Hydrogen Peroxide Production 


\subsection{Energy Savings (Based on Initial Assumptions) Calculations for MEE and Distillation Processes}

Based on initial assumptions, energy savings in the distillation and MEE industries are estimated as shown in Tables 2 and 3, . These energy savings were originally calculated using the Energy Savings Tool at http://www.energetics.com/ies_tool/. The basic data for this tool were derived from Energy and Environmental Profile of the U.S. Chemical Industry, Office of the Industrial Technologies, May 2000; Separation Technologies Advances and Priorities [Humphrey et al. 1991]; and Energy Conservation in Distillation [Mix et al. 1978]. We updated the original calculations with our estimates for the soda ash industry shown in Table 1.

Distillation and MEE are the workhorses of the chemical industry, with consumption of about 1,000 trillion Btu/yr in distillation and more than 600 trillion Btu/yr in MEE and crystallization [Mix et al. 1978]. For the purpose of estimating energy savings, potential industry sectors represented by or closely related to this project have been used as the primary focus. Tables 2 and 3 present the separation processes with high potential of heat recovery and recycling included in the energy estimates.

As shown in Tables 2 and 3, a conservative estimate of tangible 2020 energy savings in distillation is 26.7 $\mathrm{Btu} / \mathrm{yr}$. With aggressive industry-wide applications of heat recovery and recycling with absorption heat pumps, energy savings of over 100 trillion Btu/yr are possible for distillation and MEE. Pulp, paper and paperboard mills account for $95 \%$ of energy use in the US paper and allied products industries, and $12 \%$ of total manufacturing energy use in the U.S [Nilsson et al., 1995].

Production of fuel ethanol is rapidly increasing in the U.S. to meet the national goal. There is significant energy saving potentials in production of fuel-grade ethanol. Energy savings for ethanol in Table 3.2 is based on present capacity. Production is expected to increase from the current level of about 12 billion gallons per year to 36 billion gallons per year by 2020 [EERE, 2007], most of this production is expected to be based on corn as feedstock. The net ethanol energy value of 1.34 (ratio of energy value of ethanol/energy consumed to produce ethanol) can be achieved only when the energy credit for coproducts is included [Shapouri et al., 2002]. The recovery of by-product DDGS requires MEE of thin stillage in dry grind processing and steep-water in wet milling, consuming an average of 13,360 Btu per gallon ethanol. The Estimator calculations are based on achieving energy savings of 1,275 Btu/gallon, based on which the Estimator shows energy savings of 45.9 trillion Btu/yr. Therefore, it is essential to develop an energy-efficient evaporation process for product recovery.

Many plants produce steam from high-temperature process streams (e.g., transfer-line heat exchangers in ethylene plants and recovery boiler in the pulp and paper industry) to operate distillation columns and MEE. Recovery and recycling of process heat may result in excess steam supply. This scenario discourages energy-efficiency measures, which would cause excess steam with no apparent use and force the plant to vent low-pressure steam. We will evaluate two options of Steam-Powered Refrigeration or Chilling and the Absorption Cycle Power Generation to make a choice on the best economic route for FMC site for heat recovery and recycling. 
Table 2. Distillation energy consumption and estimate of potential energy savings

\begin{tabular}{|c|c|c|c|c|c|}
\hline \multirow[t]{2}{*}{ Processes } & \multirow[t]{2}{*}{$\begin{array}{c}\text { Key Savings Basis } \\
\text { Assumption } \\
\text { Applied to Distillation } \\
\end{array}$} & \multirow[t]{2}{*}{$\begin{array}{c}\text { Market Penetration } \\
\text { Assumption }\end{array}$} & \multicolumn{2}{|c|}{$\begin{array}{l}\text { Distillation } \\
\text { Energy Use in } \\
2000 \\
\end{array}$} & $\begin{array}{l}\text { Energy } \\
\text { Savings } \\
\text { in } 2020 \\
\end{array}$ \\
\hline & & & $\begin{array}{l}\text { trillion } \\
\text { Btu/y }\end{array}$ & $\mathrm{Btu} / \mathrm{lb}$ & $\begin{array}{l}\text { trillion } \\
\text { Btu/y }\end{array}$ \\
\hline Hydrogen peroxide & $\begin{array}{l}40 \% \text { of steam } \\
\text { consumption }\end{array}$ & $\begin{array}{l}50 \% \text { of } \mathrm{H}_{2} \mathrm{O}_{2} \text { plants } \\
12 \% \text { market growth }\end{array}$ & 1.7 & 1,400 & 0.7 \\
\hline Aromatics & $\begin{array}{l}20 \% \text { of energy } \\
\text { consumption }\end{array}$ & $\begin{array}{l}20 \% \text { of BTX } \\
\text { market } \\
\text { Low } 2 \% \text { growth } \\
\text { rate }\end{array}$ & 90 & 590 & 1.9 \\
\hline Olefins & $\begin{array}{l}20 \% \text { of energy } \\
\text { consumption }\end{array}$ & $\begin{array}{l}20 \% \text { of } \mathrm{C} 2=\text { market } \\
\text { Low } 2 \% \text { growth } \\
\text { rate }\end{array}$ & 120 & 367 & 3.3 \\
\hline $\begin{array}{l}\text { Oxygenated } \\
\text { hydrocarbons }\end{array}$ & $\begin{array}{l}40 \% \text { of steam } \\
\text { consumption }\end{array}$ & $\begin{array}{l}20 \% \text { of all } \\
\text { distillation } \\
\text { Low } 2 \% \text { growth } \\
\text { rate }\end{array}$ & 100 & 2,169 & 14.5 \\
\hline $\begin{array}{l}\text { Refining - C3/C4 } \\
\text { fractionation }\end{array}$ & $\begin{array}{l}20 \% \text { of energy } \\
\text { consumption }\end{array}$ & $\begin{array}{l}20 \% \text { of distillations } \\
\text { Zero growth rate }\end{array}$ & 220 & 924 & 6.23 \\
\hline
\end{tabular}

Table 3 MEE energy consumption and energy savings

\begin{tabular}{|l|l|l|r|r|r|}
\hline & \multicolumn{1}{|c|}{$\begin{array}{l}\text { Key Savings Basis } \\
\text { Assumption }\end{array}$} & \multicolumn{1}{c|}{$\begin{array}{c}\text { Market Penetration } \\
\text { Assumption }\end{array}$} & \multicolumn{2}{c|}{$\begin{array}{c}\text { Estimated } \\
\text { Distillation Energy } \\
\text { Use } \\
\text { In 2000 }\end{array}$} & $\begin{array}{c}\text { Energy } \\
\text { Savings } \\
\text { In 2020 }\end{array}$ \\
\hline & \multicolumn{1}{|c|}{$\begin{array}{c}\text { trillion } \\
\text { Btu/year }\end{array}$} & Btu/lb & $\begin{array}{c}\text { trillion } \\
\text { Btu/yr }\end{array}$ \\
\hline Soda Ash & $\begin{array}{l}10 \% \text { of energy } \\
\text { consumption }\end{array}$ & $20 \%$ market growth & 75 & 2,505 & 1.5 \\
\hline $\begin{array}{l}\text { Black-liquor } \\
\text { concentrator }\end{array}$ & $\begin{array}{l}18 \% \text { - steam economy } \\
\text { increased by one effect }\end{array}$ & $\begin{array}{l}50 \% \text { of pulping } \\
\text { capacity }\end{array}$ & 129 & 96 & 9.5 \\
\hline Ethanol-DDGS & $\begin{array}{l}20 \% \text { - steam economy } \\
\text { increased by one effect }\end{array}$ & $\begin{array}{l}\text { 25\% of Ethanol } \\
\text { capacity } \\
\text { High market growth }\end{array}$ & 40 & 2,026 & 7.9 \\
\hline Caustic soda & $\begin{array}{l}40 \% \text { MEE steam } \\
\text { consumption }\end{array}$ & $\begin{array}{l}\text { 50\% of NaOH capacity } \\
\text { Low market growth }\end{array}$ & 41 & 1,788 & 4.0 \\
\hline
\end{tabular}




\subsubsection{Economics}

As detailed in the original proposal, the industry-wide energy savings benefit associated with this project based on initial assumptions, exceeds $\$ 290$ million/yr at the energy cost of $\$ 4$.82/MMBtu assumed by the IES Energy Estimator. When steam has multiple uses, this price may be justified. However, when natural gas is used directly or via steam production, energy costs at the current rate would be much higher. FMC has an economic incentive to reduce energy costs, as indicated by the surcharge (production plus shipping) on hydrogen peroxide. Other FMC plants also face a similar uncertainty of future energy costs. Therefore, FMC is interested in investing in technologies with high probability of improving the energy efficiency of two major separation processes (distillation and MEE) in FMC plants. The FMC's energy incentive is typical of the process industry, where distillation and MEE represent the major energy consuming processes.

Installation of high-performance heat exchangers for heat recovery and absorption heat pumps can be readily accomplished during normal turnaround. Therefore, market penetration should not be difficult as part of a routine retrofit in the chemical and refining industries.

\subsubsection{Environmental Benefits}

The main direct environmental benefits for this project are the reduced emissions of combustible products. Tables 5, 6, and 7 are from Energy and Environmental Profile of the U.S. Chemical Industry, Energetics Inc., Columbia, MD, May 2000 and Energy and Environmental Profile of the U.S. Petroleum Refining Industry, Energetics, Inc., Columbia, MD, and December 1998. From these tables, the reduction in environmental pollutants in the distillation processes is estimated as shown in Table 7. The major reduction is in $\mathrm{CO} 2$ emission equivalent to 3.5 billion lbs/year.

Table 5 Major Pollutants in the Chemical Industry

\begin{tabular}{|l|c|c|c|c|c|c|}
\hline Fuel Types & $\begin{array}{l}\text { Carbon Coefficient, } \\
\text { lbs CO2/million BTU }\end{array}$ & \multicolumn{7}{l|}{$\begin{array}{l}\text { Other Combustion Products, lbs/million } \\
\text { BTU }\end{array}$} \\
& & \multicolumn{7}{l}{} \\
& & SOx & NOx & CO & Particulates & VOCs \\
\hline & 161.2 & 0.16 & 0.14 & 0.036 & 0.01 & 0 \\
\hline Distillate Fuel & 116.9 & 0 & 0.14 & 0.035 & 0.003 & 0.006 \\
\hline Natural Gas & 207.5 & 2.5 & 0.95 & 0.304 & 0.003 & 0.006 \\
\hline Coal & 133.4 & 1.45 & 0.55 & 0.176 & 0.4 & 0.004 \\
\hline $\begin{array}{l}\text { Purchased } \\
\text { Electricity }\end{array}$ & 163.3 & 1.7 & 0.37 & 0.033 & 0.08 & 0.009 \\
\hline Unfinished Oil & & &
\end{tabular}


Table 6: Energy Usage Distribution in the Distillation Processes

\begin{tabular}{|c|c|c|c|c|c|}
\hline \multirow[b]{2}{*}{ Processes } & \multicolumn{5}{|c|}{ Percentage of Fuel Type Contributions } \\
\hline & $\begin{array}{l}\text { Distillate } \\
\text { Fuel and } \\
\text { Petroleum } \\
\text { Gas }\end{array}$ & $\begin{array}{l}\text { Natural } \\
\text { Gas }\end{array}$ & $\begin{array}{l}\text { Coal or } \\
\text { Petroleum } \\
\text { Coke } \\
\end{array}$ & $\begin{array}{l}\text { Purchased } \\
\text { Electricity }\end{array}$ & $\begin{array}{l}\text { Unfinished } \\
\text { Oil }\end{array}$ \\
\hline Hydrogen peroxide & $0 \%$ & $100 \%$ & $0 \%$ & $0 \%$ & $0 \%$ \\
\hline Aromatics & $12 \%$ & $72 \%$ & $10 \%$ & $6 \%$ & $0 \%$ \\
\hline Olefins & $11 \%$ & $63 \%$ & $8 \%$ & $18 \%$ & $0 \%$ \\
\hline Oxygenated hydrocarbons & $11 \%$ & $63 \%$ & $8 \%$ & $18 \%$ & $0 \%$ \\
\hline Refining - C3/C4 fractionation & $12 \%$ & $72 \%$ & $10 \%$ & $6 \%$ & $0 \%$ \\
\hline
\end{tabular}

Table 7: Reduction in Environmental Pollutants in the Distillation Processes

\begin{tabular}{|c|c|c|c|c|c|c|}
\hline & \multicolumn{2}{|c|}{ Equivalent $\mathrm{I}$} & \multicolumn{4}{|c|}{ Reduction in Environmental Pollutants , Million lbs } \\
\hline Processes & $\mathrm{CO} 2$ & $\mathrm{SOx}$ & NOx & $\mathrm{CO}$ & Particulates & VOCs \\
\hline Hydrogen peroxide & 81.83 & 0 & 0.098 & 0.025 & 0.002 & 0.004 \\
\hline Aromatics & 251.305 & 0.677 & 0.467 & 0.134 & 0.053 & 0.01 \\
\hline Olefins & 435.57 & 1.579 & 0.919 & 0.271 & 0.248 & 0.016 \\
\hline Oxygenated hydrocarbons & 1913.87 & 6.94 & 4.04 & 1.189 & 1.091 & 0.072 \\
\hline $\begin{array}{c}\text { Refining - C3/C4 } \\
\text { fractionation }\end{array}$ & 824.017 & 2.219 & 1.53 & 0.439 & 0.172 & 0.032 \\
\hline TOTAL & 3506.59 & 11.41 & 7.05 & 2.06 & 1.57 & 0.13 \\
\hline
\end{tabular}

Similar calculations were carried out for MEE as shown in Tables 8, and 9 with major environmental emission reduction equivalent of 3.9 billion lbs of $\mathrm{CO} 2$ per year.

Table 8: Energy Usage Distribution in the MEE Processes

\begin{tabular}{|l|r|r|r|r|r|}
\hline & \multicolumn{3}{|c|}{ Percentage } & \multicolumn{2}{l|}{ of Fuel Type Contributions } \\
\hline & $\begin{array}{l}\text { Distillate } \\
\text { Fuel and } \\
\text { Petroleum } \\
\text { Gas }\end{array}$ & $\begin{array}{l}\text { Natural } \\
\text { Gas }\end{array}$ & $\begin{array}{l}\text { Coal or } \\
\text { Petroleum } \\
\text { Coke }\end{array}$ & $\begin{array}{l}\text { Purchased } \\
\text { Electricity }\end{array}$ & $\begin{array}{l}\text { Unfinished } \\
\text { Oil }\end{array}$ \\
\hline Soda Ash & $0 \%$ & $30 \%$ & $65 \%$ & $5 \%$ & $0 \%$ \\
\hline Caustic Soda & $0 \%$ & $\mathbf{8 6 \%}$ & $\mathbf{1 1 \%}$ & $\mathbf{3 \%}$ & $0 \%$ \\
\hline Black-liquor concentrator & $0 \%$ & $30 \%$ & $65 \%$ & $5 \%$ & $0 \%$ \\
\hline Ethanol-DDGS & $0 \%$ & $30 \%$ & $65 \%$ & $5 \%$ & $0 \%$ \\
\hline
\end{tabular}


Table 9: Reduction in Environmental Pollutants in the MEE Processes

\begin{tabular}{|l|r|r|r|r|r|r|}
\hline & \multicolumn{5}{|c|}{ Equivalent } & \multicolumn{3}{l|}{ Reduction in Environmental Pollutants , Million } \\
\hline Processes & \multicolumn{1}{|c|}{ CO2 } & \multicolumn{1}{|c|}{ SOx } & NOx & CO & \multicolumn{1}{l|}{$\begin{array}{l}\text { Particulat } \\
\text { es }\end{array}$} & VOCs \\
\hline Soda Ash & 264.92 & 2.55 & 1.03 & 0.33 & 0.03 & 0.01 \\
\hline Caustic Soda & 509.44 & 1.27 & 0.97 & 0.28 & 0.06 & 0.02 \\
\hline $\begin{array}{l}\text { Black-liquor } \\
\text { concentrator }\end{array}$ & 1677.84 & 16.13 & 6.53 & 2.06 & 0.22 & 0.06 \\
\hline Ethanol-DDGS & 1395.26 & 13.41 & 5.43 & 1.71 & 0.18 & 0.05 \\
\hline TOTAL & 3847.47 & 33.36 & 13.95 & 4.37 & 0.49 & 0.14 \\
\hline
\end{tabular}

The indirect environmental benefits for this project include savings on industrial plants cooling water. Many industrial plants are facing a scarcity of cooling capacity. In water-scarcity regions, the problem is even more severe for supply of make-up water for cooling towers and feed-water to the boiler. Successful implementation of this technology would help alleviate the water problem by recovering and recycling the heat. Also, the absorption cycle can reject heat to evaporative coolers/condensers or even to air, because ammonia is a good heat-transfer medium for rejecting heat.

Industry-wide application of thermal heat pumps will alleviate the water problem by recovering and recycling the latent heat that would otherwise lost to the ambient. The energy recovered by this technology would have been rejected in cooling towers with corresponding utilization of makeup water from natural water supplies. Therefore, from a DOE source, equivalent water savings estimated from the energy savings are as shown in Tables 10 and 11 with a total equivalent water savings of about 6 billion gallons of fresh water per year for the distillation and MEE processes. The actual savings of water is higher than estimated due to continuous purge required to maintain chemical and salt concentrations of the cooling tower water. By reducing the demand for cooling tower waters, this technology will significantly reduce use and discharge of water treatment chemicals. Energy consumption associated with water supply and treatments can vary between $1,900 \mathrm{kWh}$ and 23,700 $\mathrm{kWh}$ per million-gallon water depending on sources of natural waters [US DOE, 2006].

Table 10: Equivalent Water Savings in Distillation Processes

\begin{tabular}{|l|r|r|}
\hline & $\begin{array}{l}\text { Energy } \\
\text { Savings in } \\
\text { 2020, } \\
\text { trillion } \\
\text { Btu }\end{array}$ & $\begin{array}{l}\text { Equivalent Water } \\
\text { Savings, Million } \\
\text { gallons }\end{array}$ \\
\hline Hydrocesses & 0.7 & 84.1 \\
\hline Aromatics & 1.9 & 228.2 \\
\hline Olefins & 3.3 & 396.3 \\
\hline Oxygenated hydrocarbons & 14.5 & 1741.2 \\
\hline Refining - C3/C4 fractionation & 6.23 & 748.1 \\
\hline TOTAL & 26.63 & 3197.9 \\
\hline
\end{tabular}


Table 11: Equivalent Water Savings in MEE Processes

\begin{tabular}{|l|r|l|}
\hline & $\begin{array}{l}\text { Energy } \\
\text { Savings in } \\
\text { 2020, } \\
\text { trillion } \\
\text { Btu }\end{array}$ & $\begin{array}{l}\text { Equivalent Water } \\
\text { Savings, Million } \\
\text { gallons }\end{array}$ \\
\hline Soda Ash & 1.5 & 180.1 \\
\hline Caustic Soda & 4 & 480.3 \\
\hline Black-liquor concentrator & 9.5 & 1140.8 \\
\hline Ethanol-DDGS & 7.9 & 948.7 \\
\hline TOTAL & 22.9 & 2750.0 \\
\hline
\end{tabular}

\subsubsection{Market Benefits}

Distillation, MEE and crystallization are widely used in petroleum, chemical, food processing, and pulp \& paper industries. In addition, increased production of fuel-grade ethanol requires energy efficiency distillation and MEE for favorable net-energy balance of ethanol. All these processes will benefit from waste-heat powered thermal heat pump and thermally active trays and packed columns.

\section{Distillation Processes}

This integrated absorption heat-pump distillation can be readily applied in near term to the following distillation processes with close-boiling separations and high specific energy consumption (shows normal boiling point range).

$>$ de-propanizer and de-butanizer columns in refining $\left(-42^{\circ} \mathrm{C}\right.$ to $\left.-0.6^{\circ} \mathrm{C}\right)$

$>$ benzene-toluene-xylene (BTX) $\left(80^{\circ} \mathrm{C}\right.$ to $\left.138-144^{\circ} \mathrm{C}\right)$

$>$ ethylbenzene-styrene $\left(136^{\circ} \mathrm{C}\right.$ to $\left.145^{\circ} \mathrm{C}\right)$

$>$ isopropanol-water $\left(82^{\circ} \mathrm{C}\right.$ to $\left.100^{\circ} \mathrm{C}\right)$

In long term the proposed technology would be applicable to reactive distillations: a) esterification; b) liquid-phase desulfurization; c) isomerization; e) dehydration of alcohols; f) hydration; g) aromatic alkylation; and nitration.

\section{MEE and Crystallization Processes}

Evaporation and crystallization are key separation processes for concentrating and purifying both inorganic and organic solid products. Process industry applications include salt production, purification and separation of organics, black liquor concentration in the pulping process, recovery of distillers' dried grains with solubles (DDGS) in corn mills, sugar production, fruit juice concentration, soda ash manufacturing, and various environmental treatments. The applications in these sectors cover a wide range of process functions, such as concentration, purification, solidification, and the production of crystalline products. 


\section{Task 2: Identification and Characterization of Working Fluid Pair for Moderate- Temperature Heat Pumps}

\subsection{Task Objective}

The purpose of this task was to identify and characterize working fluid pairs for recovering latent heat for temperatures $\left(50^{\circ} \mathrm{C}\right.$ to $\left.100^{\circ} \mathrm{C}\right)$ typical of industrial processes. The task involved compiling a list of working fluids and evaluating their thermo-physical properties for high-temperature applications. The objective was to down-select working fluid pairs based on merit criteria for applications in multi-effect evaporation and distillation processes with the focus on FMC's soda ash and $\mathrm{H} 2 \mathrm{O} 2$ production units.

\subsection{Property Requirements}

The basic property requirements with the focus on soda ash triple effect evaporation and hydrogen peroxide distillation are summarized in Table 1. Although, mechanical vapor recompression (MVR) is not included in this project scope of work, it is shown for a comparative analysis only. The three fundamental temperatures used to characterize working fluid pairs are: a) low-end temperature from where latent heat is recovered; b) high-end temperature where heat is to be delivered; and 3) temperature at which heat of absorption can be rejected by preheating the process fluid. In the soda ash processes, the latent heat from the barometric condenser is recovered at about $65^{\circ} \mathrm{C}$. The thermal heat pump augments its thermodynamic state with a temperature lift in the range of $50^{\circ} \mathrm{C}$ to $70^{\circ} \mathrm{C}$ to utilize the latent heat at the $1^{\text {st }}$ effect. Similarly, the latent heat from the overhead condenser is recovered at about $60^{\circ} \mathrm{C}$ and augmented to be supplied to the reboiler with temperature lift in the range of $20^{\circ} \mathrm{C}$ to $30^{\circ} \mathrm{C}$. In both cases, the heat of absorption is used to preheat the feed stream. The vapor/liquid equilibrium pressures at these temperatures would be one of the major criteria for selecting working fluid pairs; too high pressure or deep vacuum are not preferred. Heat of mixing is the other important criterion followed by corrosion, toxicity, and solubility to minimize scale formation on heat exchangers, chemical stability and costs. Other criteria as listed in Tables 1 are qualitatively evaluated and numerical merit values are given for ranking the working fluid pairs. 
Table 1. Property requirements of working fluid

pairs

\begin{tabular}{|c|c|c|c|}
\hline & \multirow[t]{2}{*}{1} & Soda Ash Process & \multirow{2}{*}{$\begin{array}{c}\mathrm{H}_{2} \mathbf{O}_{2} \text { Process } \\
\text { Distillation }\end{array}$} \\
\hline & & Tripple Effect & \\
\hline $\begin{array}{c}1 \\
-\frac{-}{2}-\end{array}$ & 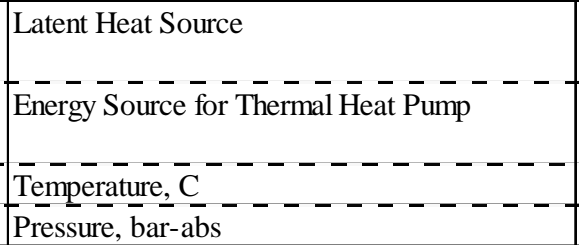 & \begin{tabular}{c:c} 
Heat Rejection from & Low Pressure Steam \\
\hdashline 3rd Effect & Steam plus Thermal \\
\hdashline Primary Steam plus & Calciner Exhaust \\
\hdashline-65 & Calciner Exhaust \\
\hdashline Vacuum &
\end{tabular} & 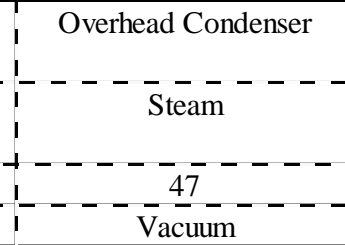 \\
\hline $\begin{array}{l}-8 \\
-\frac{8}{10} \\
-1 \frac{1}{1}\end{array}$ & 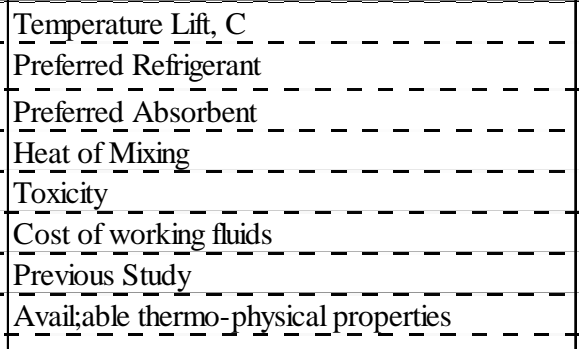 & 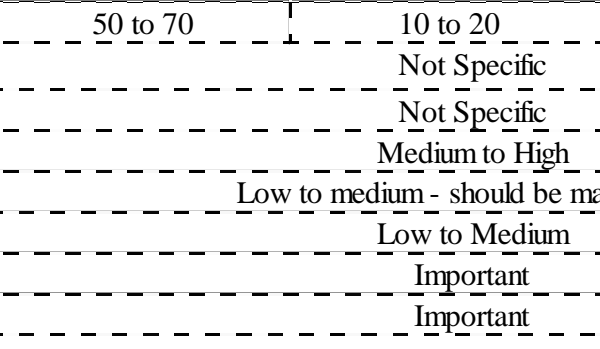 & _ _ 20 to 30 . . \\
\hline
\end{tabular}

\subsection{Working Fluid Pairs}

The Project Team developed a list of potential working fluid pairs as presented in Table 2. The database of potential working fluids prepared by Macriss and Zawacki [1989] provided an initial assessment of working fluid pairs for this project. Ammonia-water and lithium bromide-water are working fluid pairs predominantly used for thermally-activated refrigeration and air-conditioning applications. These two working fluid pairs can be considered for thermal heat pump applications; however, they cannot be used for higher temperatures. Ammonia-water and lithium bromide-water are kept in the list as reference fluids for potential low-temperature applications. Erickson and Howe [1989] proposed using aqueous solution of alkaline nitrate salts, namely lithium nitrate $\left(\mathrm{LiNO}_{3}\right)$, potassium nitrate $\left(\mathrm{KNO}_{3}\right)$, and sodium nitrate $\left(\mathrm{NaNO}_{3}\right)$ for high-temperature applications in a composition shown in Table 2. Zhuo and Machielsen [1995] showed that alkaline nitrate-water working fluid pair can be used for temperatures up to $260^{\circ} \mathrm{C}$ with high temperature lifts. Recently, Avarez et al. [2011] and Vargas [2008] analyzed this alkaline nitrate-water working fluid pair and proposed an alternate sodium salt, sodium nitrite $\left(\mathrm{NaNO}_{2}\right)$, to extend solubility and minimize potential for crystallization of salts. Sodium nitrate is replaced with sodium nitrite $\left(\mathrm{NaNO}_{2}\right)$ in composition shown in Table 2A and Table 2B.

A second class of emerging working fluid pairs includes ionic fluids as shown in Table 2A, [Kim et al., 2010; Bosemann and Schubert, 2008]. Ionic fluids can be customized for maximizing the overall efficiency of thermal heat pumps. The heat transfer fluid, such as 2-2-2 trifluoroethanol (TFE), is easily absorbed in ionic fluids, such as 1-butyl-3-methyl imidazolium tetrafluoroborate ([BMlm][BF4]). Furthermore, the thermal fluid can be easily separated from the ionic fluid upon heating because ionic fluids have very low vapor pressures. Ionic working fluid pairs listed in Table 2A have potential applications for high-temperature thermal heat pumps; however, further developments, specifically reliable thermo-physical properties, are required before they can be considered for industrial applications. ORNL's report [1989] presented a list of working fluid pairs for heat pump applications. However, most of them were low-temperature applications. The three potential candidates organic working fluid pairs applicable to industrial heat pumps were selected for further evaluation, as shown in Table 2A. Bokelmann et al. [1986] evaluated these organic fluid pairs for heat pump applications. 
Table 2A. Candidate working fluid pairs for industrial thermal heat pumps

\begin{tabular}{|c|c|c|c|c|c|}
\hline \begin{tabular}{r|r} 
& \\
1 & Priority \\
1 & \\
1 & \\
1 & \\
\hdashline & 1
\end{tabular} & i & Refrigerant & Absor & $\mid \begin{array}{c}\text { Property Sources } \\
----\ldots---\end{array}$ & 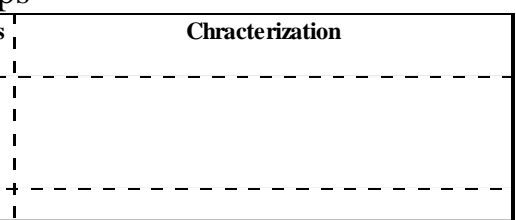 \\
\hline 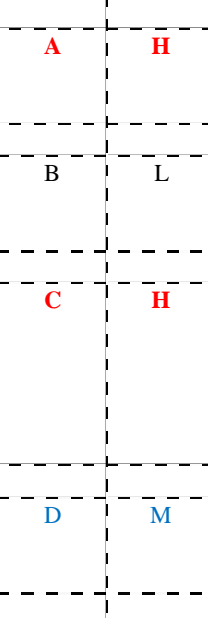 & $\begin{array}{l}\text { Lithium Bromide/ } \\
\text { Water } \\
\text { Alkiline Nitrates } \\
y_{1}\end{array}$ & $\left\{\begin{array}{l}\text { Ammonia } \\
----- \\
\text { Water }\end{array}\right.$ & 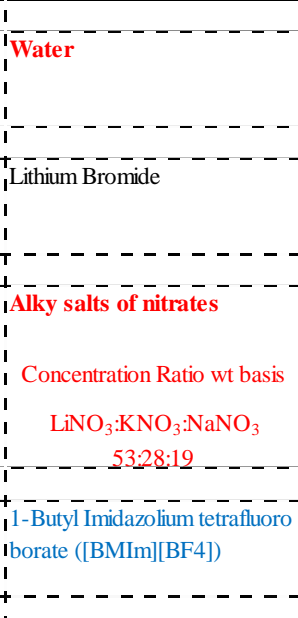 & 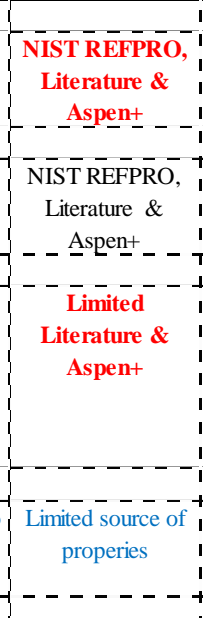 & $\begin{array}{l}\text { vorking fluid pair for low temperatures. } \\
\text { ited for triple effect.; likely suited for } \\
\text { distillation. } \\
\text { usation and corrosion issues. } \\
\text { ineally for higher tenperature and } \\
\text { rature lift. }\end{array}$ \\
\hline \begin{tabular}{c:c}
$\mathrm{E}$ & $\mathrm{M}$ \\
\hdashline $\mathrm{F}$ & $\mathrm{M}$ \\
\hdashline $\mathrm{G}$ & $\mathrm{M}$ \\
\hdashline
\end{tabular} & Ionic Fluid B & R134a & 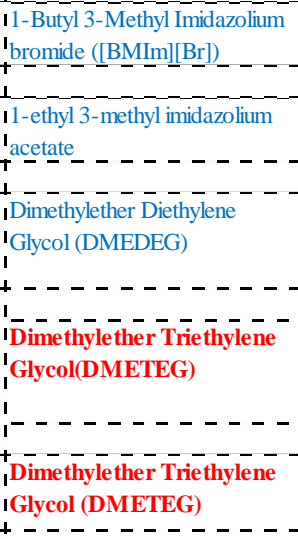 & 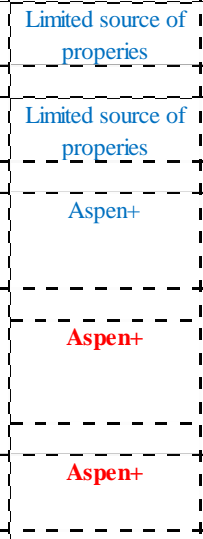 & $\begin{array}{l}\text { roperties. }-1- \\
\text { advantageous } \\
\text { properties. }\end{array}$ \\
\hline
\end{tabular}


Table 2B: Identification of Working Fluids with typical operating temperatures

\begin{tabular}{|c|c|c|c|c|c|c|}
\hline & \multirow{2}{*}{ Name } & \multirow{2}{*}{ Refrigerant } & \multirow{2}{*}{ Absorbents } & \multicolumn{2}{|c|}{$\begin{array}{l}\text { Typical Operating } \\
\text { Temperatures }\end{array}$} & \multirow{2}{*}{$\begin{array}{c}\begin{array}{c}\text { Temp Lift } \\
\text { - Single } \\
\text { stage }\end{array} \\
\text { C }\end{array}$} \\
\hline & & & & High $\mathrm{C}$ & Low C & \\
\hline & & & & & & \\
\hline $\mathrm{A}$ & NH3-H2O & Ammonia & Water & 120 & -28 & 30 to 50 \\
\hline $\mathrm{B}$ & $\mathrm{LiBr} / \mathrm{H} 2 \mathrm{O}$ & Water & Lithium Bromide & 100 & 6 & 20 to 30 \\
\hline $\mathrm{C}$ & Alkytrate & Water & Alky salts of nitrates & 200 & 100 & $>50$ \\
\hline & & & 20 mole \% $\mathrm{LiNO}_{3}$ & & & \\
\hline & & & 20 mole $\% \mathrm{KNO}_{3}$ & & & \\
\hline & & & 10 mole $\% \mathrm{NaNO}_{3}$ & & & \\
\hline $\mathrm{D}$ & Ionic Fluid A & $\begin{array}{l}\text { Trifluoro } \\
\text { ethanol } \\
\text { (TFE) }\end{array}$ & $\begin{array}{l}\text { 1-Butyl Imidazolium } \\
\text { tetrafluoro borate } \\
([\mathrm{BMIm}][\mathrm{BF} 4])\end{array}$ & TBD & TBD & TBD \\
\hline$E$ & Ionic Fluid B & $\begin{array}{l}\text { Trifluuoro } \\
\text { ethanol } \\
\text { (TFE) }\end{array}$ & $\begin{array}{c}\text { 1-Butyl 3-Methyl } \\
\text { Imidazolium bromide } \\
\text { ([BMIm][Br]) }\end{array}$ & TBD & TBD & TBD \\
\hline $\mathrm{F}$ & Ionic Fluid C & Methanol & $\begin{array}{c}\text { 1-ethyl 3-methyl } \\
\text { imidazolium acetate }\end{array}$ & TBD & TBD & TBD \\
\hline & & & & & & \\
\hline$G$ & Organic A & R134a & $\begin{array}{c}\text { Dimethylether } \\
\text { Diethylene Glycol }\end{array}$ & TBD & TBD & TBD \\
\hline $\mathrm{H}$ & Organic B & R134a & $\begin{array}{c}\text { Dimethylether } \\
\text { Triethylene Glycol }\end{array}$ & TBD & TBD & TBD \\
\hline
\end{tabular}




\subsection{Property Database}

Aspen+ was used for the systems analysis. Consequently, thermo-physical properties of the candidate working fluids were calculated using Aspen+ program and compared with available properties. However, Aspen+ database does not include ionic fluids listed in Table 2A. Properties of ammonia-water and lithium bromide-water working fluids were compared with predictions by the NIST program REFPRO. This program is developed by NIST specifically for refrigerants and working fluid pairs for common absorption chilling applications and it does not properties for organic fluids as well as ionic fluids.

The major thermo-physical properties calculated and tabulated are: vapor pressure; density; enthalpy; specific heat; viscosity, thermal conductivity and surface tension. The heat of mixing can be estimated from vapor phase enthalpy and enthalpies of pure components in the liquid phase. For example, vapor phase (mostly water vapor in equilibrium with nitrate solution) enthalpy of alkaline nitrates at $100^{\circ} \mathrm{C}$ and $50 \%$ liquid concentration is 5,715 Btu/lb, while the liquid phase enthalpy is 4,083 Btu/lb. This represents enthalpy change of 1,628 Btu/lb, which is significantly greater than the latent heat of condensation of water of $970 \mathrm{Btu} / \mathrm{lb}$ at $100^{\circ} \mathrm{C}$. In general, working fluid pairs with high heat of mixing would yield better overall efficiency. The thermo-physical properties calculated by Aspen+ for candidate working fluid pairs were found to be reasonably accurate for the systems analysis.

\subsection{Screening Analysis}

The screening analysis is based on twelve merit criteria as presented in Table 3. A critical analysis of the literature and availability of thermo-physical properties provided general guidelines for down-selecting working fluid pairs. The two working fluid pairs selected are: a) alkaline nitrate-water; and b) organic-C, TFE-DMETEG, with a possibility of ammonia-water for hydrogen-peroxide distillation. A summary of justification is as follows:

$>$ Ionic fluids are emerging working fluids for high-efficiency thermal heat pumps; however, lack of property data and/or reliable prediction methods limits their near-term applications.

$>$ Corrosion and possibility of crystallization limit use of lithium bromide-water for high-temperature thermal heat pumps.

$>$ Ammonia-water working fluid pair has good thermo-physical properties; however, it cannot be used for high temperature applications due to relatively high pressure of ammonia at temperatures typical of multi-effect evaporation and distillation processes. Also, toxicity of ammonia may be an issue for some industrial plants.

$>$ Alkaline-nitrates working fluid pair is a leading candidate with good thermo-physical properties and potentials for high overall efficiency. A variant of this working fluid pair replacing sodium nitrate with sodium nitrite is also a good candidate.

$>$ Among organic working fluid pairs with DMETEG as absorbent, trifluoroethanol (TFE) has better thermo-physical properties than R134a. 
Table 3. Merit criteria of working fluids

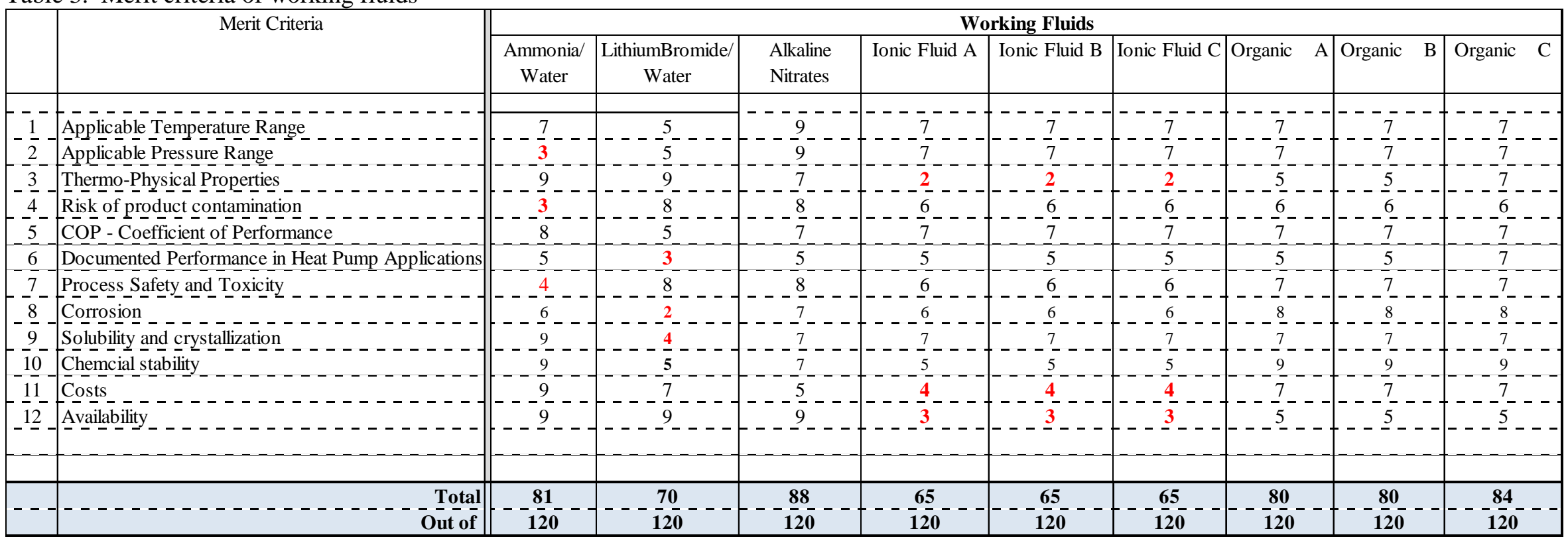

Notes

1 Corrosion and crystallization issues limits use of $\mathrm{LiBr} / \mathrm{H} 2 \mathrm{O}$ for high-temperature heat pump applications

2 Ionic fluid should have good thermo-physical properties; howevr, lack of data and relaible prediciotn methods would limit their use in near future.

3 Ammonia-water mixture has good thermo-physical properties but have temperature and pressure limits; may be considered for $\mathrm{H} 2 \mathrm{O} 2$ distillation but not suited for thriple effect.

4 Selected Fluids:

Alkaline Nitrates: LiNO3:KNO3:NaNO3 Nitrates in wt ratio 53:28:19

Alternate Alkaline Nitrates: LiNO3:KNO3:NaNO2 Nitrates in wt ratio 53:35:12

Organic C: Trifluorethanol (TFE)/Dimethylether Triethylene Glycol (DMETEG)

Ammonia/Water: For $\mathrm{H} 2 \mathrm{O} 2$ distillation or other lower temperature applications. 


\section{Task 3 Systems Analysis of Distillation and MEE Processes}

The purpose of this task is to select candidate distillation and MEE/crystallization processes for detailed technoeconomic analysis. With input from FMC plants, five separation processes, including distillation and $\mathrm{MEE} / \mathrm{crystallization} \mathrm{were} \mathrm{screened} \mathrm{to} \mathrm{down-select} \mathrm{to} \mathrm{two} \mathrm{processes.} \mathrm{Analysis} \mathrm{using} \mathrm{chemical} \mathrm{process}$ simulation software was performed to determine optimal conditions for heat recovery and recycling back into these processes without adversely affecting the process unit and potential energy savings. Subsequently, process streams from which heat is recovered and recycled were evaluated for potential fouling and corrosion of heat exchangers. Direct coupling of the waste heat and front-end of the process for heat recycling was analyzed and heat-exchangers design were evaluated.

\subsubsection{Task 3A: System Analysis of MEE Processes}

The system analysis for the MEE processes was carried out based on the two promising heat pump fluids identified in Task 2 of the project : LiNO3+KNO3+NaNO3 (53:28:19 mass ratio) and LiNO3+ KNO3+NaNO3 (53:35:12 mass ratio).

\subsubsection{A.1 MEE Benchmark}

Table 3A:1a summarized the current performance of the MEE process for 105,122lb/hr primary steam import and 152,012lb/hr mono production. As shown, the exchanger duties are 99.2MMbtu/hr for the first effect (HE2501), 86.5MMBtu/hr for the second effect (HE-2502) and 83.2MMBtu/hr for the third effect (HE-2503). The steam generations are $88,433 \mathrm{lb} / \mathrm{hr}, 81,522 \mathrm{lb} / \mathrm{hr}$ and $84,843 \mathrm{lb} / \mathrm{hr}$, respectively, for the effects. The fresh feed to the process at $60^{\circ} \mathrm{C}$ is estimated to be $439,461 / \mathrm{hr}(69.17 \mathrm{wt} \% \mathrm{H} 2 \mathrm{O}, 30.51 \mathrm{wt} \% \mathrm{Na} 2 \mathrm{CO}, 0.25 \mathrm{wt} \% \mathrm{NaCL}$ and $0.08 \mathrm{wt} \% \mathrm{Na} 2 \mathrm{SO} 4)$ the indicated production rate.

Table $1 \mathrm{~b}$ summarized the sensitivity of the process for increased steam to the primary exchanger at $119,882 \mathrm{lb} / \mathrm{hr}$. The production for this case becomes 173,210lb/hr mono, with the exchanger duties 113.2MMbtu/hr for the first effect (HE-2501), 99.3MMBtu/hr for the second effect (HE-2502) and 95.4MMBtu/hr for the third effect (HE-2503). The steam generations for the effects are 101,528lb/hr, $93,417 \mathrm{lb} / \mathrm{hr}$ and $95,886 \mathrm{lb} / \mathrm{hr}$, respectively, with the fresh feed to the process estimated at 496,693 lb/hr.

\subsubsection{A.2 MEE Performance for Heat Pump (LiNO3+KNO3+NaNO3 53:28:19)}

Table 3A:2 summarized the performance of the MEE process for this heat pump. As shown, the primary steam import for the process is $78,137 \mathrm{lb} / \mathrm{hr}$, while the heat exchanger duties are $67.3 \mathrm{MMbtu} / \mathrm{hr}$ for the first effect (HE2501), 73.3MMBtu/hr for the second effect (HE-2502) and 96.8MMBtu/hr for the third effect. The steam generations are 74,848lb/hr; 95,489lb/hr and 121,166lb/hr respectively, for the effects. A portion of the savings in duty for the first effect exchanger over the MEE benchmark is due to the preheating of the MEE feed $(498,276 \mathrm{lb} / \mathrm{hr})$ from $60^{\circ} \mathrm{C}$ to $104.7^{\circ} \mathrm{C}$ by the heat pump, before direct feed to the crystallizers. The estimated capacity of the process is $174,066 \mathrm{lb} / \mathrm{hr}$ soda ash (Na2CO3.H2O), essentially the same as the benchmark in the sensitivity study in Table 3A:1b.

For this study, the heat pump fluid was held at 449,531lb/hr with $41 \mathrm{wt} \%$ salt. Also, the solubility data in the literature for the fluid was used in the analysis. Consistent with this data, no salt precipitation was predicted for the temperature range of operation of the heat pump.

\subsubsection{A.3 MEE Performance for Heat Pump (LiNO3+KNO3+NaNO2 53:35:12)}

Table 3A:3 summarized the performance of the MEE process for this heat pump. As shown, the primary steam import for the process is 75,697lb/hr, while the exchanger duties are 67.3MMbtu/hr for the first effect (HE2501), 72.8MMBtu/hr for the second effect (HE-2502) and 95.5MMBtu/hr for the third effect. The steam generations are 74,441lb/hr; 94,263lb/hr and 119,022lb/hr, respectively, for the effects. As before, the MEE feed $(492,485 \mathrm{lb} / \mathrm{hr})$ is preheated from $60^{\circ} \mathrm{C}$ to $104.7^{\circ} \mathrm{C}$ by the heat pump and fed directly to the crystallizers, resulting in a portion of the savings of heat duty savings for the first effect exchanger over the MEE benchmark (Table 3A:1b). The capacity of the process is 172,375lb/hr soda ash (Na2CO3.H2O), almost the same as the benchmark in Table 3A:1b. 
The heat pump fluid used for this case was $452,955 \mathrm{lb} / \mathrm{hr}$ with $41 \mathrm{wt} \%$ salt concentration. The solubility data in the literature for this heat pump fluid was used in the analysis. Consistent with this data, no salt precipitation was predicted for the temperature range of operation of the heat pump. 
Table 3A:1a. MEE Benchmark

\begin{tabular}{|c|c|c|c|c|c|c|c|c|c|c|}
\hline $\begin{array}{l}\text { Effect } \\
\text { Exchanger }\end{array}$ & \begin{tabular}{|c|}
$\mathrm{U}$ \\
Btu/ft' \\
\end{tabular} & $\begin{array}{c}\text { Area } \\
\mathrm{ft}^{2}\end{array}$ & $\begin{array}{c}\text { UA } \\
\text { Btu/hr.R }\end{array}$ & \begin{tabular}{|c}
$\begin{array}{c}\text { Area Calc } \\
\mathrm{ft}^{2}\end{array}$ \\
\end{tabular} & \begin{tabular}{|c|} 
Proc Tin \\
${ }^{\circ} \mathrm{C}$
\end{tabular} & \begin{tabular}{|c|}
$\begin{array}{c}\text { Proc Tout } \\
{ }^{\circ} \mathrm{C}\end{array}$ \\
\end{tabular} & $\begin{array}{c}\text { Steam Tin } \\
{ }^{\circ} \mathrm{C}\end{array}$ & $\begin{array}{c}\text { Steam Tout } \\
{ }^{\circ} \mathrm{C}\end{array}$ & $\begin{array}{c}\text { Duty } \\
\text { MMBtu/hr }\end{array}$ & $\begin{array}{c}\text { Steam Gen } \\
\mathrm{lb} / \mathrm{hr}\end{array}$ \\
\hline HE-2501 & 374 & 15,300 & $2,344,340$ & 6,268 & 102.9 & 106.7 & 128.4 & 128.4 & 99.2 & 88,433 \\
\hline HE-2502 & 374 & 15,300 & $5,790,427$ & 15,482 & 86.9 & 88.6 & 96.1 & 96.1 & 86.5 & 81,522 \\
\hline HE-2503 & 374 & 15,300 & $2,789,568$ & 7,459 & 63.6 & 66.8 & 81.9 & 81.9 & 83.2 & 84,843 \\
\hline \multicolumn{11}{|c|}{ 1. Primary Steam Import 105,122 lb/hr } \\
\hline \multicolumn{11}{|c|}{ 2. Fresh Feed for MEE } \\
\hline \multicolumn{11}{|c|}{ 3. Production Mono } \\
\hline
\end{tabular}

Table 3A:1b. MEE Benchmark Sensitivity to Higher Primary Steam Rate

\begin{tabular}{|c|c|c|c|c|c|c|c|c|c|c|}
\hline $\begin{array}{l}\text { Effect } \\
\text { Exchanger }\end{array}$ & $\begin{array}{c}\mathrm{U} \\
\text { Btu/ft².hr.R }\end{array}$ & $\begin{array}{c}\text { Area } \\
\mathrm{ft}^{2}\end{array}$ & $\begin{array}{c}\text { UA } \\
\text { Btu/hr.R }\end{array}$ & $\begin{array}{c}\text { Area Calc } \\
\mathrm{ft}^{2}\end{array}$ & $\begin{array}{c}\begin{array}{c}\text { Proc Tin } \\
{ }^{\circ} \mathrm{C}\end{array} \\
\end{array}$ & \begin{tabular}{|c|}
$\begin{array}{c}\text { Proc Tout } \\
{ }^{\circ} \mathrm{C}\end{array}$ \\
\end{tabular} & $\begin{array}{c}\text { Steam Tin } \\
{ }^{\circ} \mathrm{C}\end{array}$ & $\begin{array}{c}\text { Steam Tout } \\
{ }^{\circ} \mathrm{C}\end{array}$ & $\begin{array}{c}\text { Duty } \\
\text { MMBtu/hr }\end{array}$ & $\begin{array}{c}\text { Steam Gen } \\
\mathrm{lb} / \mathrm{hr}\end{array}$ \\
\hline HE-2501 & 374 & 15,300 & $2,702,236$ & 7,225 & 102.9 & 107.2 & 128.4 & 128.4 & 113.2 & 101,528 \\
\hline HE-2502 & 374 & 15,300 & $6,746,076$ & 18,038 & 86.9 & 88.8 & 96.1 & 96.1 & 99.3 & 93,417 \\
\hline HE-2503 & 374 & 15,300 & $3,299,741$ & 8,823 & 63.7 & 67.7 & 81.9 & 81.9 & 95.4 & 95,886 \\
\hline \multicolumn{11}{|c|}{ 1. Primary Steam Import $\sim 119,882 \mathrm{lb} / \mathrm{hr}$} \\
\hline \multicolumn{11}{|c|}{ 2. Fresh Feed for MEE $\sim 496,693 \mathrm{lb} / \mathrm{hr}\left(60^{\circ} \mathrm{C}\right)$} \\
\hline \multicolumn{11}{|c|}{ 3. Production Mono } \\
\hline
\end{tabular}

Table 3A:2. MEE Performance for Heat Pump (LiNO3:KNO3:NaNO3 53:28:19)

\begin{tabular}{|c|c|c|c|c|c|c|c|c|c|c|}
\hline \begin{tabular}{|l} 
Effect \\
Exchanger
\end{tabular} & \begin{tabular}{|c|}
$\mathrm{U}$ \\
Btu/ft ${ }^{2} \cdot h r . R$ \\
\end{tabular} & $\begin{array}{c}\text { Area } \\
\mathrm{ft}^{2}\end{array}$ & $\begin{array}{c}\text { UA } \\
\text { Btu/hr.R }\end{array}$ & $\begin{array}{c}\text { Area Calc } \\
\mathrm{ft}^{2}\end{array}$ & $\begin{array}{c}\text { Proc Tin } \\
{ }^{\circ} \mathrm{C}\end{array}$ & $\begin{array}{c}\text { Proc Tout } \\
{ }^{\circ} \mathrm{C}\end{array}$ & $\begin{array}{c}\text { Steam Tin } \\
{ }^{\circ} \mathrm{C}\end{array}$ & $\begin{array}{c}\text { Steam Tout } \\
{ }^{\circ} \mathrm{C}\end{array}$ & $\begin{array}{c}\text { Duty } \\
\text { MMBtu/hr }\end{array}$ & $\begin{array}{c}\text { Steam Gen } \\
\text { lb/hr }\end{array}$ \\
\hline HE-2501 & 374 & 15,300 & $3,560,629$ & 9,520 & 103.2 & 105.7 & 123.2 & 108.9 & 67.3 & 74,848 \\
\hline HE-2502 & 374 & 15,300 & $4,886,707$ & 13,066 & 87.0 & 88.5 & 96.1 & 96.1 & 73.3 & 95,489 \\
\hline HE-2503 & 374 & 15,300 & $3,197,683$ & 8,550 & 63.8 & 66.2 & 81.9 & 81.9 & 96.8 & 121,166 \\
\hline \multicolumn{11}{|c|}{ 1. Primary Steam Import $~ 78,137 \mathrm{lb} / \mathrm{hr}$} \\
\hline \multicolumn{11}{|c|}{ 2. Fresh Feed for MEE } \\
\hline \multicolumn{11}{|c|}{ 3. Production Mono } \\
\hline \multicolumn{11}{|c|}{ 4. Heat Pump Fluid } \\
\hline
\end{tabular}


Table 3A:3. MEE Performance for Heat Pump (LiNO3:KNO3:NaNO2 53:35:12)

\begin{tabular}{|c|c|c|c|c|c|c|c|c|c|c|}
\hline \begin{tabular}{|l} 
Effect \\
Exchanger
\end{tabular} & $\begin{array}{c}\mathrm{U} \\
\text { Btu/ft².hr.R } \\
\end{array}$ & $\begin{array}{c}\text { Area } \\
\mathrm{ft}^{2}\end{array}$ & $\begin{array}{c}\text { UA } \\
\text { Btu/hr.R }\end{array}$ & $\begin{array}{c}\text { Area Calc } \\
\mathrm{ft}^{2} \\
\end{array}$ & \begin{tabular}{|c|} 
Proc Tin \\
${ }^{\circ} \mathrm{C}$ \\
\end{tabular} & \begin{tabular}{|c|} 
Proc Tout \\
${ }^{\circ} \mathrm{C}$ \\
\end{tabular} & $\begin{array}{c}\text { Steam Tin } \\
{ }^{\circ} \mathrm{C}\end{array}$ & $\begin{array}{c}\text { Steam Tout } \\
{ }^{\circ} \mathrm{C}\end{array}$ & $\begin{array}{c}\text { Duty } \\
\text { MMBtu/hr }\end{array}$ & $\begin{array}{c}\text { Steam Gen } \\
\mathrm{lb} / \mathrm{hr}\end{array}$ \\
\hline HE-2501 & 374 & 15,300 & $3,495,739$ & 9,347 & 103.2 & 105.7 & 123.8 & 108.9 & 67.3 & 74,411 \\
\hline HE-2502 & 374 & 15,300 & $4,851,792$ & 12,973 & 87.0 & 88.5 & 96.1 & 96.1 & 72.8 & 94,263 \\
\hline HE-2503 & 374 & 15,300 & $3,147,971$ & 8,417 & 63.7 & 66.2 & 81.9 & 81.9 & 95.5 & 119,022 \\
\hline \multicolumn{11}{|c|}{ 1. Primary Steam Import $\sim 75,697 \mathrm{lb} / \mathrm{hr}$} \\
\hline \multicolumn{11}{|c|}{ 2. Fresh Feed for MEE } \\
\hline \multicolumn{2}{|c|}{ 3. Production Mono } & \multicolumn{9}{|c|}{$\sim 172,375 \mathrm{lb} / \mathrm{hr}$} \\
\hline \multicolumn{11}{|c|}{ 4. Heat Pump Fluid } \\
\hline
\end{tabular}


Figure 3A: 1 ASPEN Process Flow Diagram of MEE Benchmark

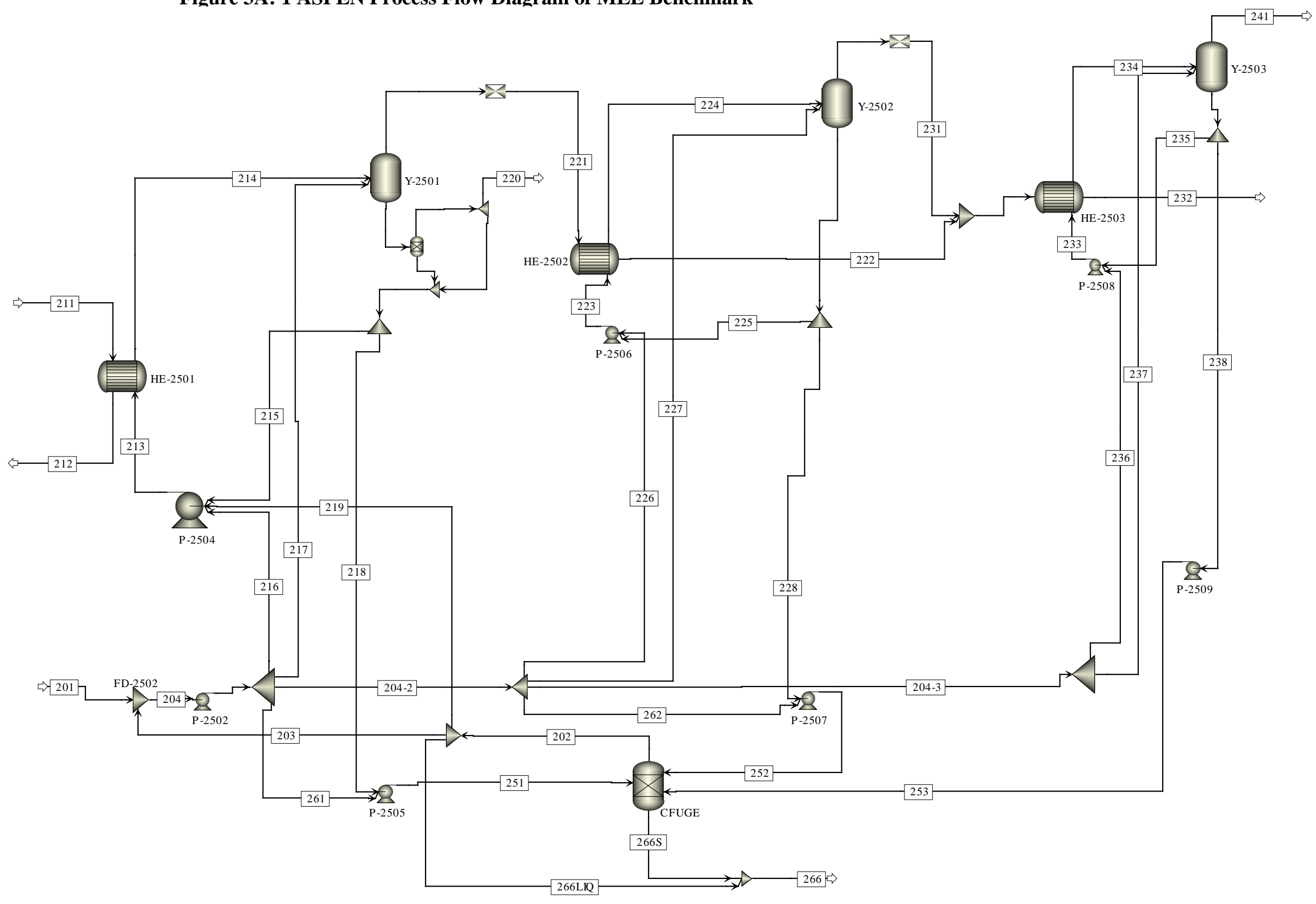


Figure 3A:2 Process Flow Diagram of Soda Ash Triple Effect Evaporation - Closed Cycle Thermal Heat Pump

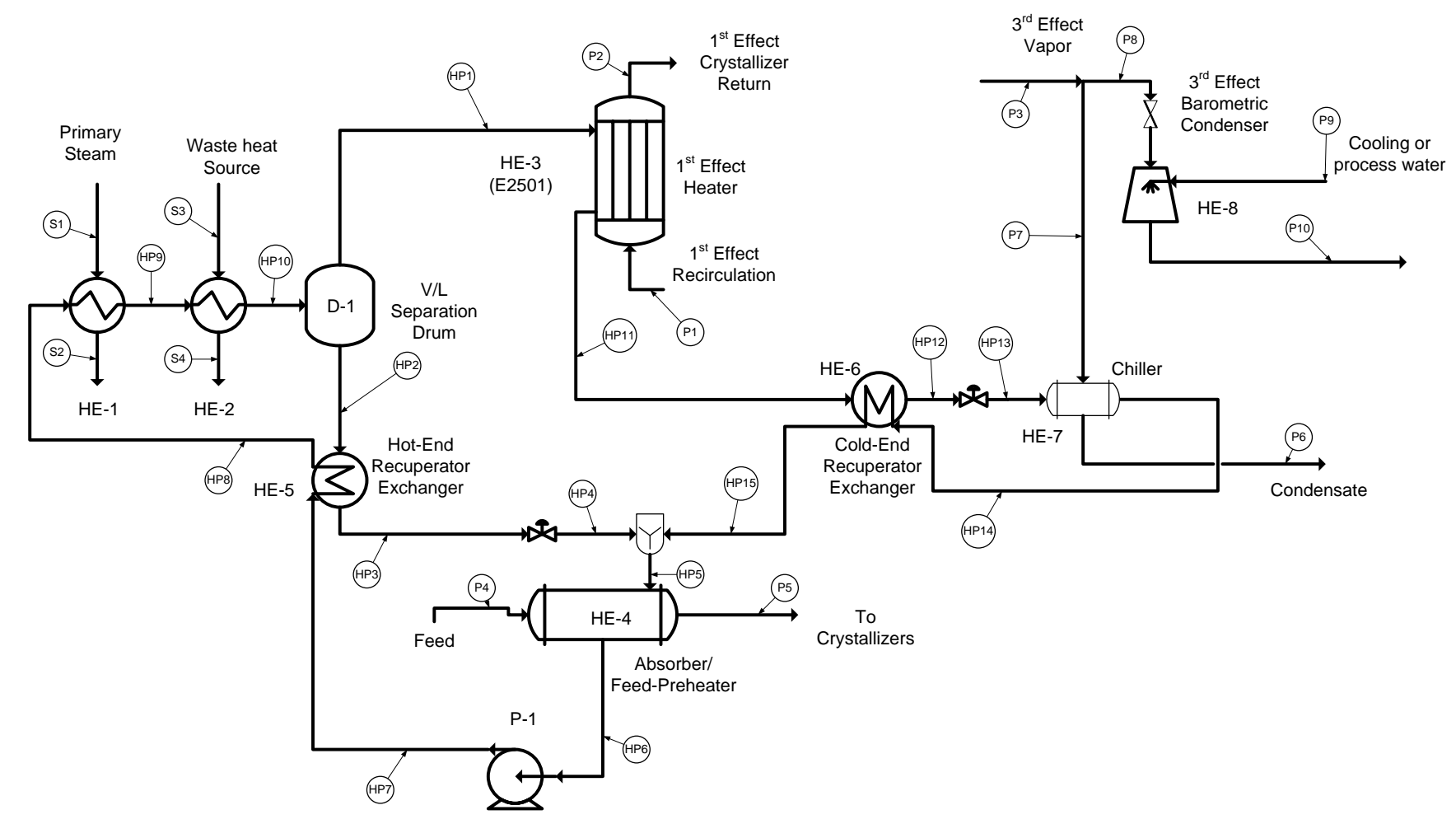


Figure 3B:1 ASPEN+ Flow Sheet for the Benchmark H2O2

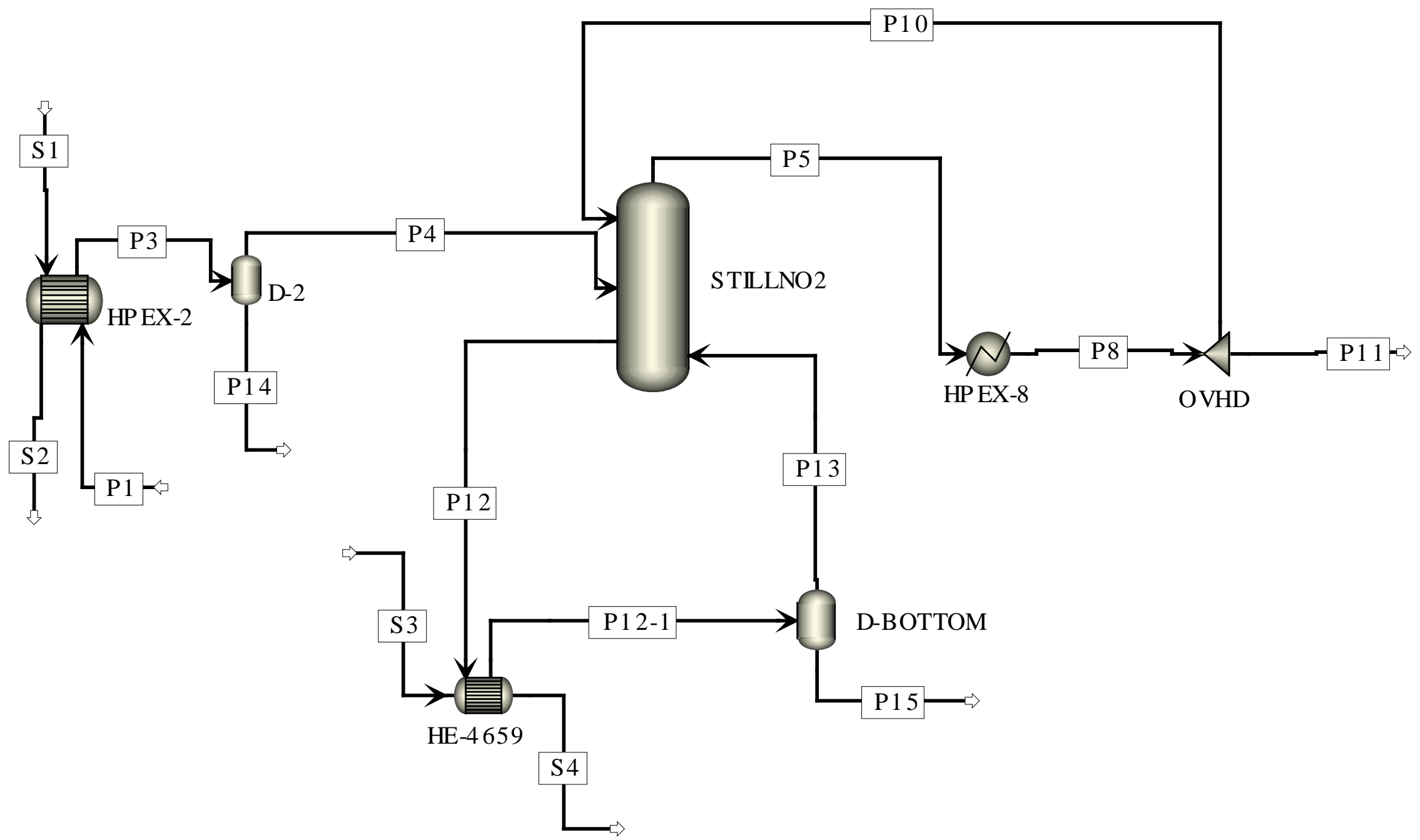




\subsubsection{Task 3B: System Analysis of H2O2 Distillation Process}

The purpose of this task is to analyze a distillation process for the purification of H2O2-water system and compare its performance when coupled to a heat pump for the supply of its heating and cooling utilities. The analysis was done using Aspen, taking into account heat integration in heat exchangers in the heat pump for heat recovery and recycling within the process.

The analysis was carried out based on the two promising heat pump fluids identified in Task 2 of the project: Trifluoroethanol (TFE) + Triethylene Glycol Dimethyl ether (DMETEG) and Ammonia+ Water.

\subsubsection{B.1 H2O2 Benchmark}

Table 3B:1 summarized the current performance of the H2O2 process with 37,926lb/hr (38wt\% H2O2) fresh feed; $27,844 \mathrm{lb} / \mathrm{hr}$ steam for preheating the feed from $45^{\circ} \mathrm{C}$ to $71.8^{\circ} \mathrm{C}$ before flashing for liquid purge and purification of the remaining vapor in the distillation column. The product yield is 9,076lb/hr (71.2wt\% H2O2) with 4,663lb/hr steam for reboiler duty in the distillation column. As shown in Table 3B:1, the exchanger duties are 25.8MMbtu/hr for the preheater (HEXP-2), 4.3MMBtu/hr for the reboiler (HE-4659) and 29.2MMBtu/hr for the condenser (HPEX-8) of the distillation column.

\subsubsection{B.2 H2O2 Performance for Heat Pump (TFE-DMETEG)}

Table 3B:2 summarized the performance of the $\mathrm{H} 2 \mathrm{O} 2$ process for this heat pump. As shown, the feed to the process is maintained at $37,926 \mathrm{lb} / \mathrm{hr}(38 \mathrm{wt} \% \mathrm{H} 2 \mathrm{O} 2)$ and the steam import for heating the feed to $71.8^{\circ} \mathrm{C}$ with the heat pump becomes $15,580 \mathrm{lb} / \mathrm{hr}$. The hot feed is again flashed for liquid purge before feeding the vapor to the distillation column for purification. The product yield for the column is $9,076 \mathrm{lb} / \mathrm{hr}(71.2 \mathrm{wt} \% \mathrm{H} 2 \mathrm{O} 2)$ with 4,627lb/hr steam for the reboiler duty. As further shown in Table 3B:2, the exchanger duties are 11.3MMbtu/hr for the preheater (HEXP-2), 4.3MMBtu/hr for the reboiler (HE-4659) and 18.4MMBtu/hr for the condenser (HPEX-8) of the distillation column. The savings (44\%) in the duty of the preheat exchanger over that of the benchmark is due to the heating of the fresh feed from $45^{\circ} \mathrm{C}$ to $64.1^{\circ} \mathrm{C}$ by the heat pump before further heating in the preheater. Here, the capacity of the process is $9,076 \mathrm{lb} / \mathrm{hr}(71.2 \mathrm{wt} \% \mathrm{H} 2 \mathrm{O} 2)$ which is the same as the benchmark.

The amount of heat pump fluid used for this case was 538,354lb/hr with 53wt $\%$ TFE. The phase equilibria data in the literature for this heat pump fluid was used in the analysis.

\subsubsection{B.3 H2O2 Performance for Heat Pump (Ammonia-Water)}

Table 3B:3 summarized the performance of the H2O2 process for this heat pump. As shown in Table 3B:3, the feed to the process is maintained at $37,926 \mathrm{lb} / \mathrm{hr}(38 \mathrm{wt} \% \mathrm{H} 2 \mathrm{O} 2)$ and the steam import for preheating the feed to $71.8^{\circ} \mathrm{C}$ with the heat pump becomes $15,985 \mathrm{lb} / \mathrm{hr}$. The hot feed is again flashed for liquid purge after the preheater before feeding of the vapor to the distillation column for purification. Again, the product yield for the column is $9,065 \mathrm{lb} / \mathrm{hr}(71.2 \mathrm{wt} \% \mathrm{H} 2 \mathrm{O} 2)$ with 4,665lb/hr steam for the reboiler duty. As shown, the exchanger duties are 9.7MMbtu/hr for the preheater (HEXP-2), 4.3MMBtu/hr for the reboiler (HE-4659) and 18.3MMBtu/hr for the condenser (HPEX-8) of the distillation column. The savings (43\%) in the duty of the preheat exchanger over that of the benchmark is due to the heating of the fresh feed from $45^{\circ} \mathrm{C}$ to $65.1^{\circ} \mathrm{C}$ by the heat pump before further heating in the preheater. Here, the capacity of the process is $9,065 \mathrm{lb} / \mathrm{hr}(71.2 \mathrm{wt} \%$ $\mathrm{H} 2 \mathrm{O} 2$ ), essentially the same as the benchmark.

The amount of heat pump fluid used for this case was 66,939lb/hr with 70wt\% Ammonia. The phase equilibria data in the literature for this heat pump fluid was used in the analysis. 
Table 3B:1. H2O2 Benchmark

\begin{tabular}{|c|c|c|c|c|c|c|c|c|c|}
\hline \begin{tabular}{|l} 
Effect \\
Exchanger
\end{tabular} & $\begin{array}{c}\mathrm{U} \\
\mathrm{Btu} / \mathrm{ft}^{2} . h r . R\end{array}$ & $\begin{array}{c}\text { Area } \\
\mathrm{ft}^{2}\end{array}$ & $\begin{array}{c}\text { UA } \\
\text { Btu/hr.R }\end{array}$ & $\begin{array}{c}\text { Area Calc } \\
\mathrm{ft}^{2}\end{array}$ & $\begin{array}{c}\text { Proc Tin } \\
{ }^{\circ} \mathrm{C}\end{array}$ & $\begin{array}{c}\text { Proc Tout } \\
{ }^{\circ} \mathrm{C}\end{array}$ & $\begin{array}{c}\text { Steam Tin } \\
{ }^{\circ} \mathrm{C}\end{array}$ & $\begin{array}{c}\text { Steam Tout } \\
{ }^{\circ} \mathrm{C}\end{array}$ & $\begin{array}{c}\text { Duty } \\
\text { MMBtu/hr }\end{array}$ \\
\hline HPEX-2 (Preheat) & 250 & 1,200 & 181,427 & 726 & 45.0 & 71.8 & 138.2 & 138.2 & 25.80 \\
\hline HE-4659 (Reboiler) & 400 & 120 & 34,398 & 86 & 64.4 & 72.2 & 138.2 & 138.2 & 4.32 \\
\hline HPEX-8 (Condenser) & & & & & & & 47.0 & 47.0 & 29.18 \\
\hline \multicolumn{10}{|c|}{ 4. $\quad$ Primary Steam $\sim 27,844 \mathrm{lb} / \mathrm{hr}$} \\
\hline \multicolumn{10}{|c|}{ 5. Reboiler Steam $\sim$ 4,663lb/hr } \\
\hline 6. Fresh Feed & \multicolumn{9}{|c|}{ 37,926 lb/hr (38.0wt\% H2O2) } \\
\hline 7. Product & \multicolumn{9}{|c|}{$\sim 9,076 \mathrm{lb} / \mathrm{hr}(71.2 \mathrm{wt} \% \mathrm{H} 2 \mathrm{O} 2)$} \\
\hline
\end{tabular}

Table 3B:2. H2O2 Performance for Heat Pump (TFE-DMETEG)

\begin{tabular}{|c|c|c|c|c|c|c|c|c|c|}
\hline $\begin{array}{l}\text { Effect } \\
\text { Exchanger }\end{array}$ & $\begin{array}{c}\mathrm{U} \\
\mathrm{Btu} / \mathrm{ft}^{2} . h r \cdot \mathrm{R}\end{array}$ & $\begin{array}{c}\text { Area } \\
\mathrm{ft}^{2}\end{array}$ & $\begin{array}{c}\text { UA } \\
\text { Btu/hr.R }\end{array}$ & $\begin{array}{c}\text { Area Calc } \\
\mathrm{ft}^{2}\end{array}$ & $\begin{array}{c}\text { Proc Tin } \\
{ }^{\circ} \mathrm{C}\end{array}$ & $\begin{array}{c}\text { Proc Tout } \\
{ }^{\circ} \mathrm{C}\end{array}$ & $\begin{array}{c}\text { Hot Tin } \\
{ }^{\circ} \mathrm{C}\end{array}$ & $\begin{array}{c}\text { Hot Tout } \\
{ }^{\circ} \mathrm{C}\end{array}$ & $\begin{array}{c}\text { Duty } \\
\text { MMBtu/hr }\end{array}$ \\
\hline HPEX-2 (Preheat) & 250 & 1,200 & 174,618 & 698 & 64.13 & 71.8 & 109.8 & 98.3 & 11.34 \\
\hline HE-4659 (Reboiler) & 400 & 120 & 34,745 & 87 & 64.40 & 72.2 & 137.5 & 137.5 & 4.32 \\
\hline HPEX-8 (Condenser) & & & & & & & 47.0 & 47.0 & 18.37 \\
\hline \multicolumn{10}{|c|}{ 1. Primary Steam $\sim 15,580 \mathrm{lb} / \mathrm{hr}$} \\
\hline 2. Reboiler Steam & \multicolumn{9}{|c|}{$\sim \quad 4,627 \mathrm{lb} / \mathrm{hr}$} \\
\hline 3. Fresh Feed & \multicolumn{9}{|c|}{ 37,926 lb/hr (38.0wt\% H2O2) } \\
\hline 4. Product & \multicolumn{9}{|c|}{$\sim \quad$ 9,065lb/hr (71.2wt\% H2O2) } \\
\hline 5. Heat Pump Flon & $\sim 538,354 \mathrm{lb}$ & $(53 n$ & TFE) & & & & & & \\
\hline
\end{tabular}

Table 3B:3. H2O2 Performance for Heat Pump (Ammonia-Water)

\begin{tabular}{|c|c|c|c|c|c|c|c|c|c|}
\hline \begin{tabular}{|l} 
Effect \\
Exchanger
\end{tabular} & $\begin{array}{c}\mathrm{U} \\
\mathrm{Btu} / \mathrm{ft}^{2} \cdot h r \cdot \mathrm{R}\end{array}$ & $\begin{array}{c}\text { Area } \\
\mathrm{ft}^{2}\end{array}$ & $\begin{array}{c}\text { UA } \\
\text { Btu/hr.R }\end{array}$ & $\begin{array}{c}\text { Area Calc } \\
\mathrm{ft}^{2}\end{array}$ & $\begin{array}{c}\text { Proc Tin } \\
{ }^{\circ} \mathrm{C}\end{array}$ & $\begin{array}{c}\text { Proc Tout } \\
{ }^{\circ} \mathrm{C}\end{array}$ & $\begin{array}{l}\text { Hot Tin } \\
{ }^{\circ} \mathrm{C}\end{array}$ & $\begin{array}{c}\text { Hot Tout } \\
{ }^{\circ} \mathrm{C}\end{array}$ & $\begin{array}{c}\text { Duty } \\
\text { MMBtu/hr }\end{array}$ \\
\hline HPEX-2 (Preheat) & 250 & 1,200 & 293,080 & 1172 & 65.13 & 71.80 & 90.88 & 82.77 & 9.68 \\
\hline HE-4659 (Reboiler) & 400 & 120 & 34,353 & 86 & 64.40 & 72.20 & 138.11 & 138.11 & 4.31 \\
\hline HPEX-8 (Condenser) & & & & & & & 46.98 & 46.98 & 18.34 \\
\hline \multicolumn{10}{|c|}{ 1. $\quad$ Primary Steam $\sim 15,985 \mathrm{lb} / \mathrm{hr}$} \\
\hline 2. Reboiler Steam & \multicolumn{9}{|c|}{$\sim \quad 4,665 \mathrm{lb} / \mathrm{hr}$} \\
\hline 3. Fresh Feed & \multicolumn{9}{|c|}{ 37,926 lb/hr (38.0wt\% H2O2) } \\
\hline 4. Product & \multicolumn{9}{|c|}{$\sim \quad$ 9,065lb/hr (71.2wt\% H2O2) } \\
\hline 5. Heat Pump Flow & \multicolumn{9}{|c|}{$\sim$ 66,939lb/hr (70wt\% Ammonia) } \\
\hline
\end{tabular}




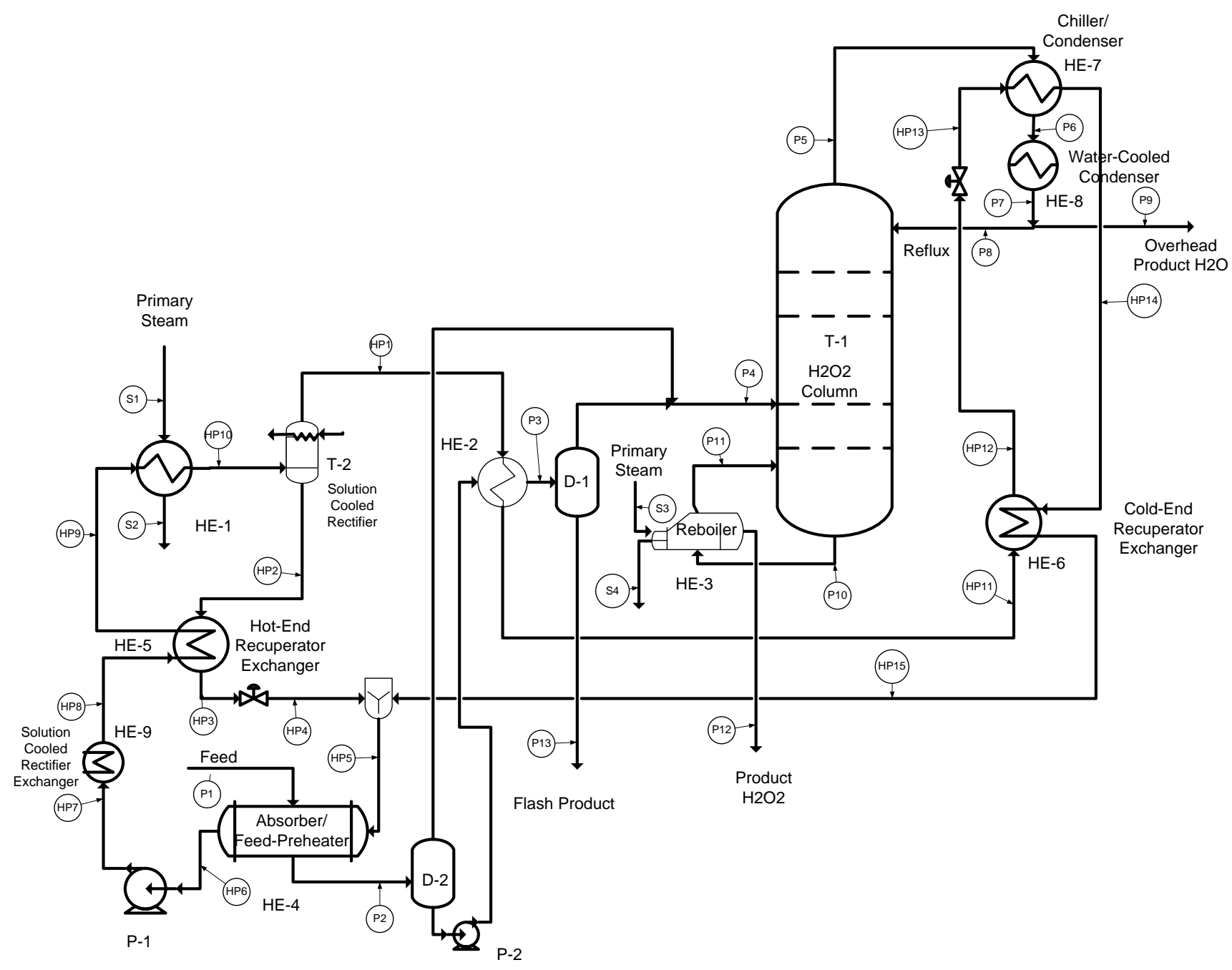

Figure 3B:2 Process Flow Diagram for the combined Heat Pump for H2O2 


\section{Task 4: Conceptual Design of Enhanced Heat Transfer Equipment}

\subsection{Task Objective}

The purpose of this task is to develop design of heat transfer equipment with enhanced performance. High-performance heat transfer equipment is crucial for technical and economic viability of waste heat powered heat pumps. The three groups of heat transfer equipment that require further design developments are for: 1) phase-change heat transfer of mixture working fluids in the heat pump system; 2) recovering latent process heat and transferring back to the process; and 3) recovering waste heat. Candidate enhance performance heat transfer equipment includes twisted tubes, spirally fluted tubes, engineered surfaces, and compact heat exchangers In addition to enhancement, this task will also focus on new and improved design of heat transfer equipment.

\section{Deliverables}

Documentation consists of basic description of conceptual design of enhanced heat exchangers, schematic drawings, and potential vendors, including calculation of potential heat transfer improvements and impact on heat recovery from the Task 3 processes.

\subsection{PFD and Equipment List}

\section{Distillation}

Figure 1 represents $\mathrm{H} 2 \mathrm{O} 2$ distillation process equipped with thermal heat pump. Ammonia-water is shown to be more favorable working fluid than other fluids analyzed in Task 2. Alternate working fluid pair could be TFE/DMETEG (trifluoro ethanol/dimethylether diethylene glycol). The systems analysis (Task 3) shows that steam consumption in the feed heater is $27,844 \mathrm{lb} / \mathrm{hr}$ and $4,663 \mathrm{lb} / \mathrm{hr}$ in the column reboiler. The thermal heat pump is configured to utilize the primary steam and recover optimum fraction of the latent heat from overhead condenser. The thermal heat pump reduces steam consumption by $43 \%$ from $27,844 \mathrm{lb} / \mathrm{hr}$ to $15,985 \mathrm{lb} / \mathrm{hr}$. In order to maintain controllability of the column, primary steam is used in the reboiler. Process conditions and exchanger heat duties are shown in Tables 1 and 2, respectively. Table 3 presents equipment list and design specifications.

\section{Triple-Effect Evaporation (TEE)}

Figures 2 and 3 represent triple-effect soda ash process unit equipped with open and closed cycle thermal heat pumps, respectively. As shown by the systems analysis in Task 3 report, alkalinenitrate+nitrite/water is better working fluid than other fluids evaluated in Task 2 . In the open cycle system part of the water vapor from the third effect is directly absorbed, thereby eliminating two heat exchangers and corresponding costs. Different process configurations were evaluated for the closed cycle and the process flow diagram shown in Figure 3 is found to be suitable for the soda-ash process. Consumption of primary steam for benchmark conditions, with crystallizer feed temperature of $140 \mathrm{~F}$ (60C), is $119,882 \mathrm{lb} / \mathrm{hr}$ for production of $173,217 \mathrm{lb} / \mathrm{hr}$ with the resulting steam economy of 2.42 .

The open cycle heat pump reduces consumption of primary steam at 37.3 psia to 56,249 lb/hr; however, it requires 44,053 lb/hr high pressure (162.7 psia) steam. The steam economy based on the total steam consumption increases to 2.91. In this case, process limitations are implemented; therefore, the open cycle can be implemented with minimum impact on process conditions. If process conditions are allowed to vary beyond limitations considered in this design case, the steam economy would be improved further. Process conditions and exchanger heat duties for open-cycle heat pump are shown in Tables 4 and 5, respectively. Table 6 presents equipment list and design specifications. 
Three process configurations were evaluated of the closed cycle configurations. They were: 1) condenser cooled by the working fluid as shown in Figure 3; 2) the water vapor of working fluid is directly used in the direct contact condenser; and 3) a separate closed loop cooling water loop with cooling provided by the working fluid. A preliminary Aspen+ analysis showed that the process configuration shown in Figure 3 is most suited for the soda ash process. However, in the absence of waste heat source, all of the primary steam would have to be provided at high pressure. In this project the open cycle has been used as the reference design for the soda ash process because it would have techno-economic advantages over the closed cycle. If for any reason the open cycle cannot be used, further design study needs to be performed for an optimized design of the closed cycle thermal heat pump.

\subsection{Description and Performance Enhancement of Heat Transfer Equipment}

The purpose of implementing enhancement is to maintain low approach temperatures between hot and cold process streams to maximize the heat pump efficiency. Figure 4 represents candidate enhancements, with Twisted Tube ${ }^{\circledR}$ as the leading candidate. Swirling flow inside the tube enhances single as well as two-phase flow heat transfer coefficients without significant increase in the pressure drop. Spirally indented tubes enhance the heat transfer performance by disturbing the boundary layer and producing mild swirling flow near the wall. Further enhancement for both types of tubes can be achieved by microfins or porous surface on outside for enhancing condensation and thin-film evaporation. Compact heat exchangers considered for thermal heat pump applications are: a) welded-plate; b) shell-and-coil; and c) brazed plate-fin heat exchangers. Figures 5 and 6 present sectional view of shell-and-coil and plate-fin heat exchangers.

Industrial and academic organizations have been actively pursuing the development of heat transfer enhancements. The discussion below represents highlight of the extensive developments of heat transfer enhancement reported in the literature. With proper understanding of enhancement mechanisms in single as well as in two-phase flow and the development of reliable prediction methods, it is now possible to take full advantages of enhanced thermal performance in energy-efficiency technologies, such the thermal heat pump of this project. Butterworth and Mascone (1991) provided a summary of the developments of new and improved design of heat exchangers for process integration and intensification. Panchal and Rabas (1993) presented a comprehensive study of thermal performances of various enhanced tubes and compact heat exchangers. Jafari Nasr and Polley (2002) presented practical procedure to follow for evaluating benefits of enhancements for a given application. Compact heat exchangers provide high thermal performance and compactness and they are being increasing used in the process industry (Wadekar, 2000). Panchal et al (1997) designed and tested cross-flow aluminum plate-fin heat exchanger for condensing low-pressure steam in the presence of non-condensable gases.

Enhanced tubes have shown to reduce the fouling propensity in cooling water as well as in petroleum processing applications. Panchal and Lubicic (2008) showed that the Twisted Tubes ${ }^{\circledR}$ can significantly enhanced flow boiling in reboilers and reduce the fouling propensity. Rabas et al. (1993) analyzed the field data of a utility condenser and showed that spirally indented tubes can maintain high performance for extended period of time. Panchal et al (2004) conducted field tests to show that spirally indented tubes and tube inserts can significantly reduce the fouling propensity of crude oil.

An Excel-based performance analysis is carried out for each of the heat transfer equipment. An illustrative calculation procedure is shown in Table 7 for H2O2 HE-1. Appropriate heat transfer correlations are used for calculating individual heat transfer coefficients. Process parameters derived from the Aspen+ systems analysis are used in the heat exchanger performance analysis. 


\section{Distillation Process}

Table 3 presents the basic design parameters of exchangers. In order to minimize the technical risks, shell-and-tube heat exchangers are used, except for heat pump recuperators.

HE-1 Ammonia Vapor Generator: Unit is shell-and-tube (TEMA BXU or Hairpin design) exchanger equipped with either Twisted Tubes ${ }^{\circledR}$ with micro-fins on outside. It has two tube side passes using U-tube configuration. Twisted Tubes provide swirling flow enhancement of in-tube flow boiling of ammonia-water mixture. Micro-fins provide significant, greater than factor of two, surface-tension driven enhancement of condensation of steam on outside of tubes.

HE-2 Feed heater: Unit is shell-and-tube (TEMA BX shell) exchanger equipped with either Twisted Tubes ${ }^{\circledR}$ with micro-fins on outside. Twisted Tubes provide swirling flow enhancement of intube flow condensation of ammonia. Micro-fins provide significant, greater than factor of one and half, surface-tension driven enhancement of thin-film evaporation of $\mathrm{H} 2 \mathrm{O} 2 / \mathrm{H} 2 \mathrm{O}$ feed on outside of tubes.

HE-3 Reboiler: Maintain the original design

HE-4 Heat Pump Absorber/Feed Preheater: Unit is shell-and-tube (TEMA BXM shell) exchanger with four tube-side passes and equipped with Twisted Tubes ${ }^{\circledR}$ with micro-fins on outside. Twisted Tubes ${ }^{\circledR}$ provide swirling flow enhancement of in-tube forced convective absorption of ammonia vapor into ammonia-water solution. Micro-fins provide significant, greater than factor of one and half, surface-tension driven enhancement of thin-film evaporation of $\mathrm{H} 2 \mathrm{O} 2 / \mathrm{H} 2 \mathrm{O}$ feed on outside of tubes.

HE-5 Hot-End heat Pump Recuperator: Unit is welded plate heat exchanger with high-performance plate geometry providing enhancement of single-phase heat transfer.

HE-6 Cold-End heat Pump Recuperator: Unit is shell-and-coil heat exchanger equipped with spirally indented tubes. Helically coiled nested tubes provide significant enhancement of single-phase ammonia liquid in-tube flow. The cross-flow over helically coiled tube bundle provides effective heat transfer to the ammonia vapor with some liquid carry over from the chiller/condenser.

HE-7 Heat Pump Chiller/Condenser: Unit is shell-and-tube (TEMA BXU shell) exchanger equipped with Twisted Tubes ${ }^{\circledR}$ with microfins on outside. It has two tube side passes using U-tubes. Twisted Tubes ${ }^{\circledR}$ provide swirling flow enhancement of in-tube forced convective evaporation of ammonia. Micro-fins provide significant, greater than factor of one and half, surface-tension driven enhancement of condensation of the overhead vapor.

HE-8 Overhead Water-Cooled Condenser: Maintain the original design.

HE-9 Solution-Cooled Reflux Condenser for Ammonia Rectifier: This unit will be a custom design compact heat exchanger to be installed in the top section of the rectifier. Coolant is ammoniawater mixture from the absorber.

\section{Triple-Effect Evaporation (TEE)}

\section{Open Cycle Heat Pump}

Table 6 presents the basic design parameters of exchangers. In order to minimize the technical risks, shell-and-tube heat exchangers are used, except for heat pump recuperator.

HE-1 Vapor Generator: The unit is shell-and-tube (TEMA BXU or Hairpin design) exchanger equipped with either Twisted Tubes ${ }^{\circledR}$ with micro-fins on outside. It has two tube side passes using Utubes. Twisted Tubes ${ }^{\circledR}$ provide swirling flow enhancement of in-tube forced convective boiling alkaline nitrate-water mixture. Micro-fins provide significant, greater than factor of one and half, surface-tension driven enhancement of condensation of steam.

HE-3 Crystallizer Heater: Existing plain tube heat exchanger

HE-4 Heat Pump Absorber/Feed Preheater: The unit is shell-and-tube (TEMA BXM shell) exchanger with four tube-side passes and equipped with Twisted Tubes ${ }^{\circledR}$ with micro-fins on outside. Twisted Tubes ${ }^{\circledR}$ provide swirling flow enhancement of single-phase flow of soda ash crystallizer 
feed. Micro-fins provide significant, greater than factor of one and half, surface-tension driven enhancement of thin-film absorption of water vapor into concentrated alkaline nitrate solution flowing over on outside of tubes.

HE-5 Hot-End heat Pump Recuperator: Unit is welded plate heat exchanger with high-performance plate geometry providing enhancement of single-phase heat transfer.

\section{Closed Cycle Heat Pump}

In order to minimize the technical risks, shell-and-tube heat exchangers are used, except for heat pump recuperator.

Design of HE-1, HE-4 and HE-5 would be similar to that for the open cycle, except for size and heat duty. Design specifications for the two additional heat exchangers are given here.

HE-6 Cold-End Heat Pump Recuperator: Unit is shell-and-tube heat exchanger (AAE Hairpin design) equipped with spirally indented tubes. Twisted Tubes ${ }^{\circledR}$ provide swirling flow enhancement of single-phase flow on both sides. The Hairpin design provides a true counter current flow with high thermal effectiveness.

HE-7 Heat Pump Chiller/Condenser: Unit is brazed aluminum plate-fin heat exchanger with either cross flow or parallel flow configuration depending on pressure drop limitations of low-pressure steam condensation. Serrated or wavy fins would significantly enhance evaporation as well as condensation heat transfer coefficient.

\section{Crystallizer Heaters}

Performance enhancement of crystallizer heaters HE-2501, HE-2502, and HE-2503 can be achieved by retubing them with Twisted Tubes ${ }^{\circledR}$ or spirally indented tubes. Alternatively, tube inserts, shown in Figure 4, can be implemented. The major benefits of implementation of heat transfer enhancement in crystallizer heaters are as follows.

$>$ Reduce temperature difference between heating steam or vapor and recirculation process fluid of soda ash solution;

$>$ Crystallizer pressures can be lowered for $1^{\text {st }}$ and $2^{\text {nd }}$ effect crystallizers, which would increase steam generation and improve steam economy;

$>$ Fouling propensity can be reduced due to swirling flows and lower wall temperatures that induce crystallization of non-process elements;

$>$ Reduce primary steam pressure; and

$>$ By reducing $1^{\text {st }}$ and $2^{\text {nd }}$ effect crystallizers, technical and economic viability of the thermal heat pump significantly improves.

The benchmark analysis shows that design steam economy is about 2.42. However, in normal operation the steam economy would be lower due to the thermal performance and fouling of heat transfer equipment. Log-mean temperature differences (LMTD) of the evaporative crystallizers vary between $10^{\circ} \mathrm{C}$ and $25^{\circ} \mathrm{C}$, depending on recirculation rates, fouling, and the effectiveness of removal of noncondensable gases. By enhancing the thermal performance and reducing the fouling propensity of the three heat exchangers, LMTDs would be reduced with resulting effects on lowering the pressure of the primary steam from 37.3 psia to a lower value. The primary steam source is generally exhausts from the last-stage of steam turbine. Therefore, by lowering the steam pressure power generation is increased. Alternatively, the production rate can be increased with existing heat transfer equipment, provided there is no bottleneck with other process equipment, such as demister vapor velocity limit and pump capacities. The systems analysis showed that by considering refurbishing the three heat exchangers with twisted tubes that would enhance the thermal performance and reduce the fouling propensity. The focus of the steam-economy analysis was on reducing the primary-steam pressure. The heat transfer analysis showed that Twisted Tubes ${ }^{\circledR}$ would enhance the process side heat transfer coefficient by a factor of 1.6 and the effective fouling (fouling on process side and the adverse effects of non-condensable gases on steam side) can be reduced by at least one-half. The effective improvements in the thermal performance of three heat exchangers have potential to reduce pressure of the primary steam from 37.3 psia to 22.4 psia. This 
reduction in steam pressure would increase the power generation by $2 \%$ to $3 \%$. For a steam plant with a typical conversion efficiency of 30\%, additional power generation would be about $350 \mathrm{~kW}$ for primary steam flow rate of 119,882 lb/hr. By enhancing thermal performances of three heat exchangers, crystallizer temperatures are lowered by $8.5^{\circ} \mathrm{C}$ and $3.7^{\circ} \mathrm{C}$ in first and second effect, respectively. That would reduce fouling propensity with further improvement in the energy efficiency.

\subsection{Modifications to TEE Performance}

The process parameters were recalculated using Excel-based method and by maintaining the overall parameters that affect the TEE performance the same as Aspen+ results.

Modifications are as follows:

a. Increased concentration of alkaline nitrate to 82\%; from literature review, the concentration of alkaline nitrate can be increased to about $84 \%$.

b. At this concentration, T-equilibrium of process stream HP5 is $216^{\circ} \mathrm{F}$

c. Concentration does not change significantly between process stream HP4 and HP5, because very little vapor has to be absorbed to increase fluid temp (heat absorption > latent heat of steam).

d. The feed can be heated to $208 \mathrm{~F}$ by keeping the same approach temp of $8^{\circ} \mathrm{F}$ as used before, which is somewhat tight, but it can be done with enhanced-tube heat exchangers.

e. In order to keep the same rate of heat transfer, so we can maintain the TEE performance as predicted by Aspen+, we have to allow some vapor generation in the feed, about $2.5 \%$, since small fraction of vapor is allowed in the feed.

f. $\quad$ Because the alkaline concentration is increased, HP steam pressure would go up. It is now 211.6 psia (200 psig).

The above modifications to the Aspen + results are presented in the updated Table 4 .

This analysis shows that it would be difficult to recover latent heat and recycle to the $1^{\text {st }}$ effect of the soda ash TEE process. It may be better to provide additional vapor/heat to $2^{\text {nd }}$ or $3^{\text {rd }}$ effect; however, that will require major adjustments of process parameters and may require equipment modifications. It cannot be done in a retrofitting design basis just to reduce steam consumption. It has to be part of revamping of the system for increased throughput plus energy efficiency.

\subsection{Further Explanations on How HE-4 Heat Exchanger Works}

Here is a further explanation of operation of HE-4, which requires customized design.

HE-4 is designed as falling film absorber with liquid being sprayed in the vapor space on shell side at the top to reach thermodynamic equilibrium.

Absorption of vapor causes the liquid temp to increase before touching the first row of tubes due to high heat of absorption. In the PFD, this mixing is shown outside HE-4.

As the working fluid solution flows down as thin film it is being cooled by the crystallizer feed. As the solution is cooled more vapor would be absorbed as per the thermodynamic equilibrium. By the time the mixture reached to the bottom of HE-4, all vapor should be absorbed for pumping to a high pressure by pump P-1. For an effective heat transfer, tube side is 4-pass design that also helps to maintain high velocity.

It is noted that the way Aspen+ analysis was performed; it did not handle the heat exchangers streams very well especially those involving HE-4. HP4 is concentrated and cooled and it can absorb fraction of vapor and thereby increase temperature to $230 \mathrm{deg} \mathrm{F}$ as shown in the Table 4 (this is the bottom-line principle of the absorption heat pump system). That way we can heat the feed to 222 deg F. HE-4 is 
customized design as it is commonly done for NH3-H2O absorption refrigeration system; however, there are no thermal performance data for aqueous system.

Table 1. Hydrogen Peroxide Distillation Process Parameters

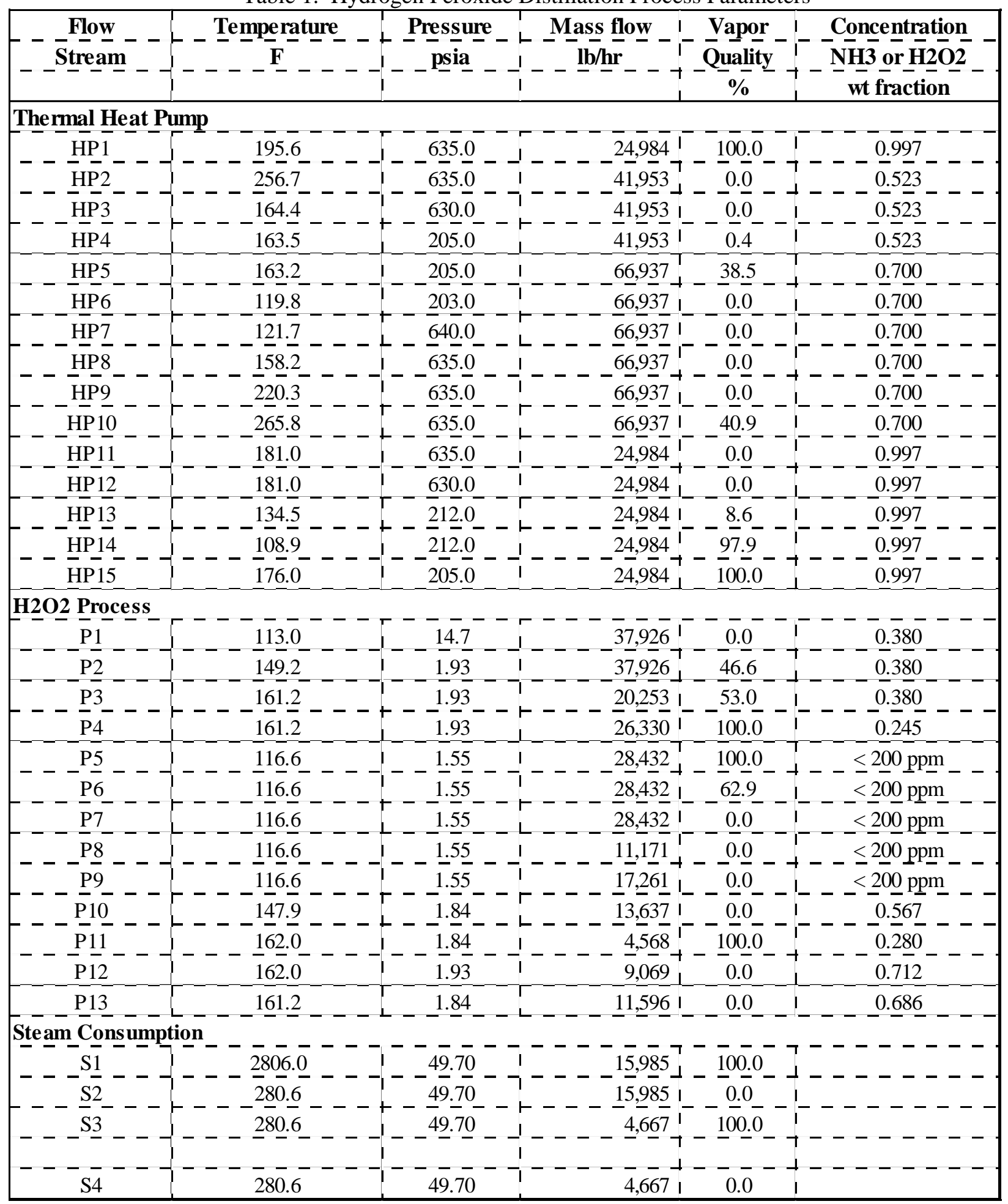


Table 2. Hydrogen Peroxide Distillation Heat Exchanger Duty

\begin{tabular}{|c|c|}
\hline$-\frac{\text { Name }}{\text { Tag }}-+$ & Equipment $\ldots$ - $\ldots \ldots-\ldots$ \\
\hline & 1 \\
\hline $\begin{array}{r}\mathrm{HE}-1 \\
-\frac{\mathrm{HE}-2}{\mathrm{HE}-3}-+ \\
-\frac{\mathrm{HE}}{\mathrm{HE}}-\mathbf{1} \\
-\mathrm{HE}-5\end{array}$ & 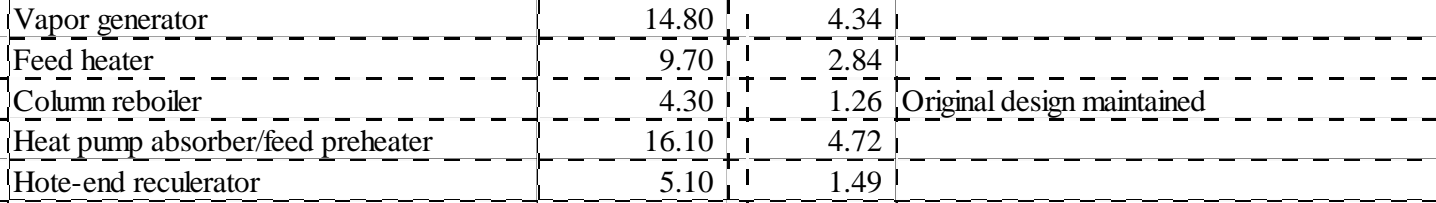 \\
\hline $\begin{array}{l}-\frac{\mathrm{HE}-6}{\mathrm{HE}-7}-\frac{1}{1} \\
-\frac{\mathrm{HE}-8}{-1} \\
-\underline{\mathrm{HE}-9}-\frac{1}{1}\end{array}$ & 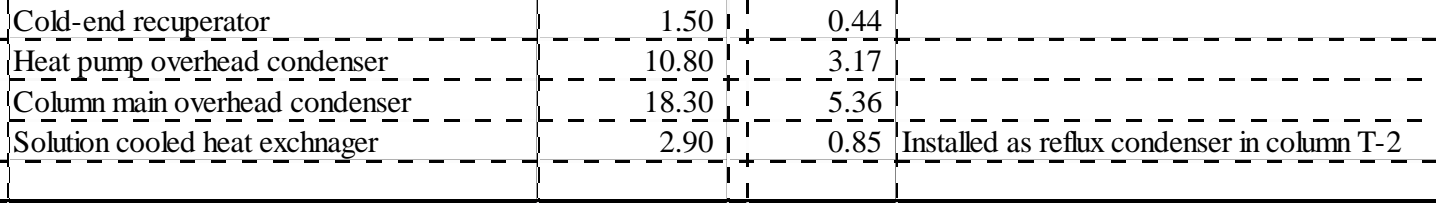 \\
\hline
\end{tabular}


Table 3. Hydrogen Peroxide Heat Exchanger Design Specifications

\begin{tabular}{|c|c|c|c|c|c|c|c|c|c|c|c|c|c|c|}
\hline Tag No. & Service $-\cdots---$ & Exchanger Type & Enhancement & $\begin{array}{l}\text { TEMA Type - } \\
\text { (S\&T only) }\end{array}$ & $\begin{array}{l}\mid \text { Shell/Hot side } \\
\text { Des. P Min }\end{array}$ & é por plate & Oper. $\mathrm{P}$ in & Oper. $\mathrm{T}$ in & HDMT & Mne-li & Tube & Tube lengtht $\mathrm{ft}$ & Painting- & Remark - . . - - \\
\hline \multirow[t]{3}{*}{ PFD Drawing Number } & ---------- & Duty (MMBtu/h) & ------- & Pusses - - - - & Tube/Cold side & de for plate & Oper.P out & Oper. T out & (Shell/Hot) & Ghannel- & Frame - & Tube Dia, in & Insulation & --------- \\
\hline & -1 & $--\cdots$ & & \#Required - & Des. & $\begin{array}{l}\text { Des.T. } \\
\text { Des. TMax } \\
\end{array}$ & $\begin{array}{l}\text { Oper. } \overline{\text { in }}- \\
\text { Oper. P out }\end{array}$ & $\begin{array}{l}\text { Oper. Tin } \\
\text { Oper. T out }\end{array}$ & 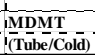 & Plate- coil- & Insulation & Sheili_ Dia., ft-_t & & - \\
\hline & & MM Btu/hr & & & psig & $\mathrm{F}$ & psig & $\mathrm{F}$ & $\mathrm{F}$ & & & & & \\
\hline \multirow{3}{*}{ HE-1 } & Ammonia vapor generator & Shell and tube & Twisted Tubes & BXU or Hairpin & $100 / \mathrm{FV}$ & Amb & 49.7 & 281.0 & & CS & CS & 15.0 & & \\
\hline & & & $\begin{array}{l}\text { Tube side: swirling flow } \\
\text { evaporation }\end{array}$ & 2 Tube Side & & 300 & & 281.0 & & & & 1.0 & Hot & \\
\hline & & 14.8 & $\begin{array}{l}\begin{array}{l}\text { Shell side: micro fin } \\
\text { condensation }\end{array} \\
\end{array}$ & 749 & $750 / \mathrm{FV}$ & Amb & 640 & 220.0 & & & & & & \\
\hline H2O2 Heat Pump & & & & 1 & & 300 & & 266.0 & & & & 3.1 & & \\
\hline \multirow[t]{3}{*}{$\mathrm{HE}-2$} & Feed heater & Shell and tube & Twisted Tubes & BXM & $750 / \mathrm{FV}$ & Amb & 1.93 & 149.2 & & $\mathrm{CS}$ & CS & & & \\
\hline & & & $\begin{array}{l}\text { Tube side: swirling flow } \\
\text { condensation }\end{array}$ & Single Pass & & 300 & & 161.2 & & & & & Hot & \\
\hline & & 9.7 & $\begin{array}{l}\text { Shell side: micro-fin falling } \\
\text { film evapooration }\end{array}$ & 473 & $100 / \mathrm{FV}$ & Amb & 635 & 195.6 & -28 & & & & & \\
\hline H2O2 Heat Pump & & & & 1 & & 300 & & 181.0 & & & & & & \\
\hline \multirow[t]{3}{*}{$\mathrm{HE}-3$} & Reboiler & Shell and tube & & & & & 49.7 & 280.6 & & & & & & \begin{tabular}{|l} 
Existing Design \\
\end{tabular} \\
\hline & & & & & & & & 280.6 & & & & & & \\
\hline & & 4.3 & & & & & 1.84 & 147.9 & & & & & & \\
\hline H2O2 Heat Pump & & & & 1 & & & & 162.0 & & & & & & \\
\hline \multirow[t]{3}{*}{ HE-4 } & $\begin{array}{l}\text { Ammonia absorber/feed } \\
\text { preheater }\end{array}$ & Shell and tube & Twisted Tubes & BXM & $750 / \mathrm{FV}$ & Amb & 14.7 & 113.0 & & $\mathrm{CS}$ & CS & & & \\
\hline & & & $\begin{array}{l}\text { Tube side: swirling flow } \\
\text { absorption }\end{array}$ & Tube side: 4-pass & & 300 & & 149.2 & & & & & Hot & \\
\hline & & 16.1 & $\begin{array}{l}\text { Shell side: micro-fin falling } \\
\text { film evapooration }\end{array}$ & 2019 & $100 / \mathrm{FV}$ & Amb & 205 & 163.2 & & & & & & \\
\hline H2O2 Heat Pump & & & & 1 & & 300 & & 119.8 & & & & & & \\
\hline \multirow[t]{3}{*}{ HE-5 } & Hot-End Heat Pump & Welded Plate & High Performance & & $750 / \mathrm{FV}$ & $\mathrm{Amb}$ & 635 & 256.7 & & & & & & \\
\hline & Recuperator & & Plates & & & 300 & & 164.4 & & & & & & \\
\hline & & 5.1 & & 313 & $750 / \mathrm{FV}$ & $\mathrm{Amb}$ & 645 & 121.7 & & NA & SS-316L & & Hot & \\
\hline H2O2 Heat Pump & & & & 1 & & 300 & & 158.2 & & & & & & \\
\hline \multirow[t]{3}{*}{ HE-6 } & Cold-End Heat Pump & Shell and Coil & $\begin{array}{l}\text { Tube side: helically coiled } \\
\text { tubes with enhancement }\end{array}$ & $\mathrm{NA}$ & $300 / \mathrm{FV}$ & Amb & 630 & 181.0 & -28 & ss & SS & & & \\
\hline & Recuperator & & \begin{tabular}{|l} 
Shell side: cross flow \\
across coiled tubes
\end{tabular} & & & 300 & & 134.5 & & & & & & \\
\hline & & 1.5 & & 734 & $750 / \mathrm{FV}$ & $\mathrm{Amb}$ & 212 & 108.9 & -28 & & & & Hot & \\
\hline H2O2 Heat Pump & & & & 1 & & 300 & & 176.0 & & & & & & \\
\hline \multirow[t]{3}{*}{ HE-7 } & Chiller/Condenser & Shell and Tube & Twisted Tubes & BXU or Hairpin & Atm/FV & Amb & 1.55 & 116.6 & & & & & & \\
\hline & & & $\begin{array}{l}\text { Tube side: swirling flow } \\
\text { evaporation }\end{array}$ & 2 Tube Side & & 300 & & 116.5 & -28 & & & & & \\
\hline & & 10.8 & \begin{tabular}{|l}
$\begin{array}{l}\text { Shell side: Micro-fin } \\
\text { condensation }\end{array}$ \\
\end{tabular} & 887 & $300 / \mathrm{FV}$ & Amb & 212 & 100.2 & & & & & Hot & \\
\hline H2O2 Heat Pump & & & & 1 & & 300 & & 108.9 & & & & & & \\
\hline \multirow[t]{3}{*}{ HE-8 } & Water Cooled Condenser & Shell and Tube & & & & & 1.55 & 116.5 & & & & & & \begin{tabular}{|l|} 
Existing Condenser \\
\end{tabular} \\
\hline & & & & & & & & 116.5 & & & & & & \\
\hline & & 18.3 & & & & & & $\mathrm{NA}$ & & & & & Hot & \\
\hline H2O2 Heat Pump & & & & 1 & & & & $\mathrm{NA}$ & & & & & & \\
\hline \multirow[t]{3}{*}{ HE-9 } & Solution Cooled & Coiled tubes & Helically coiled tubes & & & & & $\mathrm{NA}$ & & & & & & \\
\hline & \begin{tabular}{|l} 
Rectifier Exchanger \\
\end{tabular} & & installed in the rectifier & & & & & NA & & & & & & \\
\hline & & 2.9 & & & $750 / \mathrm{FV}$ & & 640 & 121.7 & & & & & None & \\
\hline H2O2 Heat Pump & & & & 1 & & & 635 & 158.2 & & & & & & \\
\hline
\end{tabular}


Table 4. Triple Effect Open Cycle Process Parameters

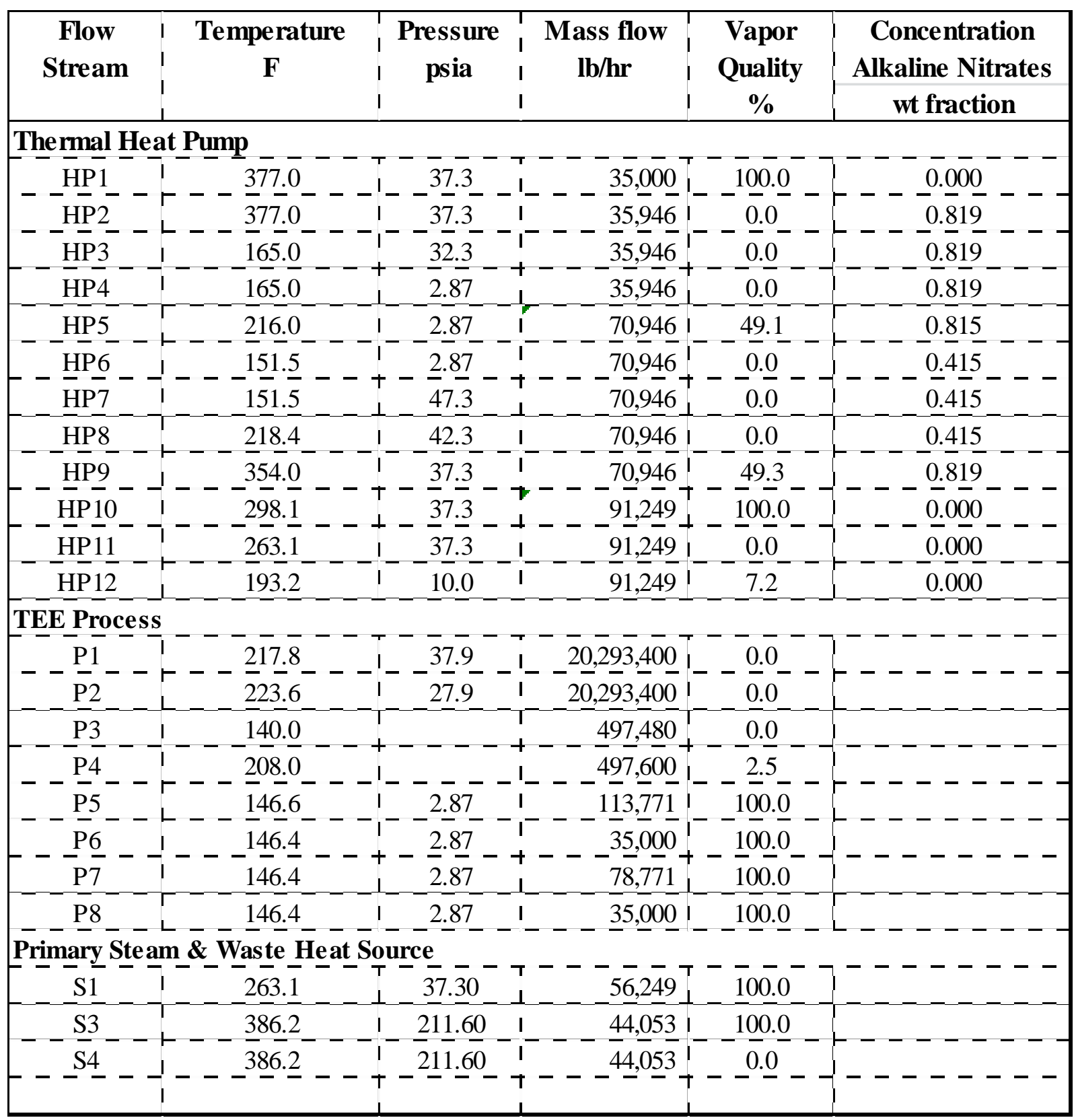


Table 5. Triple Effect Open Cycle Heat Exchanger Duty

\begin{tabular}{|c|c|c|}
\hline$-\frac{\text { Name }}{\text { Tag }}-$ & 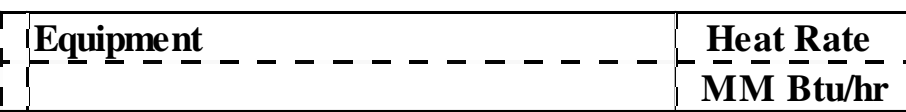 & + Heat Rate \\
\hline & 1 & \\
\hline$-\frac{\mathrm{HE}-1}{\mathrm{HE}-4}-\underline{\mathrm{HE}}-\underline{5}$ & 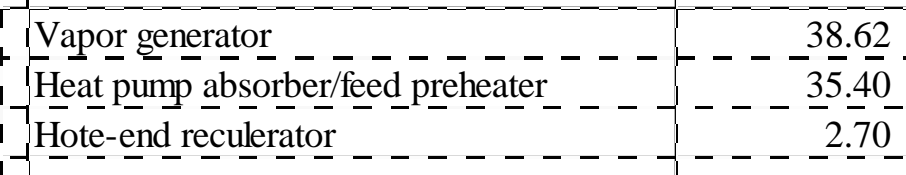 & $\begin{array}{r}11.31 \\
-10.37 \\
-\underline{0 .} .7 \underline{9}\end{array}$ \\
\hline
\end{tabular}

Table 6. Triple Effect Open Cycle Heat Exchanger Design Specifications

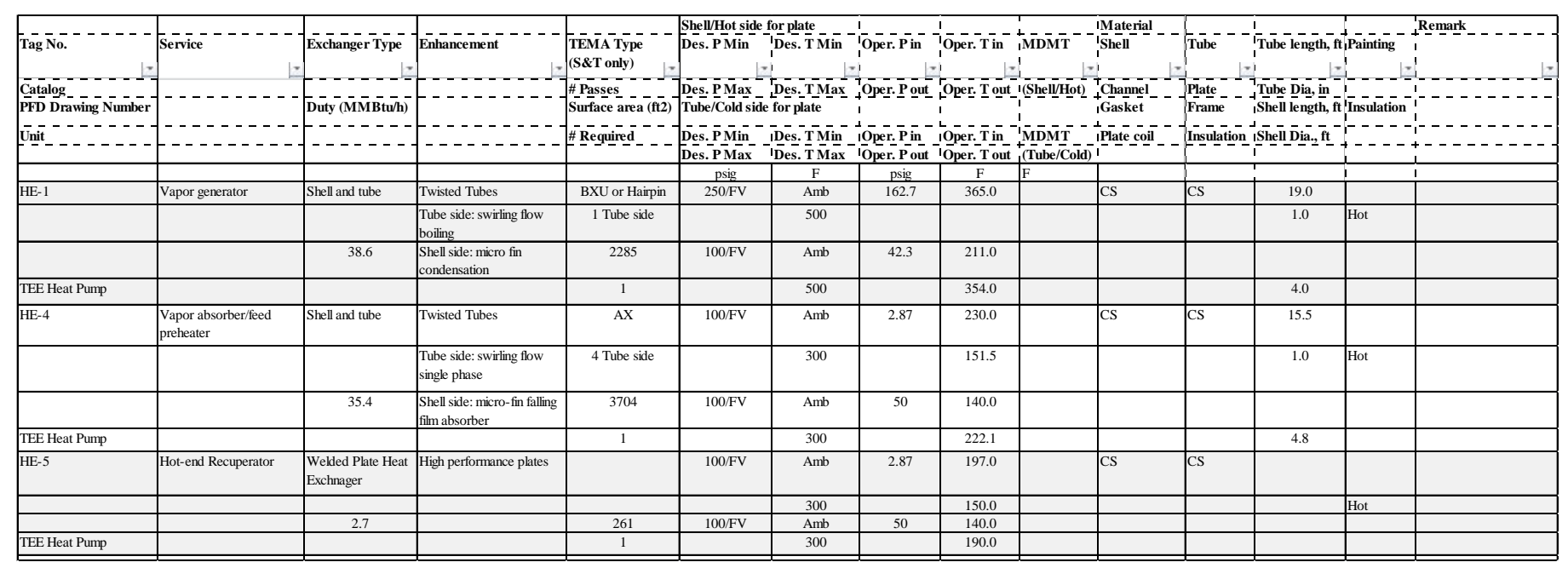


Table 7. Heat Pump Performance Analysis of Heat Transfer Equipment

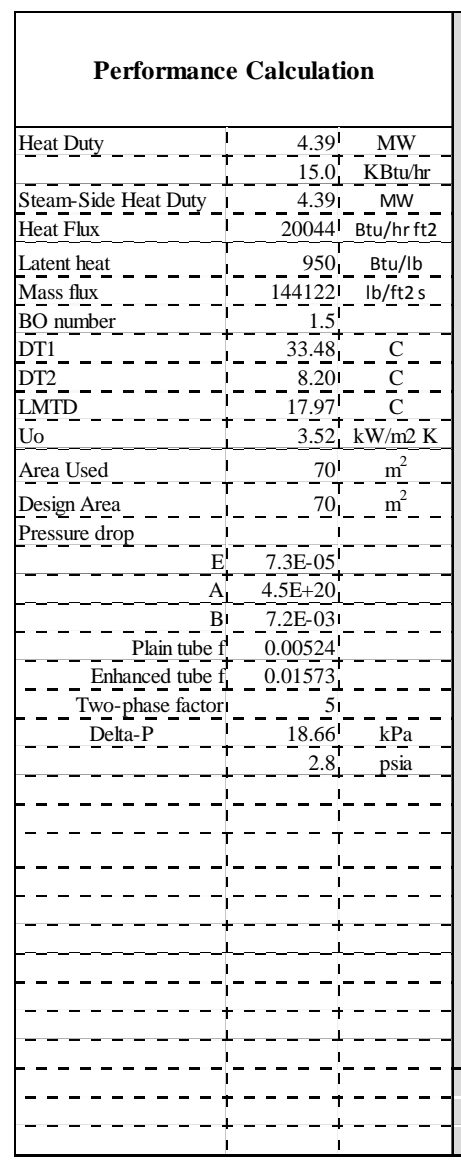

\begin{tabular}{|l|l|} 
& \\
& \\
&
\end{tabular}

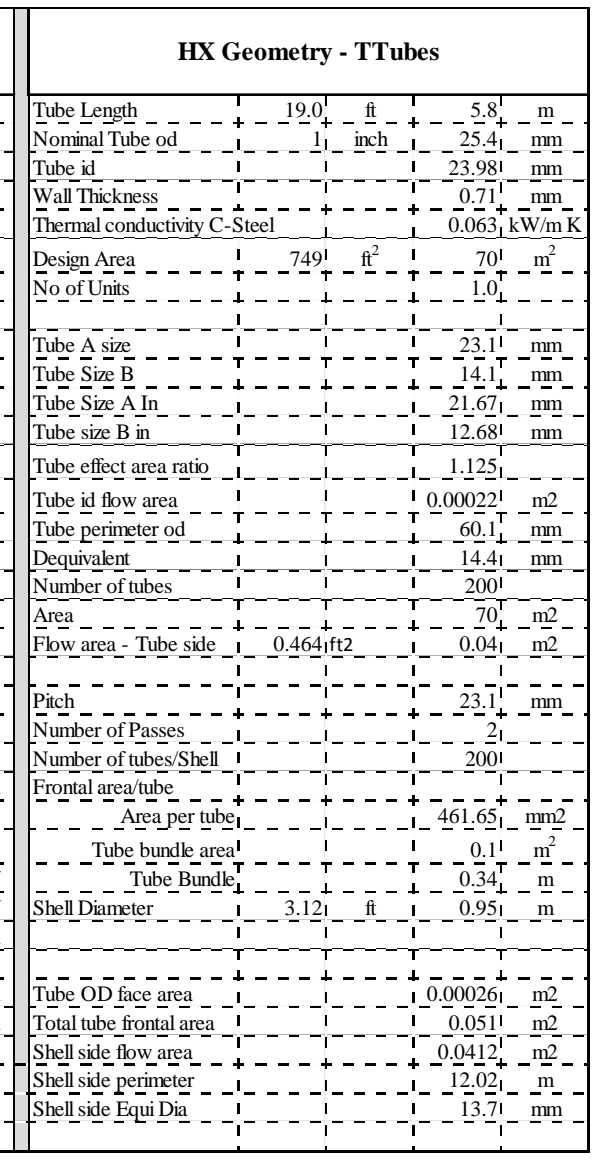




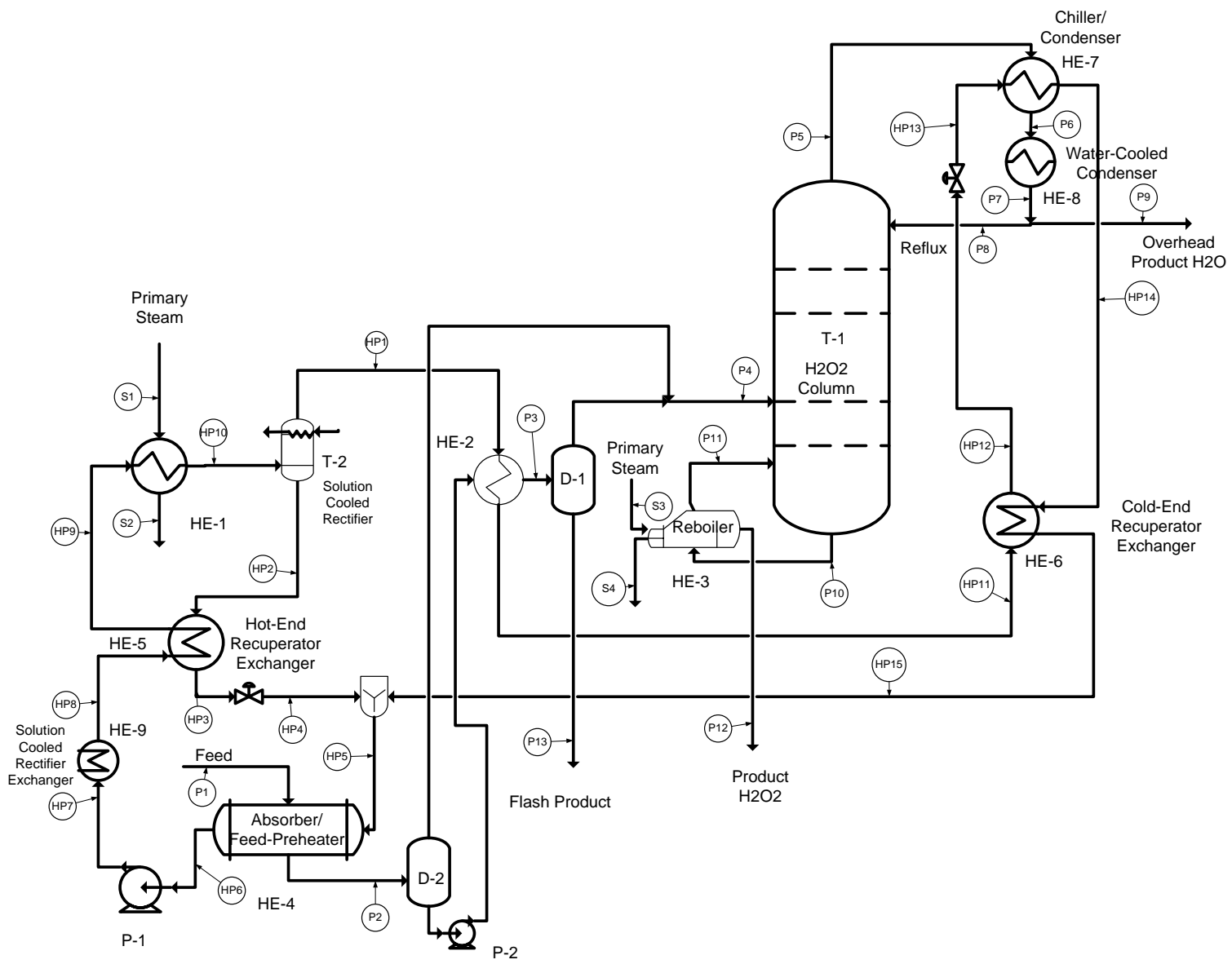

Figure 1. Process Flow Diagram of Hydrogen Peroxide Distillation 


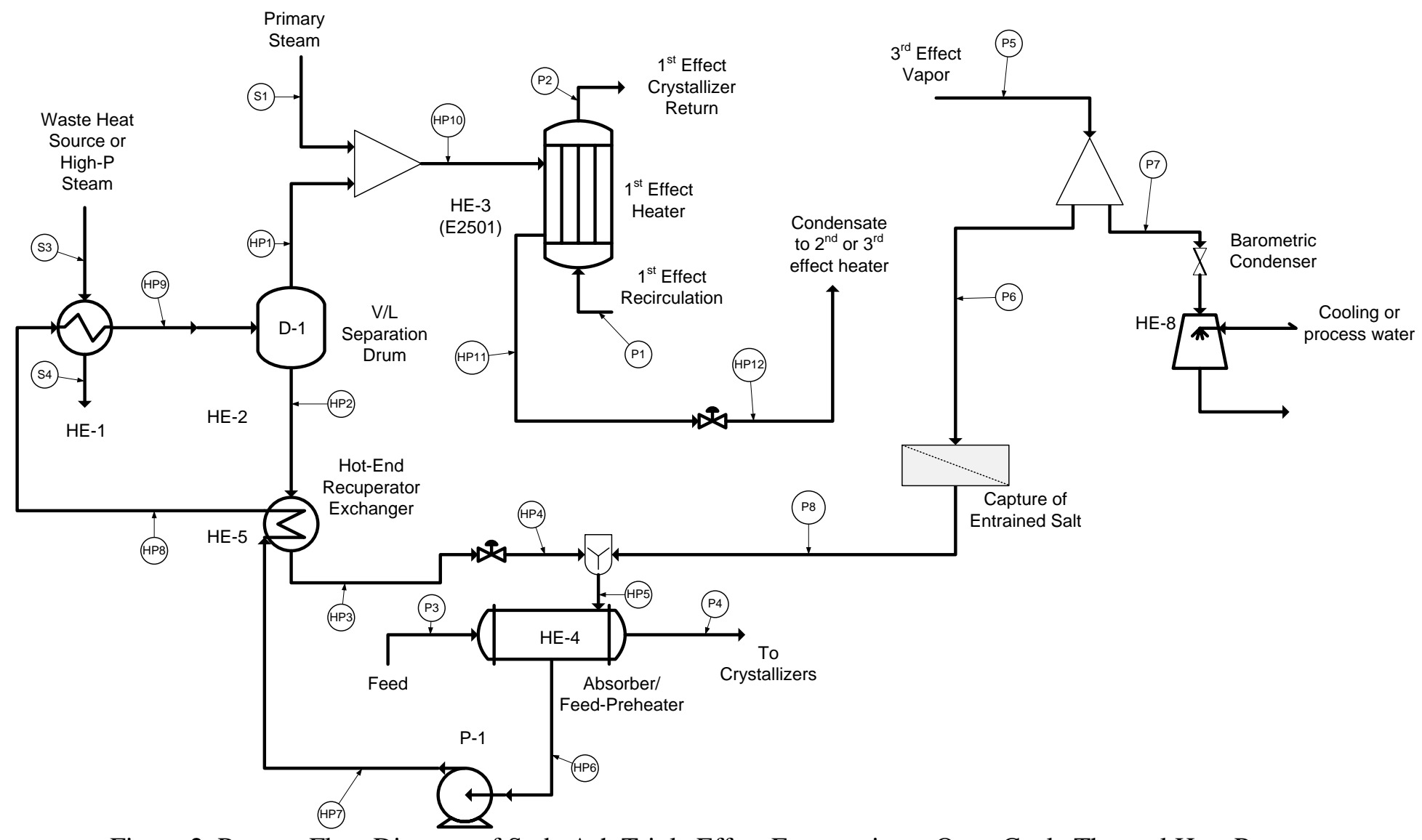

Figure 2. Process Flow Diagram of Soda Ash Triple Effect Evaporation - Open Cycle Thermal Heat Pump 


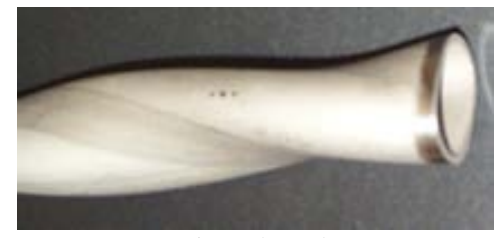

Twisted Tube ${ }^{\circledR}$

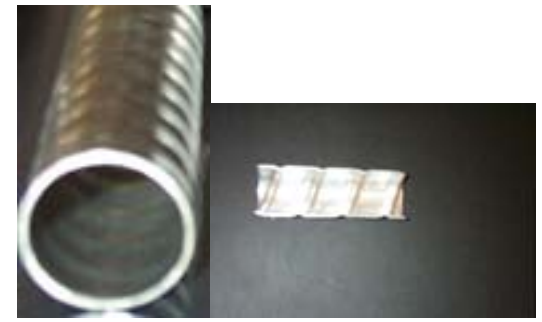

Spirally Indented Tube

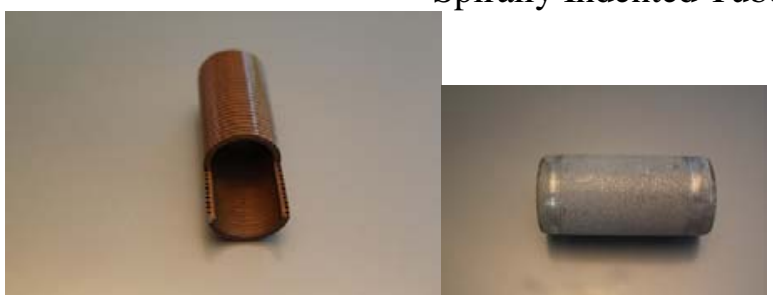

Micro-Fin Tubes and Porous Surface for Enhanced Thin-Film Evaporation and Condensation

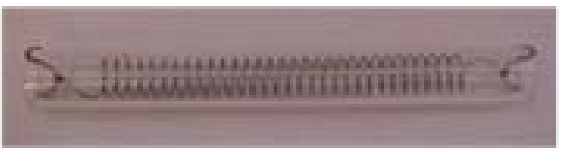

Tube inserts

Figure 3. Enhanced Tubes and Tube Inserts 


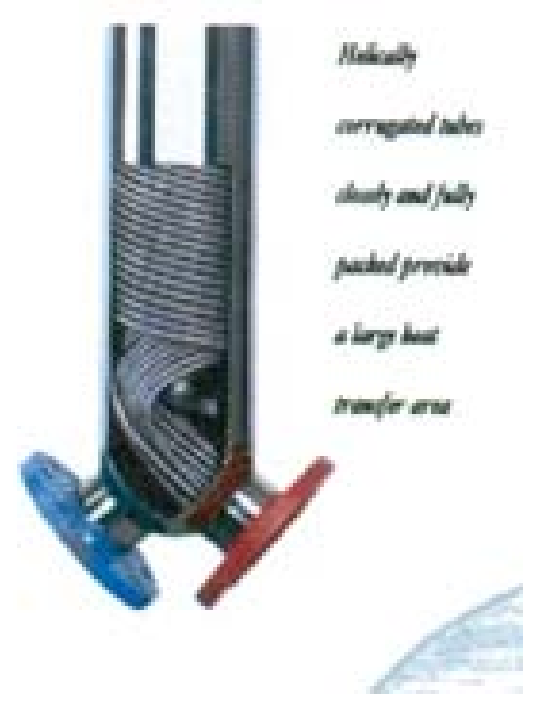

Figure 4. Shell and coil heat exchanger
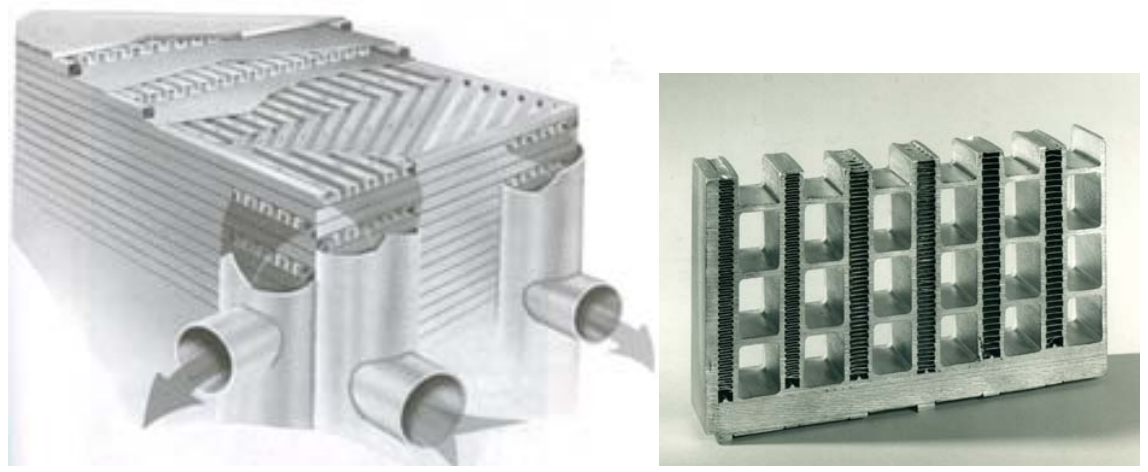

Figure 5. Section and elemental views of brazed aluminum heat exchanger 


\section{Task 5 Conceptual Designs of Heat Transfer Units for Thermally Active Trays and Packed Distillation Columns}

\subsection{Task Objective}

The purpose of this task is to develop a conceptual design for a heat-transfer unit for thermally active distillation trays and packed columns. The latent heat recovered from overhead condenser can be transferred to internal reboiler using thermally active trays and packed columns. Candidate heat transfer units include: 1) compact platefin heat transfer element; 2) tubular coil of enhanced tubes; and 3) heat-transfer unit installed in down-comers. Chemical process simulation software analysis will provide optimum integration of thermal heat pump with thermally active trays and packed columns.

\subsection{Heat Integration in Distillation Process}

Figure 1 represents $\mathrm{H} 2 \mathrm{O} 2$ distillation process equipped with the thermal heat pump. The systems analysis shows that steam consumption is reduced from $27,844 \mathrm{lb} / \mathrm{hr}$ to $15,985 \mathrm{lb} / \mathrm{hr}$ in preheating the feed to produce vapor feed. The reboiler duty is relatively small for vapor feed. For liquid feed, reboiler duty would be high and the thermal heat pump would be configured to provide the recovered latent heat to the reboiler, as shown in Figure 2. These two configurations would have minimum impact on operation of the distillation process, if thermal heat pump is retrofitted to an existing process. A fully integrated thermal heat pump distillation process involves distributed reboiler as illustrated in Figure 3. Here, the latent heat from the overhead condenser is transferred to the stripping section and also to the feed preheater. It is also possible to install internal reflux in the rectification section instead of the overhead condenser and transfer heat to the stripping section. The energy efficiency of the fully integrated thermal heat pump distillation process would be significantly improved for processes requiring separations of close-boiling mixtures, such as $\mathrm{H} 2 \mathrm{O} 2$ process of this project. Figure 4 presents heat integration of coupled distillation columns. In this process rectification and stripping sections operate at different pressures. The two columns are thermally coupled as shown in a conceptual process flow diagram, Figure 4. Here heat from distributed reflux of the rectification section is transferred to distributed reboilers in the stripping section. Detailed analysis should always be performed for selection of an optimum heat integrated distillation configuration.

Mix et al (1980) and Humphrey et al (1992) provide comprehensive analyses of energy consumptions in the process industry and opportunities for significant energy efficiency improvements, including heat integration. Analyses have shown that distributed reboiler and reflux significantly increase the overall energy efficiency of the distillation process and/or improve the separation efficiency (Budiman and Ishida, 1998). The opportunities for significant energy efficiency improvements with heat Integrated Distillation Columns (HIDiC) are being actively pursued and can be achieved as demonstrated by Ohe (2007). Santos-Mendez et al (1997) analyzed thermally coupled distillation using a dynamic simulation and showed that $40 \%$ improvements in energy efficiency is achievable without additional control problems. The process analysis by Reid (1999) demonstrated energy saving potential by application of external side reboilers and condensers for olefin and natural gas liquid (NGL) separations. In order to take full advantages of heat integration, with or without thermal heat pumps, it is essential to develop innovative thermally active distillation trays and packed columns, which is the primary focus of the task in this project.

\subsection{Heat Transfer Units}

Candidate heat transfer units include: 1) compact plate-fin heat transfer element; 2) tubular coil of enhanced tubes; and 3) heat-transfer unit installed in down-comers. Figure 5 shows a sectional view of a brazed plate-fin heat exchanger that could be integrated into sieve trays and packed columns. Brazed aluminum plate-fin heat exchangers are commonly used in cryogenic air separations. With the recent developments of nickel brazing of steel and diffusion bonding, plate-fin heat exchangers provide promising heat transfer unit. Figure 6 shows some of the commercial enhanced tubes, including spirally indented, axial fins, spiral fins, spirally fluted and twisted tubes. These enhanced tubes can be formed in proper shapes for integration with trays or packed columns. Selection of enhancement depends on heating or cooling media and single phase or two-phase (boiling or condensation) heat transfer. It is essential that heat transfer units should not adversely impact the two-phase flow fluid dynamic of trays and packed columns. Some of the key requirements considered in developing design concepts of heat transfer units are as follows. 
Sieve Trays

$>$ No significant increase in flow resistances to cross-flow of vapor and liquid phases;

$>$ Does not produce liquid bypass that would reduce the tray efficiency; and

$>$ Minimize vibration that can cause mechanical damage to trays and internal supports.

Packed Columns

$>$ No significant increase in flow resistances to counter vertical flows of vapor and liquid phases;

$>$ Does not induce liquid maldistribution that would reduce the column efficiency; and

$>$ Minimize vibration that can cause mechanical damage to packings and internal supports.

Integration of Heat Transfer Units within Distillation Trays

Thermally active trays are being considered for selective applications. For commercial distillation processes, where large diameter columns are used, four design concepts are developed in this project.

a. Helically coiled tubes

b. Serpentine enhanced tubes

c. Brazed or diffusion bonded plate-fin

d. Tube bundle or plate-fin unit installed in down comers

Helically Coiled Tubes: In this design concept plain or enhanced tubes are coiled and laid on trays. If necessary helical coils can be mounted some distance above tray, with appropriate support structure. Each coiled tube is connected to headers at both ends. Headers can be individually connected at inlet/outlet nozzles or a vertical distribution pipes can be used to connect headers from other trays equipped with heat transfer units. The process fluid flows parallel to the axis of helical coils to minimize hydraulic gradient between inlet and outlet downcomers. If hydraulic gradient is not a limitation, helical coils could be mounted for cross flow that would provide more effective heat transfer. In both concepts helical coils do not introduce significant pressure drop to the vapor flow.

Serpentine Enhanced Tubes: Serpentine tubes can be used instead of helically coiled tubes. Enhanced tubes, such as Twisted Tubes ${ }^{\circledR}$ with or without microfins on outside, can be formed in serpentine shapes. Depending on liquid loading of the tray, multiple rows can be mounted with individual tube rows supported by cross bars. The overall configuration gives cross flow of fluid and care should be taken in tube spacing to minimize hydraulic resistance. Tubes can be arranged in triangular or square pattern, depending on fluid velocity and corresponding hydraulic gradient.

Brazed or Difusion Bonded Plate-Fin: Brazed plate-fin heat transfer units, similar to the elemental section shown in Figure 5, can be installed on sieve trays. Fins are configured to allow cross flow of fluid on the tray, while vapor rises through the tray. Downcomer Unit: Installing heat transfer unit in downcomers is an effective way of integrating heat transfer unit in trays. Figure shows a conceptual design of heat transfer unit in a concentric downcomer. The heat transfer unit could be tube bundle using appropriate enhanced tubes, Figure 6, or brazed plate-fin configuration. Here the process fluid is cooled as it flows down from a tray to the tray below; therefore, the heat transfer unit does not interfere with two-phase flows on the tray. Care should be taken to minimize pressure drop so that liquid holdup on the tray is not adversely affected.

\subsection{Integration of Heat Transfer Units into Packed Columns}

Heat integration of packed columns is more difficult than trays due to complex counter-current liquid and vapor flows. However, the two concepts of thermally active packed columns described here could be integrated in structured packed columns without affecting the two-phase flow pattern.

Coiled Tubes: Structured packings can be installed between serpentine coils. This configuration provides effective

contact of liquid or vapor phase with heat transfer unit, depending on reboiler or reflux heat duty without adversely affecting the counter two-phase flow pattern. The heat transfer unit would have adequate structural support for the weight of packing sections and other column accessories.

Brazed or Diffusion Bonded Plate-Fin: In this conceptual design, structured packings would be sandwiched between platefin heat transfer flow channels. The heat transfer unit is then either brazed or diffusion bonded depending on materials. . 
This design concept provides an effective heat transfer without impacting the counter flow of vapor and liquid phases. Similar to the coiled-tube configuration, plate-fin heat transfer unit can be integrated into packed columns as a section between structured packing sections.

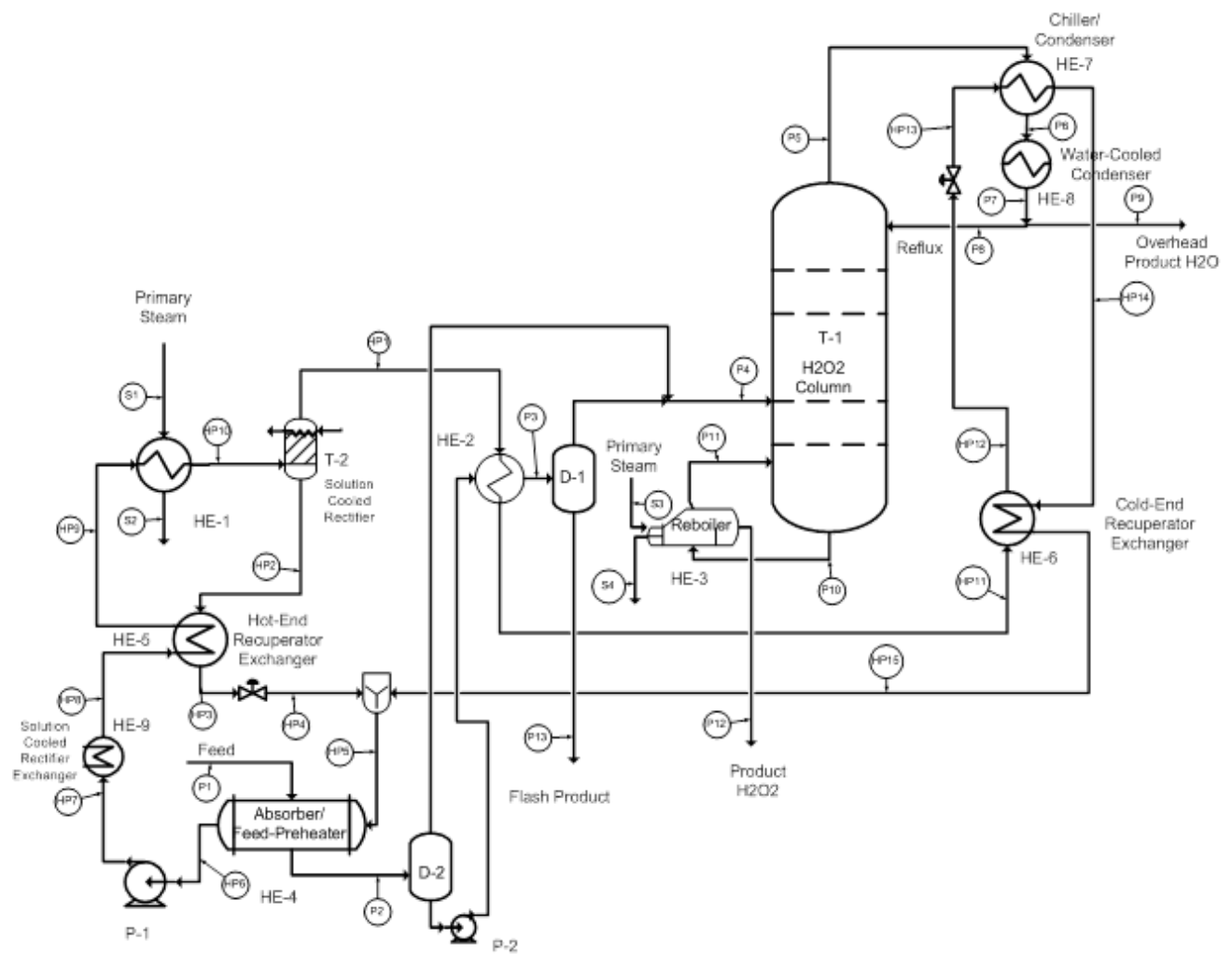

Figure 1. PFD of H2O2 distillation with vapor feed equipped with thermal heat pump

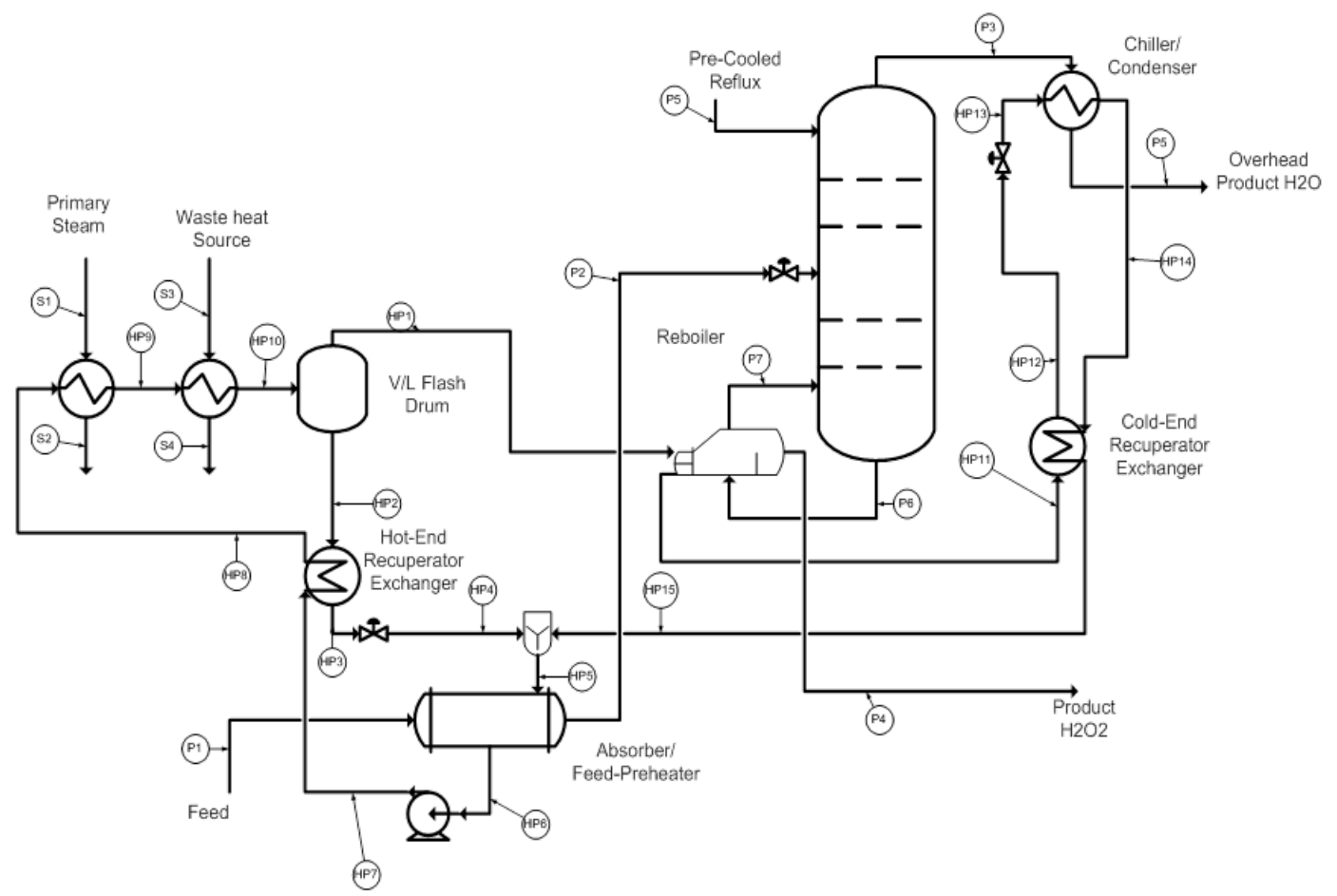

Figure 2. PFD of H2O2 distillation with liquid or two-phase feed equipped with thermal heat pump 


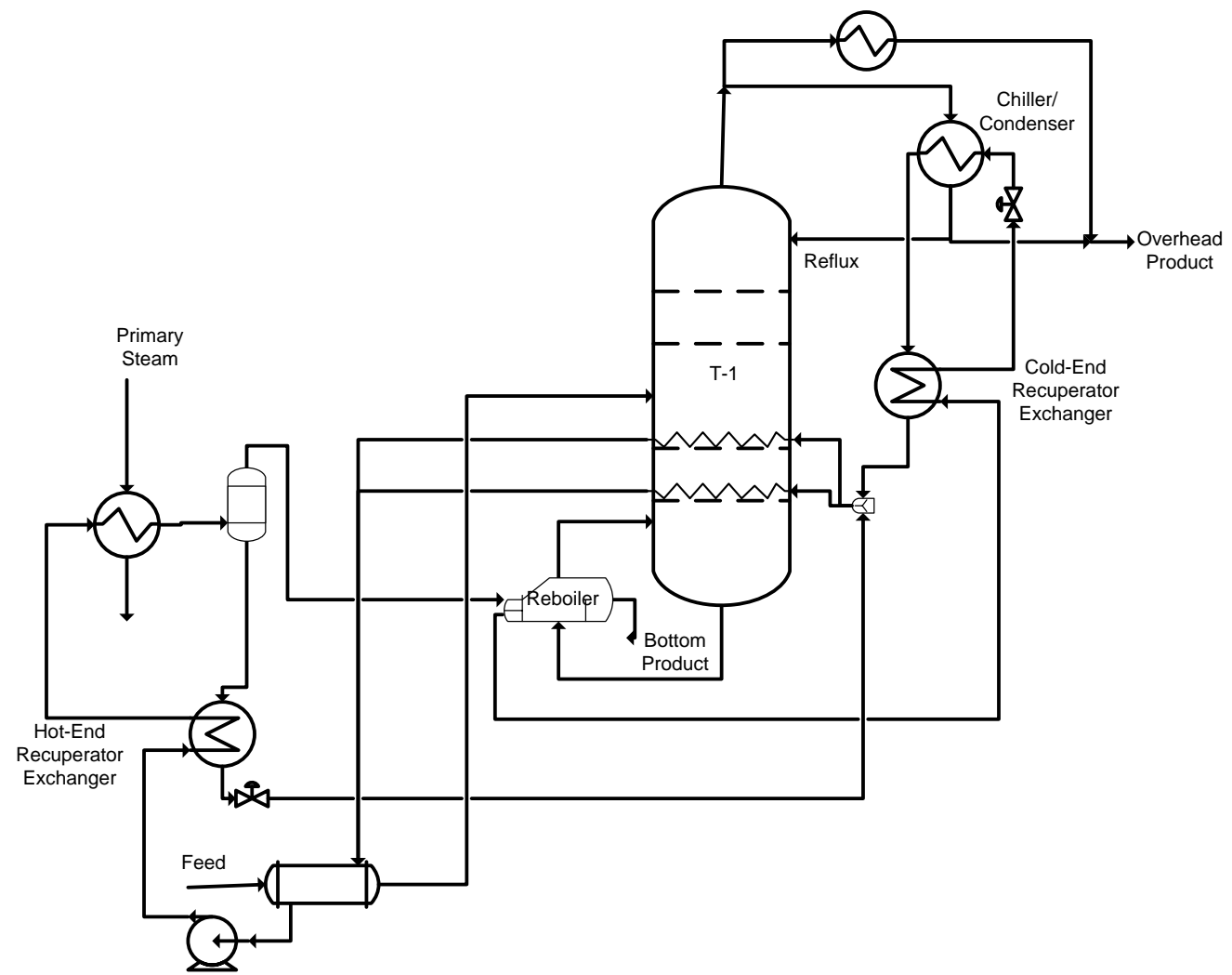

Figure 3. Distillation Process equipped with Distributed Reboiler Thermal Heat Pump

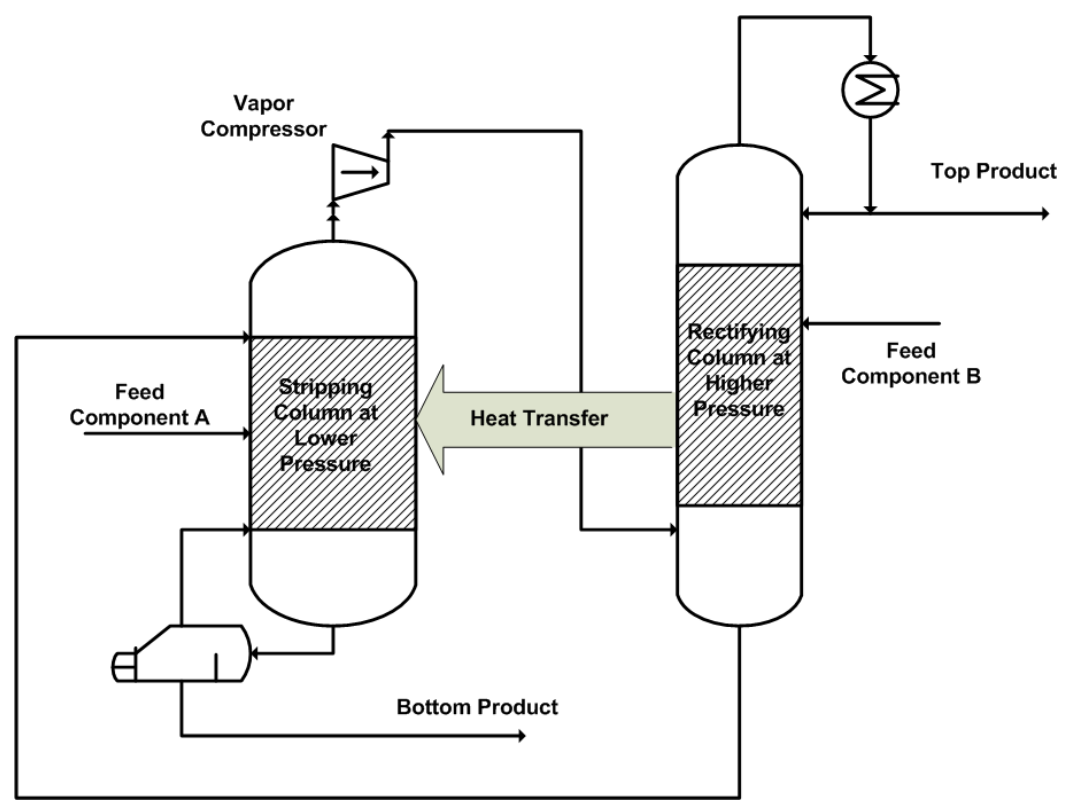

Figure 4. Thermally coupled columns 


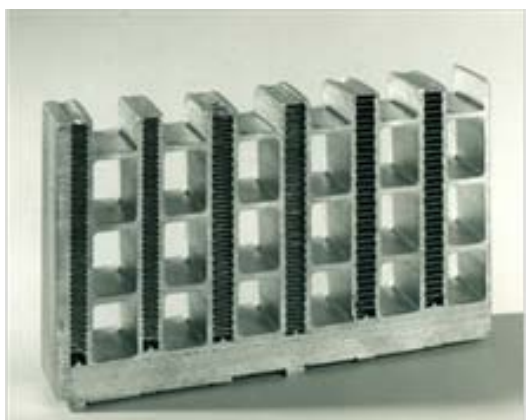

Figure 5. Brazed plate-fin heat transfer unit

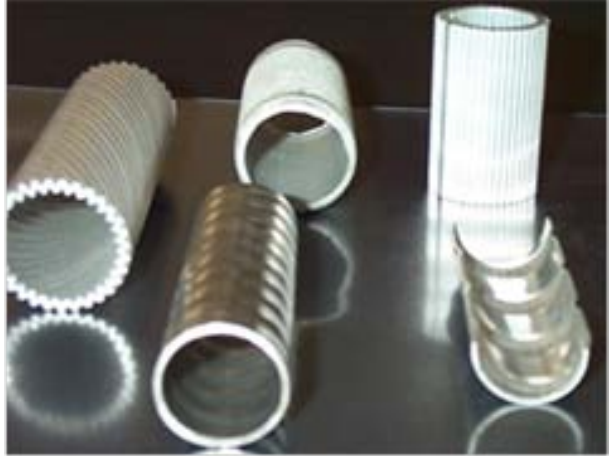

Figure 6. Enhanced tubes 


\section{Task 6: Commercialization Plan}

The objectives of Task 6 focused on technical, economic and policy issues for commercialization of this technology and economic analysis on the profitability of the technology. Also in this task, major barriers were identified and the project team suggested a path forward plan to overcome these barriers.

\subsection{Payback Period Analysis:}

We performed an economic analysis for estimating the payback period for two cases: a) TEE open cycle system Heat Pump, and b) the H2O2 Distillation cycle Heat Pump waste heat recovery processes. The payback periods calculated did not include process improvements, which would have otherwise enhanced the attractiveness of this technology. Another barrier in improving the economics of these processes, is the constraint we faced on not been able to increase the production capacity of the existing processes. Also, it is not feasible to take credit for environmental benefits on carbon dioxide emission. In particular, for the TEE closed system Heat Pump, there were many process constraints to retrofit the HP to the existing TEE that could not be achieved especially the constraint on the required rate of vapor generation from each effects. Also for this system, we could not optimize the Aspen plus process analysis work. The payback period for this system was anticipated to be much worse than the TEE open system and consequently we do not think it was worthwhile to proceed on detail calculations on the payback period and equipment cost. To that extent, the payback period analysis for the TEE closed cycle system Heat Pump is not included in this report.

We estimated the major equipment costs for both MEE open system and H2O2 distillation waste heat pump systems. However, it is difficult to estimate the cost of interfacing the HP with the existing systems. For the H2O2 distillation waste heat pump system, there is a need for a pilot plant to validate the estimated fixed capital costs based on some cost factors as detailed below. On the other hand, based on the long payback period for the TEE system, the use of additional resources to validate the capital costs by completing a more refined estimate is not warranted unless there are future significant improvements to the heat pump technology.

The payback period is calculated as the number of years to recover the fixed capital income expended assuming constant annual combined steam and cooling water savings. The estimated fixed capital costs, major equipment cost and payback periods for the two systems are summarized in Table 6.1

Table 6.1 Estimated Payback Periods for the Heat Pump Waste Heat Recovery Systems

\begin{tabular}{|l|l|l|l|l|l|}
\hline $\begin{array}{l}\text { Thermal Heat } \\
\text { Pump System }\end{array}$ & $\begin{array}{l}\text { Major Equipment } \\
\text { Cost, \$K }\end{array}$ & $\begin{array}{l}\text { Estimated Fixed } \\
\text { Capital Cost, \$K }\end{array}$ & $\begin{array}{l}\text { Steam Savings, } \\
\text { \$K/Yr }\end{array}$ & $\begin{array}{l}\text { Cooling Water } \\
\text { Savings, \$K/Yr }\end{array}$ & $\begin{array}{l}\text { Payback Period, } \\
\text { Years }\end{array}$ \\
\hline $\begin{array}{l}\text { H2O2 Distillation } \\
\text { NH3-H2O } \\
\text { System }\end{array}$ & 688 & 4133 & 748 & 85 & 5.0 \\
\hline $\begin{array}{l}\text { TEE Open } \\
\begin{array}{l}\text { System using } \\
\text { Nitrates Solution }\end{array}\end{array}$ & 928 & 6135 & 312 & 0 & 19.7 \\
\hline
\end{tabular}




\subsubsection{TEE Open System Heat Pump Waste Heat Recovery System}

The TEE open system heat pump waste heat recovery system considered uses alkaline nitrate (NO3)-nitrite (NO2) working fluid. From the detailed Aspen plus simulation results we carried out for this system as reported in previous quarterly reports, the major equipment were sized and the cost were estimated as shown in Table 6.1.1

Table 6.1.1 Major Equipment Cost Estimate for the TEEOpen Cycle Thermal Heat Pump

\begin{tabular}{|c|c|c|c|c|c|}
\hline Tag & Equipment & Description & $\begin{array}{c}\text { Area } \\
\text { ft2 }\end{array}$ & $\begin{array}{c}\text { Material } \\
\text { Tubes/Shell }\end{array}$ & $\begin{array}{c}\text { Estimated } \\
\text { Cost } \\
\$\end{array}$ \\
\hline D-1 & V/L Separator & $\begin{array}{l}\text { 5ft (diam), } 15 \mathrm{ft} \text { (length), } 2000 \\
\text { gallons } 316 \text { SL with Demister, } \\
50 \text { psia }\end{array}$ & & & 70,000 \\
\hline HPP-1 & Circulation Pump & $\begin{array}{l}130 \text { gpm , } 316 \text { L Stainless Steel } \\
\text { reciprocating pump, } 4.2 \text { HP }\end{array}$ & & & 6,000 \\
\hline HE-1 & Vapor Generator & Shell and tube - Twisted Tubes & 2285 & $\begin{array}{c}\text { SS 316L/SS } \\
\text { 316L }\end{array}$ & $\$ 302,090$ \\
\hline $\mathrm{HE}-4$ & $\begin{array}{l}\text { Absorber/Feed } \\
\text { Preheater }\end{array}$ & Shell and tube - Twisted Tubes & 3704 & $\begin{array}{c}\text { SS 316L/SS } \\
\text { 316L }\end{array}$ & $\$ 523,000$ \\
\hline HE-5 & Hot-End Recuperator & Welded Plate - stainless steel & 261 & SS 316L & $\$ 26,460$ \\
\hline & & & & Total & $\$ 927,550$ \\
\hline
\end{tabular}

The fixed capital for the TEE open cycle thermal heat pump is estimated from the major equipment cost in Table 6.1.1, using cost factors from design guidelines for installation and a 30\% contingency. The resulting total installed cost is $\$ 6.14$ million. The steam savings is calculated from the reduction of steam usage with the interfaced heat pump. For the benchmark case (with no HP), the TEE system used 119,882lb/hr of 37.5 psia steam whereas with the HP, the system used 56,249 lb/hr of 37.3 psia and 44,053 lb/hr of 162.7 psia steam. Based on an incremental variable cost of steam at our plant location, the steam savings is estimated as \$312,000.00 per year. For this TEE open cycle system at FMC location, savings from reduction in cooling water load by the HP is considered not significant at the plant location and was not included in estimating the payback period. The payback period is therefore estimated to be 19.7 years calculated from the number of years required to recover the fixed capital cost assuming constant annual steam savings. 


\subsubsection{H2O2 Distillation Heat Pump Waste Heat Recovery System}

The H2O2 distillation heat pump waste heat recovery system considered uses ammonia-water working fluid. From the detailed Aspen plus simulation results we carried out for this system as reported in previous quarterly reports, the major equipment were sized and the cost were estimated as shown in Table 6.1.2

Table 6.1.2 Major Equipment Cost Estimate for the H2O2 Distillation Cycle Thermal Heat Pump

\begin{tabular}{|c|c|c|c|c|c|}
\hline Tag & Equipment & Description & $\begin{array}{c}\text { Area } \\
\text { ft } 2\end{array}$ & $\begin{array}{c}\text { Material } \\
\text { Tube/Shell }\end{array}$ & $\begin{array}{c}\text { Estimated } \\
\text { Cost } \\
\$\end{array}$ \\
\hline HE-1 & $\begin{array}{l}\text { Ammonia Vapor } \\
\text { Generator }\end{array}$ & $\begin{array}{l}\text { Shell and tube - } \\
\text { Twisted Tube }\end{array}$ & 749 & $\mathrm{CS} / \mathrm{CS}$ & $\$ 89,520$ \\
\hline HE-2 & Feed Heater & $\begin{array}{l}\text { Shell and tube - } \\
\text { Twisted Tube }\end{array}$ & 473 & $\mathrm{CS} / \mathrm{CS}$ & $\$ 65,800$ \\
\hline HE-3 & Reboiler & Existing & & & \\
\hline HE-4 & $\begin{array}{l}\text { Ammonia } \\
\text { Absorber/Feed } \\
\text { Preheater }\end{array}$ & $\begin{array}{l}\text { Shell and tube - } \\
\text { Twisted Tube }\end{array}$ & 2019 & CS/CS & $\$ 173,970$ \\
\hline HE-5 & $\begin{array}{l}\text { Hot-End } \\
\text { Recuperator }\end{array}$ & $\begin{array}{l}\text { Welded Plate - } \\
\text { stainless steel }\end{array}$ & 313 & SS 316L & $\$ 31,740$ \\
\hline HE-6 & $\begin{array}{l}\text { Cold-End } \\
\text { Recuperator }\end{array}$ & Shell and Coil & 734 & SS 316L/CS & $\$ 36,700$ \\
\hline HE-7 & Chiller/Condenser & $\begin{array}{l}\text { Shell and tube - } \\
\text { Twisted Tube }\end{array}$ & 887 & $\mathrm{CS} / \mathrm{CS}$ & $\$ 100,260$ \\
\hline HE-8 & $\begin{array}{l}\text { Water Cooled } \\
\text { Condenser }\end{array}$ & Existing & & & \\
\hline HE-9 & $\begin{array}{l}\text { Solution Cooled } \\
\text { Rectifier } \\
\text { Exchanger }\end{array}$ & Part of Rectifier & & CS & \\
\hline $\mathrm{T}-1$ & $\begin{array}{l}\text { Ammonia-Water } \\
\text { Rectifier }\end{array}$ & $\begin{array}{l}\text { 2inch packings, } \\
\text { CS Tower }\end{array}$ & & & $\$ 184,000$ \\
\hline HPP-1 & Circulation Pump & $\begin{array}{l}200 \text { gpm , 316 L } \\
\text { Stainless Steel } \\
\text { reciprocating } \\
\text { pump, } 77 \mathrm{HP}\end{array}$ & & & $\$ 6,200$ \\
\hline Total & & & & & $\$ 688,190$ \\
\hline
\end{tabular}

The fixed capital for the $\mathrm{H} 2 \mathrm{O} 2$ distillation cycle thermal heat pump is estimated from the major equipment cost in Table 6.1.2, using cost factors from design guidelines for installation and a $30 \%$ contingency. The resulting total installed cost is $\$ 4.13$ million. The steam savings is calculated from the reduction of steam usage with the interfaced heat pump. For the bench mark case (with no HP), the H2O2 distillation system used about 27,844 lb/hr of steam whereas with the HP, the system used 15,985 lb/hr of steam, an 11,859 lb/hr steam savings. Based on a steam cost of $\$ 8.00$ per 
thousand pounds, the steam savings is estimated as $\$ 748,000$ per year. We have estimated a reduction of about 65,000 gallons per hour of cooling water load. Based on a cost of cooling water (make-up water + pumping power + fans power + chemical treatments) of 16.5 cents $/ 1000$ gal, the cooling water savings is estimated as $\$ 85,000$ per year. The combined steam and cooling water savings is about $\$ 833,000.00$ per year. The payback period is, therefore estimated to be 5.0 years calculated from the number of years required to recover the fixed capital cost assuming constant annual steam and cooling water savings. 


\section{Accomplishments}

The TEAM completed all the major tasks of the proposed project. The potential benefits and market assessment of the technology were completed for selected industrial processes. The TEAM identified working fluid pairs for high (or moderate) temperature heat pumps and characterization of their thermo-physical properties was formulated. The TEAM has completed the screening of alternative industrial distillation and TEE/crystallization processes for application of waste-heat powered thermal heat pumps. The Aspen + simulation of both the TEE and H2O2 distillation processes have been carried out. For $\mathrm{H} 2 \mathrm{O} 2$ distillation process, a significance steam savings of $30 \%$ to $45 \%$ over the benchmark are potentially achievable by incorporating the waste heat recovery pump closed/open system. The TEAM has completed the conceptual design of enhanced heat transfer equipment. Enhance performance of heat transfer equipment that include twisted tubes, spirally fluted tubes, and heat compact heat exchangers have been investigated. And the TEAM has also completed conceptual design of a heat-transfer device for thermally active distillation trays and packed columns.

The commercialization plan task focused on the economics of waste heat recovery in the TEE and H2O2 heat pump systems. There were several process constraints in retrofitting into the existing soda ash TEE process. As a result, the payback period was estimated to be 19 years for the TEE open cycle system heat pump, which is not encouraging. Due to the long payback period estimated for the TEE system, further studies on the TEE system are not warranted unless there are significant future improvements to heat pump technology. For the $\mathrm{H} 2 \mathrm{O} 2$ distillation cycle heat pump waste heat recovery system, there were no significant process constraints and the estimated 5 years payback period is encouraging. This estimate may become more attractive through pilot plant tests to validate the results and remove the uncertainty factors included in this estimate for $\mathrm{H} 2 \mathrm{O} 2$ system. 


\section{Conclusions}

Distillation, TEE and crystallization are widely used in petroleum, chemical, food processing, and pulp \& paper industries. In addition, increased production of fuel-grade ethanol requires energy efficient distillation and TEE for favorable netenergy balance of ethanol. All these processes will benefit from the development of waste-heat powered thermal heat pump and thermally active trays and packed columns. With aggressive industry-wide applications of heat recovery and recycling with absorption heat pumps, energy savings of 26.7 trillion Btu/yr are possible for distillation processes. The direct environmental benefits for this project are the reduced emissions of combustible products and reduced consumption of fresh water. The estimated major reduction in environmental pollutants in the distillation processes is in CO2 emission equivalent to 3.5 billion lbs/year. Energy consumption associated with water supply and treatments can vary between 1,900 $\mathrm{kWh}$ and 23,700 kWh per million-gallon water depending on sources of natural waters [US DOE, 2006]. And by reducing the demand for cooling tower waters, this project will significantly reduce the use and discharge of water treatment chemicals.

Some barriers and difficulties were encountered in carrying out this project. Among which for the soda ash TEE process, there were constraints from making changes to the current vaporization rates from the each of the effects. Although carbon steels are commonly used for the ammonia-water absorption refrigeration systems, for excellent performance, air has to be removed at startup and after normal maintenance. We anticipate that it will be okay to use carbon steel for the piping/equipment for the ammonia/water except for the sections where the ammonia/water heat pump system interface with the $\mathrm{H} 2 \mathrm{O} 2$ distillation system like the heat exchangers units HE-2 and HE-4. This is to avoid potential explosion that will result from any contact between hydrogen peroxide and carbon steel. The Ammonia-Water Rectifier (T-1) was provided for the separation of the ammonia/water stream into a relatively pure ammonia stream using 10' of 2" SS packing for improved thermodynamic efficiency requiring no reboiler which is equivalent to a flashed stream from the vaporizer. Some of the heat exchanger designs in this project were very difficult including consideration for the partial vaporization of many of the streams. In particular, our design methods for the $\mathrm{H} 2 \mathrm{O} 2$ distillation system were based on previous design of heat TwistedTube heat exchangers for ammonia-water absorption refrigeration system using an in-house design algorithms that is based on calculation of individual heat transfer coefficients and the hence the overall average heat transfer coefficient of the unit. Also, Hydrogen Peroxide distillation is a vacuum distillation, and all vacuum distillations leak air into the process. The presence of air or other non-condensable gases is a common problem with most of vacuum condensers which lowers the condenser temperature costing performance (back-pressure) and/or parasitic penalties. With proper design of an alternate condenser, the proposed use of vaporizing ammonia in the condenser should help in managing non-condensable gases. The project design basis for the first installation is to retrofit the column without impacting the operation. This retrofit approach would also allow returning to normal operation, in case the thermal heat pump needs maintenance or shuts down for any reason. With operating experience with the thermal heat pump, the subsequent installations can be more integrated, including the reboiler and/or a distributed reboiler. Installation of high-performance heat exchangers for heat recovery and absorption heat pumps can be readily accomplished during normal turnaround. Therefore, market penetration should not be difficult as part of a routine retrofit in the chemical and refining industries.

Overall, we have completed all the major tasks in this project. In particular, we have identified and characterized workingfluid pairs for high temperature industrial applications typical of thermal separation processes and completed the conceptual design of enhanced heat transfer equipment that includes twisted tubes, spirally fluted tubes, and compact heat exchangers for the TEE process. We have also completed the conceptual design for a heat-transfer device for thermally active distillation trays and packed columns. We believe that the enhanced heat transfer equipment has the potential to significantly improve the performance of TEE crystallizers, independent of the absorption heat recovery system. In other locations where steam costs are high, a more detailed design/cost engineering study could be beneficial to investigate the economic viability of the technology. 


\section{Recommendations}

For the TEE, systems and economic analyses are required for technical and economic viability of application of heat exchangers equipped with the state-of-the-art enhancements. A prototype unit should be considered for validating enhanced thermal performances of heat transfer equipment and evaluating fouling characteristics in field testing. For the H2O2 system, though several generic system analysis have been performed for distributed reboiler and reflux in distillation columns, a detailed process analysis for one or two specific industrial processes should be considered to quantify the energy efficiency improvements and identify complexity of integration. A prototype integrated heat transfer unit should be considered for validation of performance and development of prediction methods. From our analysis of H2O2 HP system, thermally active trays and packed columns are expected to improve stability of the operation and maintaining the column performance at optimum conditions under varying process and utility (heating steam pressure and cooling water temperatures or flows) conditions. Therefore, a dynamic analysis should be further considered for evaluation of a control strategy using thermally active trays and packed columns. These analyses should be followed by an economic analysis based on life-cycle costs.

Due to the long payback period estimated for the TEE system, further studies on the TEE system are not warranted unless there are significant future improvements to heat pump technology. For the $\mathrm{H} 2 \mathrm{O} 2$ distillation cycle heat pump waste heat recovery system, there were no significant process constraints and the estimated 5 years payback period is encouraging. We therefore recommend further studies for the $\mathrm{H} 2 \mathrm{O} 2$ distillation process to define the technical and economic viability of heat exchangers equipped with the state-of-the-art enhancements. This will require additional funding for a prototype unit to validate enhanced thermal performances of heat transfer equipment, evaluate the fouling characteristics in field testing, and remove the uncertainty factors included in the estimated payback period for the hydrogen peroxide distillation system. 


\section{References/Bibliography}

Alvarez M, Bourouis M, and Esteve X, "Vapor-Liquid Equilibrium of Aqueous Alkaline Nitrate and Nitrite Solutions for Absorption Refrigeration Cycles with High-Temperature Driving Heat,” J. Chem. Eng. Data, Accepted for Publication, 2011.

Boesmann A and Schubert T, "Novel Pairs of Working Substances for Absorption Heat Pumps, Absorption Refrigeration Machines and Heat Transformers," US Patent 2008/0028777 A1, 2008.

Bokelmann H, and Steimle F, “Development of Advanced Heat Transformers Utilizing New Working Fluids,” Rev. Int. Froid, 9, 1986.

Budiman A and Ishida M, 1998, “Optimal Side Heating and Cooling in a Distillation Column,” Energy, vol, 5, 365-372.

Butterworth D and Mascone C, 1991, "Heat Transfer Lead into $21^{\text {st }}$ Century,” Chem. Eng. Prog., September.

Humphrey JL and Seibert AF, 1992,”Separation Technologies: An Opportunity for Energy Savings”, Chemical Engineering Progress, March 1992.

Jafari Nasr MR and Polley G, 2002, “Should You Use Enhanced Tubes,” Chem. Eng. Prog., April.

Kim K-S, Shia B-K, Lee H, and Ziegler F, "Ionic Liquids as New Working Fluids for use in Absorption Heat Pumps or Chillers,” Internet Search, 2010.

Macriss RA and Zawacki TS, “Absorption Fluid Data Survey: 1989 Update,” Oak Ridge National Laboratory Report, ORNL/Sub/84-47989/4, 1989.

Mix TW, Dweck JS, Weinberg M, and Armstrong RC, “Energy Conservation in Distillation,” Recent Advances in Separation Techniques - II; vol 76, AIChE Symposium Series 192.

Ohe S, 2007, “Energy-Saving Distillation through Internal Heat Exchange (HIDiC),” AIChE Distillation 2007, Topical Conference Proceedings, 2007 Spring Meeting, Houston, TX.

Panchal CB and Ljubicic B, 2008, "Design Approach for Mitigating Fouling of Reboilers and Feed/Effluent Heat Exchangers," Proceedings of the AIChE Spring Meeting, New Orleans, LA.

Panchal CB, Malone P, Stomeirowski S, and Cao T, 2004, "Mitigation of Crude Oil Fouling by Tube Inserts and Enhanced Tubes," Proceedings of the AIChE Spring Meeting, New Orleans, LA.

Panchal CB and Rabas TJ, 1993, "Thermal Performance of Advanced Heat Exchangers for Ammonia Refrigeration Units," $J$ of Heat Transfer Eng., vol. 14.

Panchal CB, Vega L, and Bell KJ, "Plate-Fin Condenser for Condensaiton of Low Pressure Steam in the Presence of Noncondensable Gases, Compact Heat Exchangers for the Process Industry, Begell House Publishing, New York, NY 1997.

Rabas TJ, Panchal CB, Sasscer DS, and Schaefer R, 1993, “Comparison of River-Water Fouling Rates for Spirally Indented and Plain Tubes,” J of Heat Transfer Eng., vol. 14.

Reid JA, 1999, “Application of Side Condensers and/or Reboilers for Olefins and NGL Units,” AIChE Proceedings: Distillation - Horizons for the New Millennium, AIChE Spring National Meeting, Houston, TX.

Santos-Mendez J and Hernandez S, 2007, "Effect of Recycle Streams on the Closed Loop Dynamics of Thermally Coupled Distillation Sequences,” AIChE Distillation 2007, Topical Conference Proceedings, 2007 Spring Meeting, Houston, TX.

Vargas P, Salavera D, Galleguillos, and Coronas A, "Solubility of Aqueous Mixtures of Alkaline Nitrates and Nitrites Determined by Differential Scanning Calorimetry,” J. Chem., Eng. Data, 53, 2008.

Wadekar V, 2000, “Compact Heat Exchangers,” Chem. Eng. Prog., December.

Zhuo CZ and Machielsen CHM, "Performance of High-Temperature Absorption Heat Transformers using Alkitrate as the Working Pair,” Applied Thermal Engineering, 16, 1996. 